
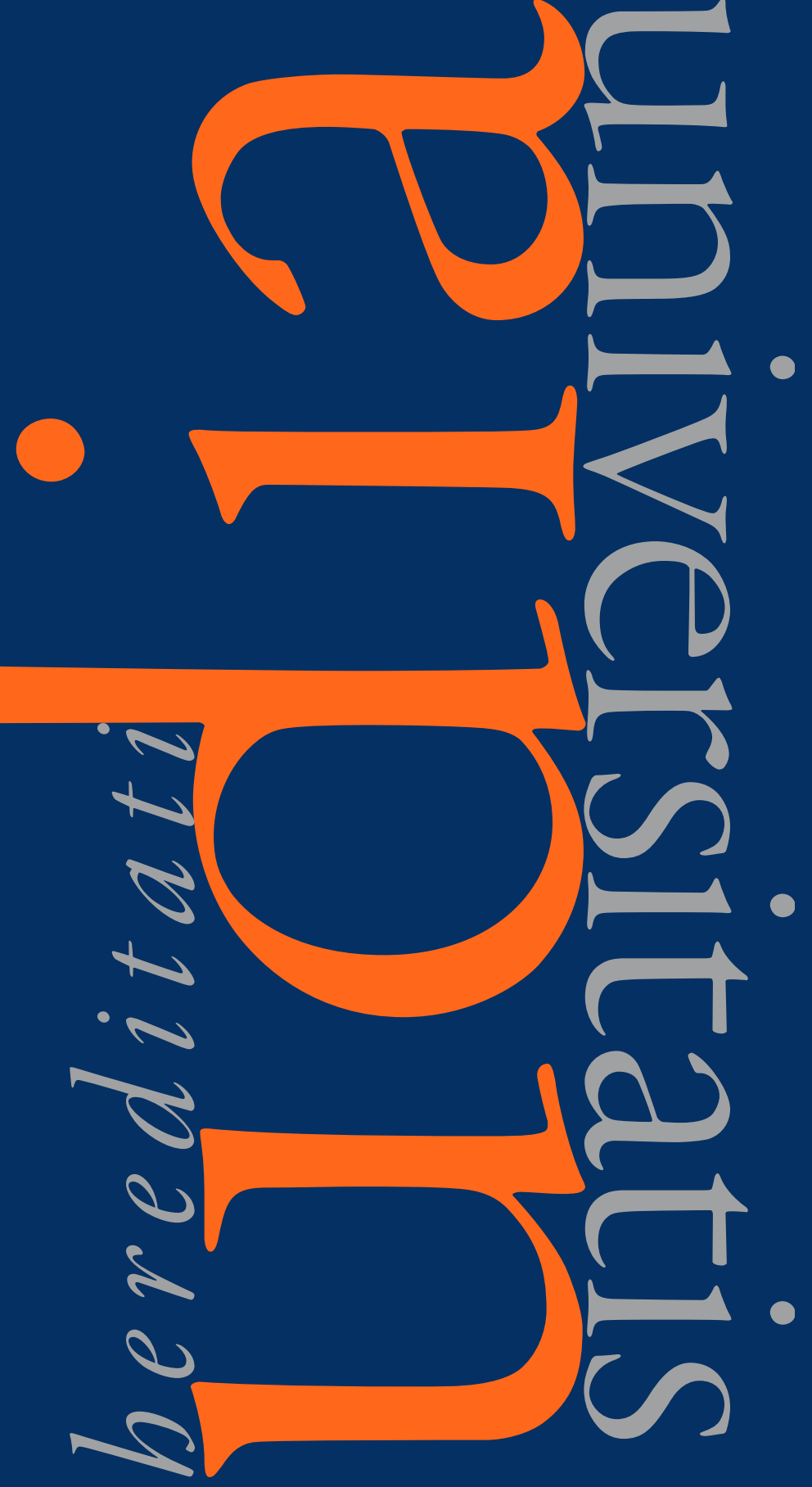

LETNIK 3

ŠTEVILKA 2

LETO 2015
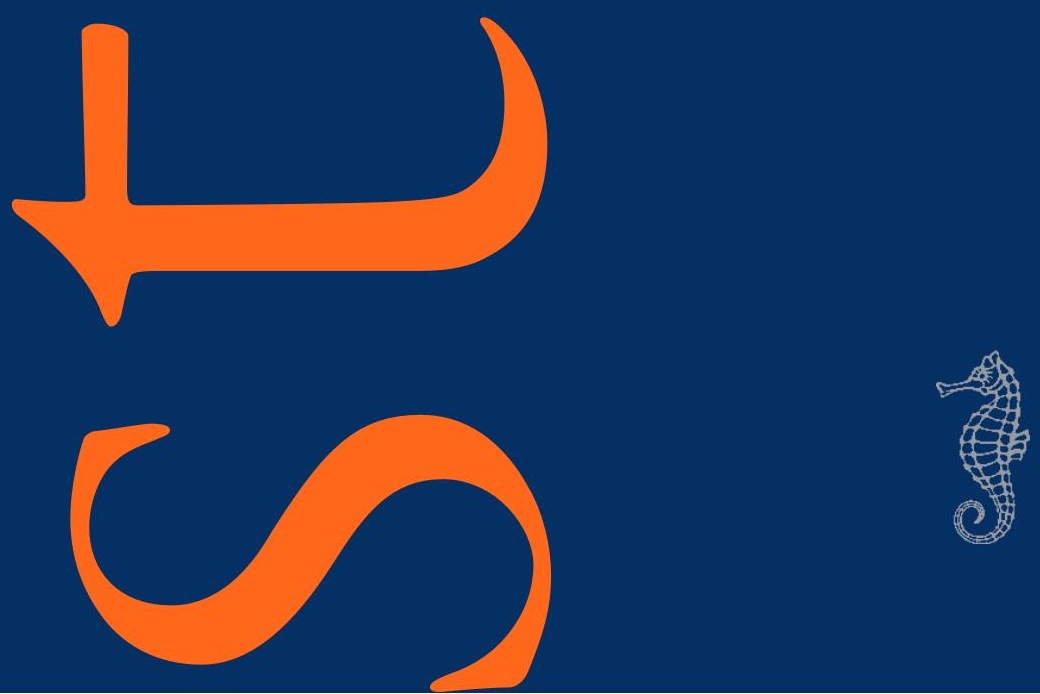


\section{STUDIA UNIVERSITATIS HEREDITATI}

Znanstvena revija za raziskave in teorijo kulturne dediščine

Letnik 3, številka 2, 2015

Studia universitatis hereditati je humanistična znanstvena revija za raziskave in teorijo kulturne dediščine z mednarodnim uredniškim odborom. Objavlja znanstvene in strokovne članke s širšega področja kulturne dediščine (arheologija, arhitektura, etnologija, jezikoslovje, literarna, kulturna, glasbena, intelektualna, religijska, vojaška zgodovina, zgodovina idej itn.) in pregledne članke ter recenzije tako domačih kot tujih monografij z omenjenih področij. Revija izhaja dvakrat letno. Izdajata jo Fakulteta za bumanistične studije (Oddelek za arheologijo in dediscino) in Založba Univerze na Primorskem.

Poglavitni namen revije je prispevati k razvoju raziskav kulturne dediščine v najširšem in k topoglednemu interdisciplinarnemu pristopu $\mathrm{k}$ teoretičnim in praktičnim raziskovalnim vprašanjem. Tako revija posebno pozornost namenja razvoju slovenske znanstvene in strokovne terminologije, konceptov in paradigem na področju raziskovanja kulturne dediščine v okviru humanističnih ved.

\section{Glauni in odgovorni urednik}

dr. Gregor Pobežin (Fakulteta za humanistične študije Univerze na Primorskem, Koper) Tehnična ureditev revije, oblikovanje in prelom

dr. Jonatan Vinkler (Fakulteta za humanistične študije, Univerza na Primorskem, Koper)

Lektor (slovenska besedila)

Davorin Dukič (Univerza na Primorskem, Koper)

\section{Uredniski odbor}

dr. Zdravka Hincak (Filozofski fakultet, Sveučilište u Zagrebu), dr. Matej Hriberšek (Filozofska fakulteta, Univerza v Ljubljani), dr. Katja Hrobat Virloget (Znanstveno-raziskovalno središče Univerze na Primorskem, Koper), dr. Irena Lazar (Fakulteta za humanistične študije Univerze na Primorskem, Koper), dr. Maša Sakara Sučevič (Pokrajinski muzej, Koper), dr. Alenka Tomaž (Znanstveno-raziskovalno središče Univerze na Primorskem, Koper), dr. Tomislav Vignjevič (Fakulteta za humanistične študije Univerze na Primorskem, Koper), dr. Jonatan Vinkler (Fakulteta za humanistične študije Univerze na Primorskem, Koper), dr. Paola Visentini (Museo Friulano di Storia Naturale, Udine)

Izdajatelj: Univerza na Primorskem - Založba Univerze na Primorskem (za Fakulteto za humanistične študije Univerze na Primorskem)

(C) 2015 Založba Univerze na Primorskem

Zanjo: prof. dr. Dragan Marušič, rektor

Titov $\operatorname{trg} 4$

SI-6000 Koper

ISSN $2350-5443$

DOI: https://doi.org/10.26493/2350-5443.3(2)

\section{(c) (1) $(9)$


studia universitatis hereditati 



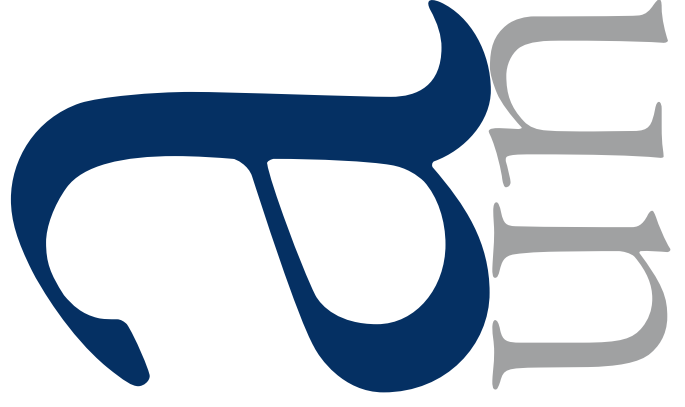

○
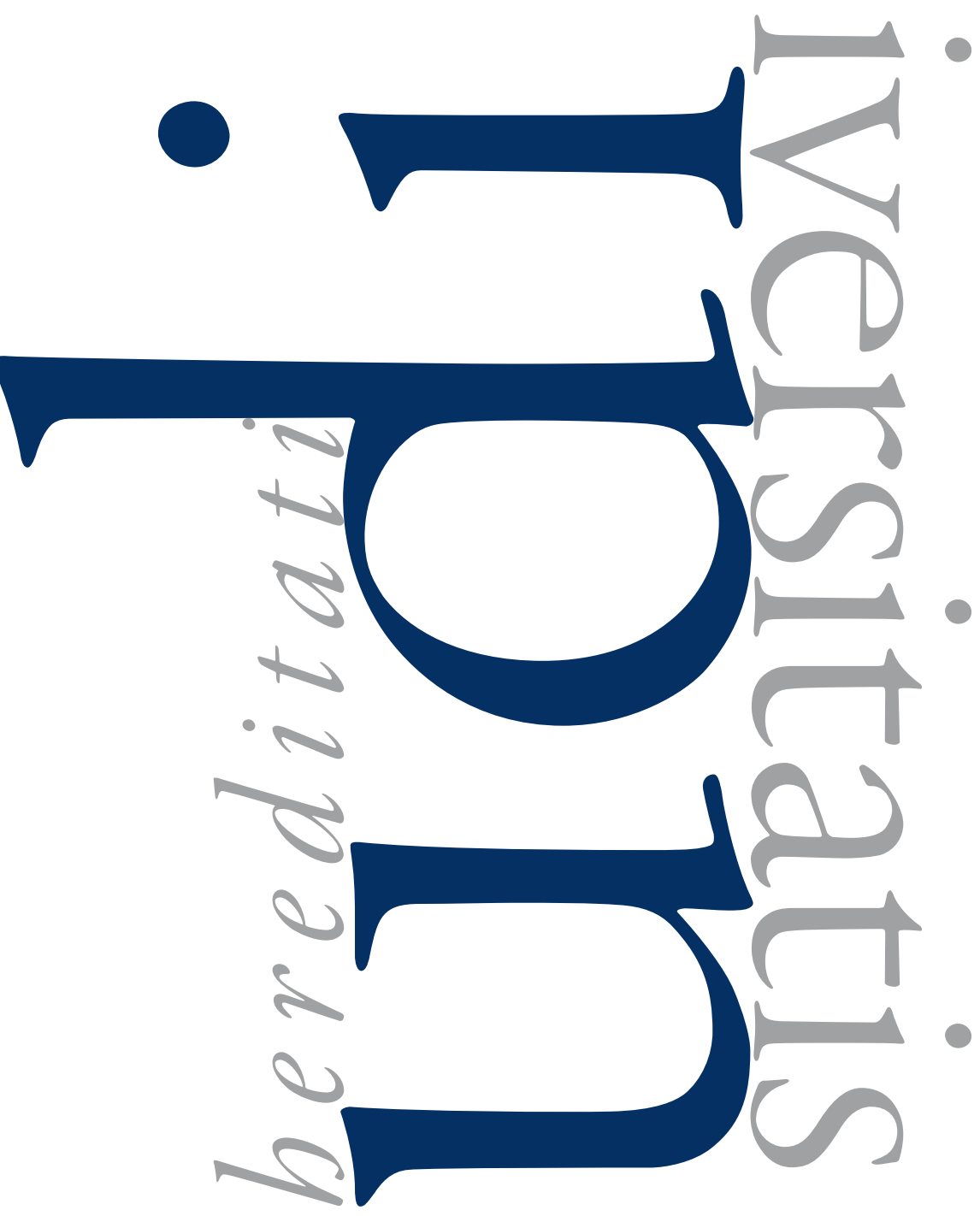

LETNIK 3

ŠTEVILKA 2

LETO 2015
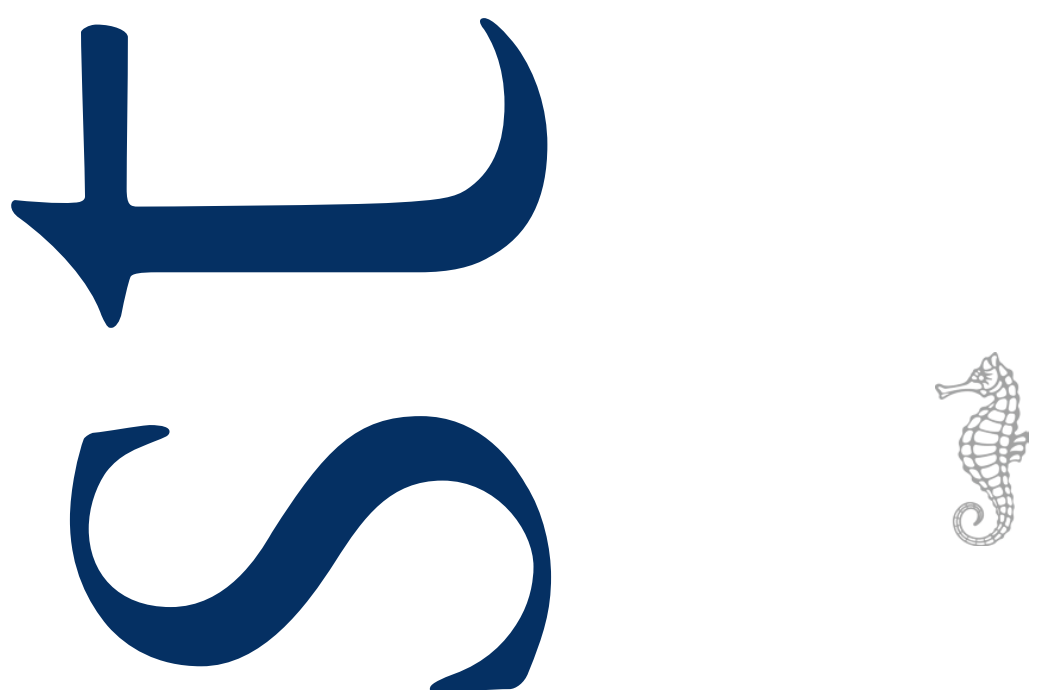
-

r

$\downarrow$

G

1

-

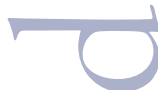

( )

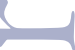

(U)

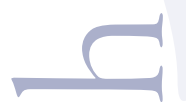




\section{Vsebina/Contents}

Vlasta Begovie and Ivancica Schrunk

9 Le ville marittime nell'adriatico settentrionale (Croazia)

Stefan Groh and Helga Sedlmayer

2 I Ricerche del 2008-2010 nella villa maritima di San Simone/Simonov zaliv presso Isola/Izola (Slovenia)

Neža Gebron Lipovec and Katarina Šmid

27 Cultural Route of Stonemasons and Stones in the Adriatic:

A Conceptual Proposal for the Interpretation and Promotion of Cultural Heritage in Limestone along the Adriatic coast

Jan Cotic

39 Rimski vojaki na območju Slovenije od ustanovitve Akvileje do vdora Markomanov in Kvadov Nils Wiberg

63 How to address Hyperobjects in exhibitions using emerging technologies

Vladimir Kusik

69 Onomastical analysis of inscriptions from Koper and its vicinty

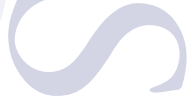


-

r

$\downarrow$

G

1

-

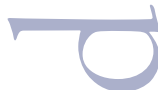

( )

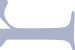

(U)

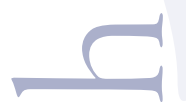




\title{
Le ville marittime nell'adriatico settentrionale (Croazia)
}

\author{
Vlasta Begovič and Ivančica Schrunk
}

This paper is a treatise on maritime villas, an architectural phenomenon specific to Roman coastal settlement - in this case villas ranging from the gulf of Trieste in the southernmost ones on the island of Pag. Our studies on the topography, architecture and development of these villas in Istria suggest the existence of different stages of construction. In Istria the seaside villas were built by the elites which commanded political and economical power. Some of these villas retained their important economic and strategic function until the late antiquity.

Key words: Eastern Adriatic coast, villae maritimae, $2^{\text {nd }}$ century BC to $6^{\text {th }}$ century AD

I: nostri studi sulla topografia e l'architettura delle ville marittime nell'Adriatico settentrionale portano ad un'analisi comparativa con il territorio italiano ed in particolare con il modello di Lafon per lo sviluppo in Italia. ${ }^{\mathrm{x}} \mathrm{La}$ lista delle ville romane tratta dal compendio di località sulla costa orientale dell'Adriatico (Ville romane I) mostra un'area densamente popolata e un paesaggio completamente esplotato. Sono molto numerose pure le ville romane investigate e ubicate, eppure in Istria sono soltanto ir le ville marittime investigate archeologicamente. Le ville marittime rappresentano il tipo più lussuoso di ville romane, costruite su grandi poderi vicino al mare ed estese lungo baie riparate oppure su promontori rocciosi. Sulla costa tirrenica italiana le ville costiere monumentali sono sorte nel I secolo a.C., ${ }^{2}$ mentre la configurazione della costa adriatica orientale e la sua posizione geograficamente vantaggiosa, oltre alle circostanze economiche e socio-politiche vigenti durante il boom edilizio dei secoli I e II, hanno favorito anche qui l'edificazione di tali indubbie imprese architetto-

Xavier Lafon, Villa Maritima (Paris: Boccard, 2001).

Lafon, Villa Maritima, 4 .

DOI: HTTPS://DOI.ORG/10.26493/2350-5443.3(2)9-20 niche dal taglio particolare ed esclusivo. Gli studiosi hanno finora identificato I2 ville marittime nell'Istria romana, cinque ville nei pressi di Pola, due vicino a Parenzo e due nell'ager di Aegida. Il nome villa maritima è stato usato dallo scrittore romano Cornelio Nepote (Vita Attici I 4, 3), mentre Plinio il Giovane e Marziale riportano il $\gg$ mormorio del mare $\ll$ e la $\gg$ vista sul mare $<$ nelle loro descrizioni di queste strutture. La villa marittima è una villa dentro le cui stanze è udibile il suono delle onde: Cicerone vi fece mille passi esercitandosi nei suoi discorsi al suono delle onde. ${ }^{3}$ Queste ville erano ampi complessi architettonici, edificati sulla costa, che approfittavano di tutte le caratteristiche favorevoli del paesaggio e vi si incastravano armoniosamente. Solitamente sono costruite in posizioni di spicco, ad esempio su una penisola o in un' insenatura idonea. Spesso si estendono lungo l'intera costa arrivando talvolta fino al mare, in posizione prospiciente alla proprietà, come riporta una protesta di Orazio, che in un impeto di furia scrive così: »Si sono presi persino il mare, estromettendo il vicino povero dal suo focolare $\ll$ (Ode XVIII). Le

Lafon, Villa Maritima, 3 . 
facciate che danno sul mare sono monumentali, con $\gg$ portici a svolazzo $\ll$, ben noti dagli affreschi in quarto stile pompeiano. Il tratto caratteristico della villa marittima è proprio questo contatto diretto con il mare, oltre alle facciate di sfarzosa rappresentanza, con forme immaginifiche che seguono la configurazione del terreno e consentono piacevoli viste sul mare e sui dintorni. Le innovazioni nei progetti architettonici e le migliorate proprietà tecnologiche del calcestruzzo romano (opus caementitium) nella prima età imperiale permisero di costruire strutture $\gg$ sospese « sul mare, resistenti all'urto delle onde. La villa maritima è una categoria particolare di villa romana, la più esclusiva. Alcune presentano un'architettura dall'impostazione scenografica, dando l'impressione di un palazzo che emerge dal mare. Erano progettate in tal modo allo scopo di impressionare il visitatore, specialmente quando questi entrava nel porticciolo della villa arrivando dal mare.

Gli architetti si impegnavano perciò ad ottenere particolari effetti di spazio. Potendo contare su innovazioni di tale portata, i ceti abbienti cercavano di impressionare i loro contemporanei: queste ville erano uno dei modi in cui i romani benestanti si prodigavano di dimostrare il loro status sociale. ${ }^{4}$ La migliore descrizione della varietà di spazi, servizi e viste che offriva una villa marittima ce la fornisce Plinio il Giovane (Caio Plinio Cecilio Secondo, 6I/62 - I13) nella descrizione letteraria della sua proprietà costiera, Laurentino, a sud di Ostia (Epist., II, I7). Lo spazio interno di questo tipo di villa era rappresentato dal mare: un' insenatura riparata ed arginata in modo da impedire l'accesso alle onde più alte, così che i portici potessero occupare la costa fin quasi al limite estremo della linea di terra, col mare che ogni tanto lambiva le mura dei portici e la presenza di stanze adibite a bagni di sole.

La struttura architettonica di una villa marittima apre quindi verso il bagnasciuga e la vegetazione del giardino di proprietà, avvantaggiandosi appieno del paesaggio e della massima esposizione al sole, incorporando numerosi spa-

4 David Soren and William Aylward, »Dazzling Spaces, « Archaeo$\log y$ 47, no. 4 (1994): 24 . zi aperti (parchi e giardini) e colonnati, in un'architettura ariosa tipica del periodo della $\gg$ pax romana $\ll$ (27 a.C. -167 d.C.). Gli elementi tipici di queste strutture comprendono degli isolati residenziali di elevato standard abitativo con peristili e giardini interni ( $x y s t i)$ paesaggisticamente organizzati che si estendono all'esterno verso parchi con padiglioni destinati a convivi, terme e divertimenti, e strutture monumentali quali $p a-$ laestrae, diaetae, are e ninfei. ${ }^{5}$ L'esempio finora più significativo ad essere stato esaminato è Villa Pausilypon nella baia di Napoli, i cui giardini comprendono strutture quali un teatro e un odeon. $^{6}$

\section{Villae marittimae nell'Adriatico settentrionale}

Lo sviluppo delle ville marittime sulla costa adriatica orientale è collegato alla fondazione di colonie romane e alla relativa urbanizzazione, all'agricoltura intensiva ivi praticata e alla loro ubicazione sulle rotte di navigazione più trafficate dell'Adriatico. La colonizzazione romana introdusse una cultura nuova, dando luogo a cambiamenti profondi nell'assetto della popolazione autoctona e nella struttura insediativa. Le colonie incisero direttamente sullo sviluppo di proprietà rurali e la conseguente costruzione di ville; i mutamenti più rilevanti si ebbero proprio nella stretta fascia costiera.

Allo stato dell'arte delle ricerche condotte sulle ville romane della costa adriatica orientale, gli archeologi hanno rilevato i resti di is ville marittime sul territorio di Italia, Slovenia e Croazia. Di queste a tutt'oggi poche sono state esaminate; tra queste ultime, alcune presentano tratti monumentali. Dato che la maggioranza di queste ville attende di esser sottoposta a esame appropriato, il nostro sapere sulla loro tipologia è scarso. Il commercio di vino ed olio d'oliva istriani, prodotti presso vaste proprietà, rappresentava il collegamento economico più precoce

Maddalena Cimma and Eugenio La Rocca, La tranquille dimore degli Dei: La residenza imperiale degli Horti Lamiani (Venice: Marsilio, 1986), 19

6 Lafon, Villa Maritima, 406-10. 
con la regione d'Aquileia. Tale produzione infuse una spinta all'attività edilizia nei centri urbani di nuova fondazione e nelle aree rurali circostanti. La costruzione delle prime ville costiere in Istria si svolse sotto l'egida della colonizzazione cesarea, la quale ebbe un effetto propulsivo per lo sviluppo economico: la cosiddetta »villa catoniana $\ll$, comprendente settori in funzione rispettivamente agricola e residenziale, fu la risposta più idonea alle nuove circostanze economiche e sociali. Lo sviluppo economico in epoca augustea ebbe come risultato una sovrapproduzione che si tradusse in maggior ricchezza, gettando le basi per la costruzione di ville marittime dalla planimetria ispirata a quelle della costa tirrenica. Tra gli anni 18 e I2 a.C., Augusto annesse l'Istria nella Decima Regio chiamandola Venetia et Histria ed i terreni istriani, ora in territorio italiano, furono dichiarati esentasse. Il proliferare di ritrovamenti di anfore istriane di tipo Dressel 6B indica chiaramente l'intensificarsi dell'olivicoltura e della produzione olearia in tarda età augustea. Il mutato status amministrativo della regione e la sua ripresa economica in questo periodo non sono dovuti a coincidenza; fu piuttosto lo stesso Augusto a nutrire interesse personale per l'economia istriana, tesi avvalorata dalle argomentazioni di A. Starac sull'ubicazione dei poderi imperiali in terra istriana, tanto che è probabile che fosse l'imperatore stesso a concedere terreni e prestiti a ricompensa della lealtà e dei servigi resi dai beneficiari. ${ }^{7}$ Gli investimenti senatoriali in colture da reddito istriane e l'accesso ai nuovi mercati, civili e militari, di Norico e Pannonia dipendevano dalle politiche imperiali, le quali, secondo F. Tassaux, ${ }^{8}$ favorivano il Nord Italia e, appunto, l'Istria. E' altresì probabile che ci sia stato un programma economico di più larga scala, dato che J. D'Arms attribuisce ad Augusto l'applicazione di politiche simili in Campania. ${ }^{9}$ Le politiche imperiali e gli inte-

Alka Starac, »Carski posjedi u Histriji, « Opuscula Archeologica I8 (1995): 139-40.

8 Francis Tassaux, »Laecanii, recerches sur une famille senatoriale d Istrie, « Mélanges de l'Ecole française de Rome: Antiquité 94 (1982): 265. John D'Arms, Romans on the Bay of Naples (Cambidge: Harvard University Press, 1970), 82 ressi economici della classe dirigente concorsero di pari passo allo sviluppo delle ville marittime in Istria, dove pochi membri della ristretta cerchia imperiale arrivarono a creare delle economie di scala.

Queste le ville marittime che troviamo oggi in Italia e Slovenia: Barcola presso Trieste (Italia), Baia di San Simone (Slovenia), Fornace presso Pirano (Slovenia).

Queste le ville marittime che troviamo oggi in Croatia -

I. La prima villa marittima da noi presa in esame è quella nel territorio della colonia romana di Tergeste (l'odierna Trieste), datata al I secolo d.C. Il sito, scavato solo parzialmente, si trova tuttavia su un promontorio basso, chiamato oggi Catoro (da Ca' d'oro = domus aurea), che si estende penetrando dentro due insenature da ambo i lati. Si tratta di una posizione alquanto panoramica, con viste mare da tutti i lati. In cima al promontorio sono stati ritrovati i resti architettonici di alcuni vani sfarzosi - un peristilio, una fila di stanze, delle ampie terrazze e mura in tecnica opus isodomum. Le terme si trovavano a nord, nella baia di S. Margherita (sito Tiola), mentre un'ampia piscina semicircolare a compartimenti dava sulla baia sud. ${ }^{\circ}$ Ritrovamenti di decorazione architettonica quali argini in marmo e mosaici ed affreschi policromi indicano opulenza costruttiva e suggeriscono che la villa fu costruita con funzione di otium. Le aree esaminate non presentano prove di attività agricola. Scavi recenti hanno portato alla luce una necropoli tardoromana adiacente al complesso termale. Una delle tombe, a due inumazioni e d'architettura monumentale, conteneva recipienti in ceramica e vetro d'importazione, un bracciale in argento, un amo da pesca e una moneta in bronzo con l'effigie di Diocleziano. ${ }^{\text {II }}$ Risulta chiaro che le terme smisero di avere questa funzione nella tarda antichità e furono conseguentemente o abbandonate, o trasformate in cappella cristia-

\footnotetext{
Io Smiljan Gluščević and Narcisa Bolšec Ferri, »Izvješće o podmorskim arheološkim radovima u Katoru kod Umaga, « Obavijesti Hrvatskog arbeološkog drustva I (2003), I I6.

I I Narcisa Bolšec Ferri, Zaśtitno revizijsko arheološko istraživanje Sepomaja 2003 (Umag: Muzej grada Umaga, 2003).
} 
na con annesso cimitero: sviluppi simili non erano affatto strani nelle ville di lusso in Istria e altrove nel Tardo Impero. La tomba era lastricata di tegole bollate datate al I secolo, altro segno di mutamenti sostanziali nella villa e di furto di materiale edile. Tre tegole recano il bollo di P. Clodio Quirinale, prefetto della flotta di Ravenna ai tempi di Nerone e proprietario terriero senatoriale in territorio triestino, nonché con ogni
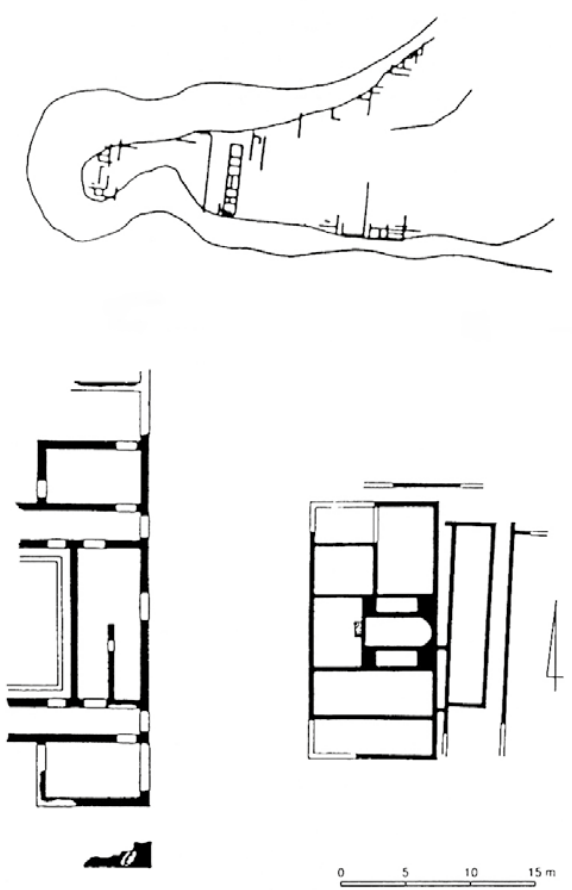

I. La villa marittima a Catoro - il foto e la pianta (Matijašić 1998)

2. Secondo, a nord di Parenzo, nella località di Loron, si trova una vasta proprietà che si estende tra due baie, Santa Marina e Porto Cervera, lungo il promontorio che le separa. Questa era la sede del secondo opificio di anfore per grandezza in Istria, attivo dal I al IV secolo, posizionato sul lato nord della baia di Porto Cervera. Agli inizi del I secolo, l'officina produceva anche terra sigillata e tegole. Recenti scavi franco-italo-croati hanno riportato alla luce le strutture produtti-

I2 Federica Fontana, La villa romana di Barcola: A proposito delle villae maritimae della regio $X$ (Roma: Quasar, 1993). probabilità della villa marittima a Barcola presso Trieste, dove sono state ritrovate numerose tegole bollate riportanti il suo nome. ${ }^{\mathrm{I} 2} \mathrm{E}$ ' altresì possibile che sia di sua proprietà e costruzione anche la villa a Catoro. Le foto aeree della villa marittima a Catoro presso Umago rendono visibili le strutture oggi sommerse che potrebbero rappresentare i vari impianti della villa, a tutt'oggi inesplorati.

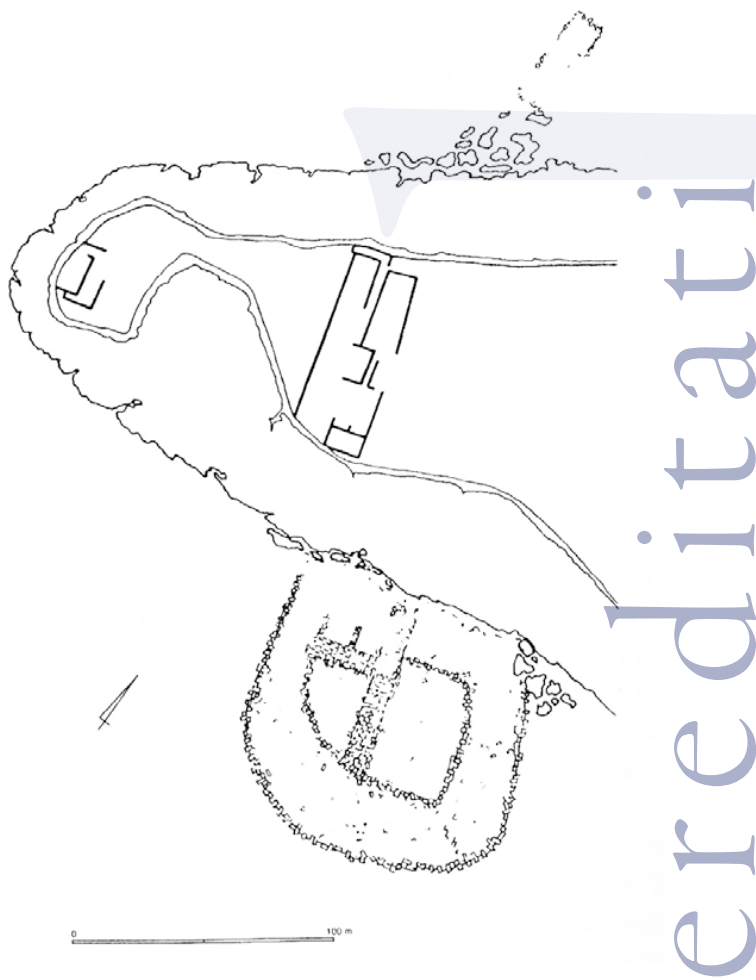

ve, incluse fornaci da vasellame. ${ }^{\mathrm{I} 3}$ Fornaci ed edifici con torchi per l'olio erano stati ritrovati negli anni ' 70 del secolo scorso sul lato sud della baia. ${ }^{14}$ I bolli ritrovati su sigillata, anfore e tegole indicano come proprietari i senatori Cornelio Sisenna, Statilio Tauro e Calvia Crispinilla. Durante Domiziano, questo opificio e quello di proprietà dei Laecanii a Fasana divennero proprietà impe-

I3 Francis Tassaux, Robert Matijašić, and Vladimir Kovačić. Loron (Croatie) (Bordeaux: Ausonius, 2001), 89,312

I4 Vesna Jurkić Girardi, »Scavi in una parte della villa rustica romana a Cervera porto presso Parenzo, «Atti Centro recherché Storiche di Rovigno (1979). 
riali, mentre non ci è dato sapere del destino degli altri poderi di queste famiglie. E' possibile che le loro ville marittime fossero state parimenti dichiarate proprietà imperiale.

Nei pressi di questo sito produttivo una villa marittima è stata localizzata, anche se non esaminata. Lungo la costa curvilinea nei pressi della baia di Santa Marina e sulle pendici del relativo promontorio vi sono tracce di edifici sparsi eretti sia a livello del mare che su terrazze, secondo quanto confermato da un' indagine geofisica. L'équipe franco-italo-croata ha qui avuto occa- sione di studiare un'ampia piscina vivaria, situata nella baia menzionata, di cui due frammenti di mosaico bianco e nero, palesemente appartenenti a una superficie più vasta e rinvenuti a Loron, sono ora esposti al Museo di Parenzo. Il bordo che incornicia il mosaico penetrandone il campo, una bianca foglia d'edera su sfondo scuro situato a margine della composizione, nonché una guilloche bifascia bianca su sfondo scuro sono motivi tipici dei mosaici dell'epoca flavia, alla fine del I secolo. ${ }^{\text {Is }}$

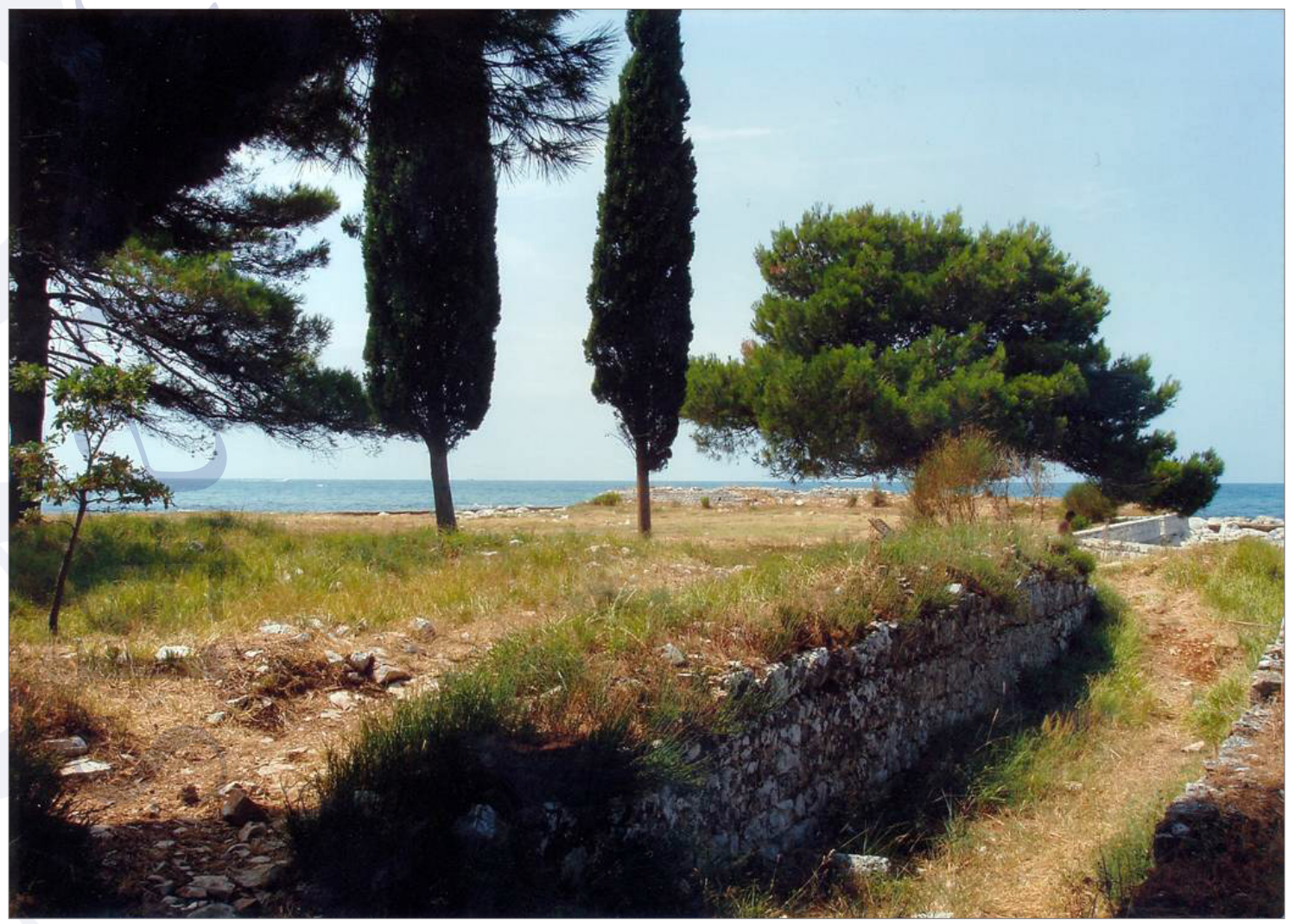

2. La villa marittima a Loron - la pianta da un parte di villa (Kovačić, Marchiori, Marion, Rosada, Rousse, Tassaux 20ıo)

3. A sud della città Parenzo, sullo stretto promontorio di Sorna oggi inglobato dal villaggio turistico Laguna Verde, negli anni ‘6o del secolo scorso è stata rinvenuta un'ampia villa (I5O $\mathrm{x} 130 \mathrm{~m}$ ). La villa è posta sopra il promontorio

I5 Jagoda Meder,Podnimozaici u Hrvatskoj(Zagreb: Ministarstvo kulture Republike Hrvatske, Uprava za zaštitu kulturne baštine, 2003), 29. e i suoi lunghi portici danno, con ampie vedute, su tutti tre i lati. La simmetria assiale delle due strutture a peristilio indica un progetto edilizio univoco e non bifase. ${ }^{16}$ Un ampio triclinium era posto al centro, nel punto più alto del promonto-

I6 Robert Matijašić, Gospodarstvo antičke Istre (Pula: »Žakan Juri«, I998), I26. 
rio; la luce penetrava dai peristili laterali. Le stanze erano ornate con mosaici policromi e pitture murali, datati al I e II secolo. L'edificio termale si trovava nella baia est, vicino al mare; secondo l'artefice degli scavi, la struttura nell'angolo basso sinistro fu aggiunta nel IV secolo. Le aree interessate dagli scavi non presentavano tracce di attività agricole in situ o nei pressi: è probabile che ci troviamo di fronte a una villa imperiale adibita ad otium. Nella seconda fase, al centro dell'edificio fu eretta una piccola struttura rettangolare con delle aggiunte laterali: probabilmente si trattava di una chiesa.

4. Proseguendo lungo la costa, a Barbariga, a nord della figulina di Fasana, gli archeologi hanno localizzato il più grande oleificio istriano del primo impero. Dei quattro siti di produzione ubicati entro un'area di $2 \mathrm{~km}^{2}$ l'uno dall'altro, uno constava di 5 torchi e un altro di addirittura 20. Quest'ultimo sito, ubicato nella baia di Porto delle Colonne presso Barbariga, conteneva i resti di una fullonica mentre a Punta Cissana (o Punta Barbariga) furono rinvenute conchiglie murex sminuzzate tardoantiche. L'edificio residenziale era un'ampia villa marittima che si estendeva sul promontorio. ${ }^{17}$ La planimetria della villa mostra tre edifici collegati terminanti in un molo e relativo porticciolo. La parte più antica della villa è l'ala nord. Il primo edificio è probabilmente l'originaria villa planimetrica con portico frontale, paragonabile al Tipo B lafoniano, a cui vennero aggiunti edifici di rappresentanza adornati da mosaici. La maggior parte dei mosaici era bianca con due bordi neri a cornice, mentre gli altri erano neri con uno o due bordi bianchi. Il peristilio si apriva a una vista panoramica del bagnasciuga ed entrambe le facciate erano adornate da gradinate monumentali. La progressione di stanze situate sui tre lati del peristilio conteneva mosaici bianchi e neri con motivi geometrici e altri mosaici policromi. Tra i resti v'erano due frammenti di affreschi di terzo stile pompeiano. ${ }^{18}$ Anche le terme appartengono alla fase posteriore. Gli scavi nel sito si sono svolti all'inizio del XX se-

I7 Hans Schwalb, Römische villa bei Pola (Wien: Hölder, 1902).

I8 Meder, Podni mozaici u Hrvatskoj, 44 colo e sussiste pertanto la necessità di una nuova campagna al fine di chiarire le varie fasi costruttive. La densità e la quantità di ville marittime nell'Istria meridionale, specie nei pressi dell'antico capoluogo regionale di Pola, sono indicativi dell'importanza economica e politica del ceto dirigente.

A nord di Pola vi sono due grandi siti, uno sull' isola di Brioni Maggiore e l'altro dirimpetto sulla costa, a Valbandon. Al vertice di questo triangolo, a Fasana, si trovava il più grande opificio di anfore istriano, di proprietà della famiglia senatoriale dei Laecanii.

5. La villa marittima nella baia di Val Catena sull' isola di Brioni Maggiore è la più complessa ritrovata finora sulla costa adriatica orientale. La villa, come pure tutta l'isola, era probabilmente di proprietà della famiglia dei Laecanii. ${ }^{19}$ E' questo l'unico sito in cui le fasi edilizie, da tardorepubblicana a primo imperiale, sono palesi. La pittoresca baia di Val Catena vide così riattare un'originaria villa catoniana, con tanto di pars rustica e pars urbana, in una maritima terrazzata, con una domus nuova e porticati monumentali a lambire il mare. La villa originaria era una combinazione tra Tipo A con cortile centrale e Tipo B lafoniani, ${ }^{20}$ una villa planimetrica con portico frontale. Gradualmente, nel corso del I secolo, l'intera baia fu edificata a contenere servizi monumentali per un'estensione di oltre 6 ettari. $^{21}$ La villa comprendeva un ampio raggio di lunghi colonnati che davano sul mare e un cortile a peristilio che fungeva da punto focale raggruppante i vari edifici, di funzione varia - residenziale e religiosa (templi di Nettuno e Venere, un ninfeo), oltre a una biblioteca, una palaestra e le terme - tutti collegati da colonnati e pergolati. Il complesso termale presentava un colonna-

19 Tassaux, Laecanii, 246; Tamas Bezeczky, The Laecanius amphora stamps and the villas of Brijuni (Wien: Verlag der Österreichischen Akademie der Wissenschaften, 1998); Ivančica Schrunk and Vlasta Begović, »Roman estates on the island of Brioni, Istria, «Journal of Roman Archaeology 13 (2000).

20 Lafon, Villa Maritima, 30.

2I Anton Gnirs, »Überreste römischen Ansiedlungen in der Gegend zwischen Pola und Rovigno, «itteilungen der K. u K. Zentralkommission zur Erforshung und Erhaltung der Baudenkmäle 27 (1901); Anton Gnirs, »Forschungen über antiken Villenbau in Südistrien, « Jahreshefte des Österreichischen Archäologischen Instituts I8 (I915). 
to semicircolare che percorreva la linea costiera e una banchina in pietra. Non lontano c'era una piscina vivaria rettangolare. ${ }^{22}$ The villa comprendeva tre tipi di paesaggio: la baia naturalmente riparata, le pendici di tre colli e gli ameni prati circostanti. Loriginaria pars rustica era rimasta in funzione, mentre i vari servizi furono costruiti lungo la baia. Contrariamente alle osservazioni di Lafon sulla maggioranza delle ville marittime primo imperiali di Lazio e Campania, non abbiamo rilevato trasferimenti della produzione in seguito alle aggiunte monumentali: agricoltura decorativa e pescicoltura rimasero parte integrante di questo buen retiro ad alto rendimento.

6. La villa nella baia profonda di Valbandon era stata parzialmente oggetto di scavi all' $i$ nizio del Novecento; ne urgono di nuovi al fine di chiarirne la cronologia e il rapporto tra le due parti sul lato opposto della baia. ${ }^{23}$ Forme architettoniche immaginifiche e il rinvenimento di decorazioni pregiate quali una pavimentazione in opus scutulatum indicano che si trattasse di una residenza di lusso. Quasi tutte le aree residenziali nel complesso sud presentano decorazioni a mosaico. Due esedre nella parte settentrionale della baia erano decorate di mosaico nero con crustae; dietro ad esse vi è l'ala nord del settore residenziale, che presenta tracce di mosaici e pavimenti in opus sectile. Si conferma la produzione di olio d'oliva nell'area grazie a rinvenimenti di alcuni frammenti di torchio, ma non il collegamento di questa produzione con la villa stessa. C'erano prove che l'area interna della baia era chiusa a formare una piscina, approvvigionata da un torrente che vi terminava. Il complesso è datato al I secolo, con restauri dei mosaici a più riprese in tarda antichità. ${ }^{24}$ I resti della fullonica appartenente al podere si estendono fino a Punta Cristo. Un'ulteriore valutazione della funzione, produttiva o di diporto, di questa villa sarà possibile solo in seguito a nuovi scavi.

22 Vlasta Begović Dvoržak, »Antička vila u uvali Verige na Brijunima, «Vijesnik arheološkog muzeja 23 (1990): 98.

23 Matijašić, Gospodarstvo anticke Istre, 122.

24 Monika Verzar Bass, »Le transformazioni agrarie tra Adriatico nordorientale e Norico, «in Società Romana e impero tardoantico, ed. Andrea Giardina (Roma: Editori Laterza, 1986), 656.
7. L'area a sud di Pola è caratterizzata da vasti promontori e insenature profonde. Le risorse naturali comprendono qui strati di pietra laterizia di alta qualità, campi fertili e baie riparate; tra Bagnole and Promontore troviamo inoltre zone con pietra calcarea di alta qualità. Cinque siti presentano prove di produzione d'olio d'oliva, tra cui la villa marittima parzialmente esplorata e situata nell'interno della baia di Bagnole, dalle fasi di costruzione tuttora sconosciute. La planimetria rileva una villa con corridoio centrale a separare due file di stanze. ${ }^{25}$ Il porticato che percorreva tutta la facciata frontale con tanto di vista panoramica sul mare caratterizza la villa come marittima e simile a quelle rappresentate nei murali in quarto stile pompeiano.

8. Ad est di Bagnole, nei pressi dell'odierna Medolino, la più grande villa marittima nell'area, e probabilmente in Istria, occupava il grosso del promontorio di Visola. Il promontorio si situa dentro una baia profonda che offre approdo sicuro e riparo da tutti i venti. L'attraversamento al largo tra la punta meridionale dell'Istria e l'isola di Unì in condizioni di bora è molto pericoloso: le imbarcazioni che percorrevano l'Adriatico in entrambe le direzioni dovevano attendere che il vento cessasse per proseguire e le flotte riparavano spesso in baie come questa, persino durante l'inverno. La villa poteva contare su una posizione panoramica e di conseguenza di un'ottima sorveglianza degli stretti sfocianti nella baia. ${ }^{26} \mathrm{Dal} 1995$ vengono monitorati i resti della villa sul promontorio e sulle strutture sommerse. Scavi eseguiti a più riprese hanno riesumato varie piccole aree e le mura percorrono la costa per qualche chilometro; alcune mura sono ora sommerse e vari edifici sono disposti ad angolazioni diverse. L'intera villa, costruita su tre terrazze, copriva circa io ettari. ${ }^{27}$ Per dimensioni e disposizione a strutture sparse è paragonabile alla villa imperiale di Pausilypon vicino a $\mathrm{Na}$ -

\footnotetext{
25 Matijašić, Gospodarstvo antičke Istre, I35.

26 Vesna Jurkić Girardi, »Archaeological researches of the marittime roman/late roman villa on the Vižula peninsula (Isola del vescovo) near Medulin in 2006 and 2007, « Histria Antiqua I5 (2007): 475.

27 Kristina Džin, »Spomenički nalazi i projekt ekoparka Vižula kod Medulina, Histria Antiqua I (1995).
} 
poli, la quale si estende per oltre 9 ettari. ${ }^{28}$ Sono state rinvenute parti di porticato lungo e logge con pavimentazione a mosaico come in figura, nel punto di collegamento tra terrazze e gradinata monumentale. I rinvenimenti di mosaici, statue e marmi sono indice di notevole lusso. I reperti minuti datano la struttura dal I al VI secolo. ${ }^{29}$ Alcuni degli edifici esaminati presentano tracce di muri divisori in tarda antichità, forse per accogliere un numero accresciuto di persone, probabilmente soldati.

Le altre villae marittime, ma quelle dove scavi archeologici non sono finiti e risultati non sono ben documentati e proprio pubblicati sono: 9. Havišće presso Jadranovo (scavi archeologichi guida Ranko Starac); ıo. Selce presso Crikvenica. Una villa marittima dove è oggi costruito albergo »Slaven «, può essere associato con il proprietaria da figlina romana a Crikvenica (Ad Turres) Sextus Metilius Maximus; ${ }^{3 \circ}$ II. Njivice a isola di Krk ( una villa marittima che si trova vicino da città romana Fulfinum, c'era trovato un edificio circolare di is metri di diametro; ${ }^{31} \mathbf{I} 2$. Šimuni a isola di Pag. Può essere associato con la famiglia di Calpurnius Piso che è noto per aver avuto le loro proprietà sull'isola di Pag. È stato trovato un l'iscrizione $\gg$ Calpurnia L. Pisonis Auguris Filia $\ll^{32}$

\section{Conclusioni}

Quando nel 2003 è stata pubblicata una tipologia di ville romane in territorio croato redatta secondo la tipologia di Torrenato (200I), si è potuto desumere che la penisola istriana ospiti alcuni dei tipi più antichi di villa romana, specie nel primo strato di ville più tardi ampliate (alcune di queste, appunto, in funzione di ville marittime).

28 Lafon, Villa Maritima, 406-07, fig. 136.

29 Vesna Jurkić Girardi, »Le antique hearths in the roman residential villa on the Vižula peninsula near Medulin, «istria Antiqua 16 (2008): 162

30 Goranka Lipovac Vrkljan, »Keramičarska radionica u Crikvenici Ceramics Workshop in Crikvenica, « in International Archaeological Symposium: Sumaries of Reports (Pula, 2006).

3I Mihovil Bolonić and Ivan Żic, Otok Krk kroz vjekove (Zagreb: Kršćanska sadašnjost, 1977).

32 Marin Zaninović, »Villae rusticae u pejsažu otoka i obale antičke Dalmacije, « Histria Antiqua I (1995).
La villa marittima nella baia di Val Catena nell'arcipelago di Brioni constava di una prima fase costruttiva, finora sconosciuta, sotto il colle Moribon. Secondo la tipologia di Torrenato, la serie di vani disposti in corrispondenza del mare e raggruppati intorno al corridoio centrale I, oggi sommersi, potrebbero appunto rappresentare questa prima fase edilizia, a cui era seguita una villa rustica con corte centrale di tipo atrium dipluvium, edificata nella seconda metà del I sec. a.C. Tracce della prima villa si rilevano negli strati inferiori della seconda, come pure nel caso della villa rustica nella baia di Val Madonna.

E' interessante notare che anche la prima edificazione della villa marittima a Barbariga presenta la stessa tipologia più antica di villa romana con corridoio centrale e vani che si affacciavano su entrambi i lati; lo stesso dicasi della villa marittima a Bagnole, a sud di Pola.

Il nostro studio delle ville marittime nella regione adriatica settentrionale era condizionato dallo stato irregolare degli scavi archeologici e relative pubblicazioni per tutto il territorio. L'assetto spaziale delle ville in Istria risulta perlopiù ben documentato, come pure le prove disponibili sulla proprietà di questi complessi. Nell'Istria romana l'élite coloniale, la quale possedeva al contempo vasti appezzamenti terrieri, costruì le ville marittime in seguito allo sviluppo di economie di scala. Le ville avevano funzione molteplice e mista, tuttavia quelle prevalenti erano di produzione di colture da reddito (per i fabbisogni della villa e per il mercato) e di controllo delle vie di mare strategiche. Ciononostante, la funzione fondamentale di ogni villa marittima era il soggiorno stagionale del proprietario e il godimento dell'otium in un'amena casa al mare. Per questo motivo molte ville disponevano di piscinae vivariae prospicienti alla costa (Catoro, Loron, Valbandon, Brioni-Val Catena e baia Ribnjak, Medolino-Visola). Piscinae vivariae di dimensioni ridotte e di disposizione particolare fungevano piuttosto da aquaria per particolari varietà di pesci e altre attrattive e non venivano utilizzate per l'ittiocoltura produttiva a scopo 
alimentare, scopo al quale venivano invece adibite vaste pozze e, in certi casi, recintate intere baie (Valbandon, Brioni-Ribnjak). I più piccoli vivaria, progettati per l'occasione, servivano perlopiù da attrazioni; disponevano di camere separate per poter ospitare differenti varietà di pesci (Catoro, Loron, Brioni). La piscina vivaria della villa a Catoro era costituita da un semicerchio con parete divisoria nel mezzo; quella della villa a Loron constava di tre camere; quella nella baia di Val Catena sull'isola di Brioni aveva varie camere rettangolari di dimensioni diverse e collegate da canali, probabilmente con partizioni che consentivano l'apertura e la chiusura dei canali, di modo da poter controllare il movimento dei pesci.

Molte ville presentavano finiture di lusso, al punto che in alcune di esse troviamo pavimentazione eseguita con la tecnica dell'opus scutulatum - una combinazione di lastre in marmo tagliate in varie forme geometriche e mosaico (Valbandon, Visola presso Medolino). Per la loro ubicazione differenziamo tra ville marittime costruite su penisole e quelle dentro porti. Per tipo di unità architettoniche, differenziamo tra ville di tipo a portico, ville del tipo a peristilio, e ville che sono una combinazione dei due tipi. Le facciate monumentali dominano la costa, mentre negli spazi interni si rileva una giocosa esigenza di lusso personalizzato, che riflette una filosofia di vita epicurea ed un approccio all'arredo spaziale raffinato e, spesso, alquanto anticonvenzionale, tanto che si può dire che ogni villa rappresenta una creazione a sé. Talvolta queste ville dispongono di servizi di lusso quali biblioteche, palaestrae, templi e terme, come nel caso della villa sulle isole Brioni. Le volte, le colonne, i capitelli, gli sfarzosi pavimenti in marmo e mosaico, sono tutti dei $\gg$ must $\ll$ di una villa marittima.

Una villa marittima era di gran valore e per costruirla si incorreva in spese straordinarie: Orazio narra le difficoltà dei loro proprietari, la loro irascibilità ed irritabilità, il sonno leggero appesantito dalle preoccupazioni, raccontando inoltre di ville così grandi da coprire il mare stesso. »Tu erigi il tuo monumento di marmo ed estendi i tuoi palazzi sulle rive delle Baiae« (Lib. II, Car. XVIII). »I proprietari di vasti poderi hanno mille pensieri; i costruttori di grandi ville al mare spesso cercano di sfuggire invano ai loro problemi «. Conclude infine: $\gg \mathrm{Nemmen}$ $\mathrm{l}$ ' indomo mar recar può pace a colui che troppo agogna $\ll$ (Ode XVIII).

Gli autori del volume sulla villa marittima a Loron hanno cercato di determinare la vastità dell'area di proprietà occupata dalla villa, concludendo che è probabile che i poderi marittimi si estendessero per diversi chilometri lungo la costa. ${ }^{33}$ Le numerose ville situate in prossimità di centri urbani (più o meno a un giorno di viaggio), ad es. quelle intorno ad Aegida, Parenzo e Pola, confermano l'ipotesi che i potentati rurali del tempo appartenessero anche all' élite urbana. $^{34}$

Vario il destino delle ville marittime nella tarda antichità. La loro architettura monumentale consentì l'assunzione di nuove funzioni, il livello di sfarzo rimanendo invariato. Strutture produttive quali le fullonicae furono annesse ad alcune ville (es. Barbariga, Val Catena su Brioni, Valbandon, Fornace presso Pirano), mentre altre si videro riattate in insediamenti tardoantichi o in basi militari marittime sulle rotte adriatiche più importanti (Catoro, Castrum-Val Catena, Visola presso Medolino). I resti di vasellame e quegli architettonici suffragano la tesi secondo cui diverse ville marittime - probabilmente quelle divenute in seguito proprietà imperiali - fecero da basi militari e navali e da sedi di comandanti militari della tarda antichità (come documentato su Brioni). Molto rimane ancora da fare per esplorare i siti finora individuati e spiegare esaurientemente il destino di queste straordinarie opere architettoniche.

\section{Summary}

The article outlines a picture of the seafront villas on the coastline extending from the northernmost Gulf of Salvore to the island of Pag in the south. The sea vil-

\footnotetext{
33 Tassaux, Matijašić, Kovačić, Loron, 355.

34 C. R. Whittaker, »The consumer city revisited: The vicus and the city, «ournal of Roman Archaeology 3 (I990): I I I.
} 
las in the northern Adriatic are by far the best explored among the Roman villas of east Adriatic coast; many feature a partially defined planimetry.

Maritime villas represent a specifically Roman architectural phenomenon of coastal settlement. Some of them were large and magnificent architectural structures built by the Roman elites to demonstrate their economic and political power. Our studies on the topography, architecture and development of these villas in Roman Istria suggest the existence of different stages of construction. In Istria, the seaside villas were built by senatorial and colonial elites, which had developed economies of scale in the agricultural and natural resources sectors, gaining important offices in Rome. Their names are documented on amphorae and square tiles. In the late antiquity, the economic and strategic function of villas, particularly those on the most important navigation routes, was crucial for the Adriatic region.

\section{Povzetek}

Članek se posveča podobi obmorskih vil, posejanih vzdolž jadranske obali od zaliva Salvore na severu do otoka Pag na jugu. Obmorske vile (la. villa maritima) na severnem Jadranu so daleč najbolje raziskane med rimskimi vilami na vzhodni jadranski obali; mnoge imajo delno definirano planimetrijo.

Pomorske vile predstavljajo prav poseben rimski arhitekturni fenomen obalne poselitve. Nekatere od njih so bile velike in veličastne arhitekturne strukture, ki so jih zgradile rimske elite, da bi izkazale svojo gospodarsko in politično moč. Naše študije o topografiji, arhitekturi in razvoju teh vil v rimski Istri kažejo na obstoj različnih stopenj gradnje. V Istri so obmorske vile zgradile senatorske in kolonialne elite, ki so razvile obsežno gospodarsko dejavnost v kmetijskem sektorju in izkoriščanju naravnih virov, se potegovale za pomembne položaje v Rimu itn. Njihova imena so dokumentirana na amforah in na opeki. V pozni antiki je bila ekonomska in strateška funkcija vil, zlasti tistih na najpomembnejših navigacijskih poteh, bistvenega pomena za jadransko regijo.

\section{Bibliography}

Begović Dvoržak, Vlasta. »Antička vila u uvali Verige na Brijunima.«Vijesnik arheološkog muzeja 23 (1990): 97-IIO.
Begović, Vlasta, and Ivančica Schrunk. $\gg$ Rimske vile Istre i Dalmacije: I dio: Pregled lokaliteta.«Prilozi Instituta za arheologiju 19 (2002): 113-30.

Begović, Vlasta, and Ivančica Schrunk. »Roman Villas in Istria and Dalmatia, Part III: Maritime villas.« Prilozi Instituta $z a$ arheologiju 2I (2004): 65-90.

Begović, Vlasta, and Ivančica Schrunk. The Brijuni Islands: Past Architecture and Cultural Heritage. Zagreb: Tehnička knjiga, 2007.

Begović, Vlasta, and Ivančica Schrunk. »Rising of the Sea Level on the Eastern Adriatic Coast.« In Remote Sensing Techniques in Disaster Management and Emergency Response in the Mediterranean Region, EAR$\mathrm{SeL}$, edited by Marinko Oluić and Ivan Gušić, 289-300. Zagreb: EARSeL, 2008.

Begović, Vlasta, and Ivančica Schrunk. »Maritime Villas on the Eastern Adriatic Coast (Roman Histria and Dalmatia).« In Roman Empire and Beyond: Archaeological and Historical Research on the Romans and Native Cultures in Central Europe, edited by Eric C. De Sena and Halina Dobrzanska, 3-2I Oxford: BAR, 201 .

Bezeczky, Tamas. The Laecanius Amphora Stamps and the Villas of Brijuni. Wien: Verlag der Österreichischen Akademie der Wissenschaften, 1998.

Bolšec Ferri, Narcisa. Zaštitno revizijsko arheološko istraživanje Sepomaja 2003. Umag: Muzej grada Umaga, 2003.

Boëthius, Axel, and John Bryan Ward Perkins. Etruscan and Roman Architecture. London: Penguin, 1970.

Cimma, Maddalena, and Eugenio La Rocca. La tranquille dimore degli Dei: La residenza imperiale degli Horti Lamiani. Venice: Marsilio, 1986.

Bolonić, Mihovil, and Ivan Žic. Otok Krk kroz vjekove. Zagreb: Kršćanska sadašnjost, 1977.

Crema, Luigi. Storia dell' architettura romana. Torino: Società Editrice Internazionale, 1959 . 
D'Arms, John. Romans on the Bay of Naples. Cambidge: Harvard University Press, 1970.

Džin, Kristina. »Spomenički nalazi i projekt ekoparka Vižula kod Medulina.« Histria Antiqua I (1995): 73-8.

Fontana, Federica. La villa romana di Barcola: A proposito delle villae maritimae della regio $X$. Roma: Quasar, 1993.

Gaffney, Vincent, and Zoran Stančić. »Predicting the Past: GIS and Archaeology. $\ll G e-$ oinformation-Systems 4 (1991): 27-32.

Gaffney, Vincent, Zoran Stančić, and Helen Watson. »The Impact of GIS on Archaeology: A Personal Perspective.« In Archaeology and Geographical Information Systems: A European Perspective, edited by Gary Lock and Zoran Stančić, 21I-29. London: Taylor \& Francis, 1996.

Gaffney, Vincent, Zoran Stančić, and Helen Watson. >Moving from Catchments to Cognition: Tentative Steps Toward a Larger Archaeological Context for GIS.«Anthropology, Space and Geographic Information Systems (1996), 132-54.

Gluščević, Smiljan, and Narcisa Bolšec Ferri. »Izvješće o podmorskim arheološkim radovima u Katoru kod Umaga.« Obavijesti Hrvatskog arheološkog društva I (2003): II $4-20$.

Gnirs, Anton. »Überreste römischen Ansiedlungen in der Gegend zwischen Pola und Rovigno.«Mitteilungen der K. u K. Zentralkommission zur Erforshung und Erhaltung der Baudenkmäle 27 (190I): 128-30.

Gnirs, Anton. »Forschungen über antiken Villenbau in Südistrien.« Jahreshefte des Österreichischen Archäologischen Instituts I8 (1915): 99-164.

Hudec, Goran, and Vlasta Begović. »Istraživanja areala rezidencijalnog kompleksa palače u uvali Verige na Brijunima - digitalnom obradom i analizom aerofotografija metodom linearne modifikacije histograma.« Obavijesti Hrvatskog arheološkog društva 3 (1993): 59-62.
Hudec, Goran, and Vlasta Begović. »Mogućnosti primjene digitalne obrade aerosnimaka u pripremi arheoloških istraživanja.« Bilten Savjeta za daljinska istraživanja ifotointerpretaciju HAZU I2 (1993): 77-83.

Jurkić Girardi, Vesna. »Scavi in una parte della villa rustica romana a Cervera porto presso Parenzo.«Atti Centro recherché Storiche di Rovigno (1979): 427-38.

Jurkić Girardi, Vesna. »Građevinski kontinuitet rimskih gospodarskih vila. « Histria $\mathrm{Hi}_{\text {- }}$ storica 4, no. 2 (198I): 70-IO5.

Jurkić Girardi, Vesna. »Archaeological Researches of the Marittime Roman/Late Roman Villa on the Vižula Peninsula (Isola del vescovo) near Medulin in 2006 and 2007.《 Histria Antiqua Is (2007): 473-78.

Jurkić Girardi, Vesna. »Le antique hearths in the roman residential villa on the Vižula peninsula near Medulin.« Histria Antiqua I6 (2008): I6I-68.

Kovačić, Vladimir, Antonio Marchiori, Yolande Marion, Guido Rosada, Corinne Rousse, and Francis Tassaux. »Loron-lorun, Parenzo-Poreč, Istria. Una Villa Maritima nell'agro parentino: La campagna di ricerca 2010.«Histria Antiqua 20 (2011): 515.

Lafon, Xavier. Villa Maritima. Paris: Boccard, 2001.

Lipovac Vrkljan, Goranka. »Keramičarska radionica u Crikvenici / Ceramics Workshop in Crikvenica.« In International Archaeological Symposium: Sumaries of Reports, 64-5, I53. Pula: 2006.

Matijašić, Robert. Gospodarstvo antičke Istre. Pula: $\gg$ Žakan Juri«, 1998.

Meder, Jagoda. Podni mozaici u Hrvatskoj. Zagreb: Ministarstvo kulture Republike Hrvatske, Uprava za zaštitu kulturne baštine, 2003.

Pliny the Elder. Natural History (Naturalis Historia), LCL. Cambridge: Harward University Press, 1942.

Pliny the Younger. Epistulae. Bloomington: Indiana University Press, 1962. 
Schrunk, Ivančica, and Vlasta Begović. »Roman estates on the island of Brioni, Istria.« Journal of Roman Archaeology I3 (2000): $253-76$.

Schwalb, Hans. Römische villa bei Pola. Wien: Hölder, 1902.

Soren, David, and William Aylward. »Dazzling Spaces.« Archaeology 47, no. 4 (1994): 248.

Starac, Alka. »Carski posjedi u Histriji.«Opuscula Archeologica I8 (1995): 133-45.

Suić, Mate. Antički grad na istoćnom Jadranu. Zagreb: Golden marketing, 2003.

Tassaux, Francis. »Laecanii, recerches sur une famille senatoriale d' Istrie.« Mélanges de l'Ecole française de Rome: Antiquité 94 (1982): 227-69.

Tassaux, Francis, Robert Matijašić, and Vladimir Kovačić. Loron (Croatie). Bordeaux: Ausonius, 200I.

Terrenato, Nicola. »The Auditorium site in Rome and the origins of the villa.« Journal of Roman Archaeology I 4 (200I): 5-32.

Verzar Bass, Monika. »Le transformazioni agrarie tra Adriatico nordorientale e Norico.«In Società Romana e impero tardoantico, edited by Andrea Giardina, 647-883. Roma: Editori Laterza, 1986.

Vetters, Wolfgang, and Heinrich Zabehlicky. »Eine Klimakatastrophe um 200 n. Chr. und ihre archäologishe Nachweisbarkeit.« In Archäologie - Naturwissenschaften Umwelt: Beiträge der $A G \gg$ Römische Archäologie« auf dem 3. deutschen Archäologenkongres in Heidelberg, edited by Norbert Hanel and Martin Frey, 9-I2. Oxford: Archaeopress, $200 \mathrm{I}$.

Wheatley, David, and Mark Gillings. The Archaeological Applications of GIS: Spatial Technology and Archaeology. London: Taylor \& Francis, 2002.

Whittaker, C. R. »The Consumer City Revisited: The Vicus and the City.« Journal of Roman Archaeology 3 (1990): 110-18.
Zaninović, Marin. »Villae rusticae u pejsažu otoka i obale antičke Dalmacije.« Histria Antiqua I (1995): 86-96. 


\title{
Ricerche del 2008-2010 nella villa maritima di San Simone/Simonov zaliv presso Isola/Izola (Slovenia)
}

\author{
Stefan Groh and Helga Sedlmayer
}

In the villa maritima of Simonov zaliv near Izola (Slovenia) new archaeological research were carried out in the years 2008-20I0. Apart from new mappings of visible building remains, the installation of a GIS-project and geophysical measurements, excavations were conducted in two areas of the villa. In 2008 the archaeological research was focused on the building complex in the north, in 2009-2010 a part of the porticus near the port was excavated. The results of the stratigraphical excavations and analyses of finds give important new information about the chronology and building concept of the villa during the $\mathrm{I}^{\mathrm{st}}$ century BC and the $\mathrm{I}^{\mathrm{st}}$ century AD.

Keywords: villa maritima, San Simone/Simonov zaliv, excavations, analysis of finds, chronology

N

ella villa maritima di San Simone/Simonov zaliv, presso Isola/Izola sulla costa adriatica della Slovenia, sono iniziate delle ricerche sistematiche, grazie ad una cooperazione di ricerca tra l'Inštitut za dediščino Sredozemlja der Znanstveno-raziskovalno središče Koper Univerze na Primorskem (UP ZRS) e l>Österreichisches Archäologisches Institut Wien (ÖAI). Scopo di questo accordo di cooperazione è di acquisire nuove conoscenze circa la topografia, le strutture edilizie e la cronologia relative alla villa. Di seguito si presentano i risultati delle prime campagne di ricerca 200820I0, ottenuti con $1>$ installazione di un sistema geoinformativo e di misurazioni geodetiche dei resti scavati e restaurati nel XX secolo, con misurazioni geofisiche e con scavi stratigrafici mirati.
Indagini archeologiche sistematiche nella villa ebbero luogo negli anni Venti del XX secolo, sotto la direzione di Attilio Degrassi e di Bruna Tamaro e negli anni Cinquanta sotto quella di Vinko Šribar. Nella seconda meta del XX secolo furono effettuati mappature dei moli subacquei nel bacino portuale, le prime misurazioni geofisiche e scavi archeologici da Giordano Labud sotto la direzione di Marko Stokin. ${ }^{2} \mathrm{Nel}$

Attilio Degrassi, »Tracce di Roma sulla spiaggia di San Simone, « Archeografo Triestino Io, no. 3 (1923).

2 Michael Donderer, Die Chronologie der römischen Mosaiken in Venetien und Istrien bis zur Zeit der Antonine (Berlin: Mann, 1986); Elica Boltin-Tome, $\gg$ Arheološke najdbe na kopnem in na morskem dnu v Viližan in Simonovem zalivu v Izoli,« Annales I (1991); Federica Fontana, La villa romana di Barcola: A proposito delle Villae Maritimae della Regio X (Roma: Quasar, 1993); Giordano Labud, »Studio tipilogico di reperti anforici rinvenuti nel sito archeologico romano di San Simone (Simonov zaliv), nell'Istria settentrionale, « Opuscula romana 20 (1996); Iva Mikl Curk, »Simonov zaliv - Terra Sigillata from the First Field Campaigns, « Opuscula romana 20 (1996); 
2006 Branko Mušič effettuò misurazioni geofisiche (particelle I419-1429).

La villa maritima di San Simone/Simonov zaliv si trova su una penisola oggi larga circa 120 $\times$ I50 $\mathrm{m}$ e possiede nella parte sudoccidentale un porto provvisto di due moli della grandezza di circa $7400 \mathrm{~m}^{2} .{ }^{4}$ La parte nordorientale della penisola è delimitata da un ruscello, a sud della penisola, ed a est dei moli, si trovava una depressione del terreno, minacciata dalle inondazioni. Tra gli scavi del 1922 e quelli della metà del XX secolo la riva fu asportata dal mare in questo punto per una lunghezza di $15-20 \mathrm{~m} ;{ }^{5}$ in seguito a tale evento, nel $1968 \mathrm{fu}$ disposto un argine fino al molo romano meridionale. Questi terrapieni e l'originario andamento della costa si riconoscono grazie alle foto più vecchie ${ }^{6} \mathrm{e}$ in base alle prospezioni geofisiche, condotte dall'ÖAI 2008.

Scopo degli scavi del 2008-20ı0 è stato quello di acquisire nuove e sicure informazioni sulla cronologia della villa e di verificare i dati delle prospezioni geofisiche, condotte da B. Mušič e dall'ÖAI. Secondo le prospezioni geofisiche a un corpo in parte già scavato a nord segue una costruzione simile a un corridoio largo circa $6 \mathrm{~m}$ intorno a un cortile ampio almeno $27 \mathrm{~m}$. Questo poi porta a una porticus, parzialmente indagata, nella parte meridionale della villa. ${ }^{7}$

\section{Ricerche tra il complesso edilizio a nord e a sud della villa}

Gli scavi del 2008 si sono estesi su una superficie di oltre $3 \times 8 \mathrm{~m}$, ovvero $24 \mathrm{~m}^{2}$, congiungendosi sia agli scavi anteriori nel complesso edilizio a

Snježana Karinja, »Dve rimski pristanišči v Izoli,« in Arheoloska istraživanja u Istri, ed. Božidar Čečuk, (Zagreb: Hrvatsko arheološko društvo, 1997); Marina De Franceschini, Le ville romane della Regio X (Venetia et Histria) (Roma: »L'Erma « di Bretschneider, 1998); Marko Stokin, Simonov zaliv: Antična vila « Annales, Series historia et sociologia $\mathrm{I}$, no. I (2001).

3 Branko Mušič, Poročilo o geofizikalni raziskavi: Izola - Simonov zaliv (Ljubljana: Inedito rapporto di prospezione, 2006).

4 Attilio Degrassi, »I porti romani dell’Istria, « in Scritti di Archeologia e di Antichità Classiche in onore di Carlo Anti (Firenze: Sansoni, 1955).

Vinko Sribar, »Constatations archéologico-topographiques dans la baie de Simon près d'Izola, «Arheoloski Vestnik 9-10 (1958-1959).

6 Karinja, Dve rimski pristanišči v Izoli.

7 Stokin, Simonov zaliv; Poroćilo o geofizikalni raziskavi. nord della villa che a un contesto della costruzione meridionale.

I risultati dell'indagine archeologica $2008^{8}$ permettono di articolare la storia edilizia dell'area di scavo in quattro periodi, che descrivono attività con forte impatto sull'ambiente e sulle strutture edilizie.

Nel periodo i ha luogo la preparazione del cantiere e la predisposizione di spianamenti allo scopo di ottenere un livello il più possibile unitario. Dal livello di partenza e di lavoro (periodo I.I-2) comincia la costruzione delle fosse e dei muri di fondazione (periodo I.3).

Nel periodo 2 segue alla costruzione dei muri la sistemazione dei vani $(\mathrm{A}-\mathrm{C})$. Il vano $\mathrm{A}$ a nord è largo 4, I $\mathrm{m}$ (da nord a sud) e largo per lo meno $3 \mathrm{~m}$. I rinvenimenti del periodo d'uso sono documentabili solo in pochi casi a causa delle numerose fosse, cronologicamente più recenti, e di quelle relative all'orizzonte di abbandono (periodo 3). Del pavimento a mosaico bianco del vano A rimane appena una superficie di $0,06 \mathrm{~m}^{2}$. Dal punto di vista della tecnica di costruzione il vano A appartiene al complesso edilizio settentrionale della villa messo parzialmente in luce da Attilio Degrassi, cui corrisponde anche per l'arredo di qualità con pavimenti musivi.

Gli ambiti B e C risultano dall'aggiunta del

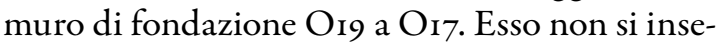
risce ad angolo retto, ma ha, come tutte le strutture scavate nel corpo meridionale della villa, un orientamento divergente di circa $5^{\circ}$ verso ovest. Nell'area B si costruisce un pozzo nero $\left(\mathrm{O}_{2} \mathrm{O}\right)$, parzialmente rimesso in luce nell'angolo sudoccidentale dello scavo.

Nel periodo 3 sono abbandonati i vani scavati. Questo abbandono procede di pari passo con il reimpiego del materiale da costruzione (blocchi dell'opera muraria, pavimenti mosaicati). La spoliazione della villa che portò al suo abbandono sembra esser stata sistematica.

8 Stephan Groh and Helga Sedlmayer, »Die Grabungen in der römischen Villa maritima von San Simone/Simonov zaliv bei Isola/ Izola, Slowenien, « Annales, Series historia et sociologia 18 no. 2 (2008); Stephan Groh and Helga Sedlmayer, »Nuove ricerche nella villa maritima romana di San Simone/Simonov zaliv presso Isola/Izola (Slovenia), «Aquileia Nostra 80 (2010). 
Il periodo 4 corrisponde al degrado postantico ovvero all'uso agricolo del terreno.

Circa 400 reperti sono considerati significativi dalla sezione di scavo dell'anno 2008. La metà di essi proviene dagli strati che stanno in rapporto immediato con le preparazioni, con I'utilizzo e con l'abbandono del complesso. L'altro 50 per cento viene dai livelli che furono alterati oppure distrutti in epoca postantica; in questo caso compaiono numerosi residui antichi accanto a un numero ridotto di rinvenimenti della prima età moderna e di epoca contemporanea.

\section{Ricerche nel complesso edilizio a sud della villa}

Per chiarire le fasi costruttive nella zona della porticus nel 2009-2010 si attuò un saggio di scavo ad oriente dell'area di scavo già indagata da M. Stokin. I livelli antichi erano stati disturbati dalle molteplici attività di scavo del recente passato e tagliati all'inizio dell'età moderna da un sentiero, che congiungeva San Simone con il porto. Nonostante ciò, i resti antichi della porticus furono rinvenuti in buon stato di conservazione. Ciò è dovuto al fatto che l'obliterazione delle costruzioni del I sec. d.C. fu realizzata attraverso sistematici lavori di riporto e livellamento.

Prima della costruzione della porticus l'area vicino al porto fu usata per lo scarico di rifiuti. Diversi strati di riporto, contenenti per lo più resti di anfore, sono stati messi in luce sotto il livello di impianto della poticus. Queste azioni permisero di livellare l'iniziale forte dislivello del terreno.

La porticus ha due fasi. Nella prima fase questa era pavimentata a mosaico, nella seconda furono eretti sul lato meridionale del muro nord dei pilastri di pietra, legata da malta. Essi furono impiantati direttamente sul pavimento in mosaico. L'analisi delle strutture del portico, messe in luce negli scavi del 2009-2010, e dei materiali rinvenuti indicano che il complesso non è stato costruito prima dell'età tiberiana. Gli interventi edilizi nell'area del portico sono dunque più recenti di quelli effettuati nell'adiacente zona nord, che è stata edificata tra il 25 ed il ıo a.C.

Da un lato l'abbandono sistematico delle costruzioni e lo smontaggio dei materiali edilizi è dimostrato dal prelievo perfino delle tessere di mosaico. Dall'altro i strati di livellamento con mattoni e pietre sopra i resti delle antiche costruzioni indicano il cambiamento di funzione dell'area nell'antichità.

\section{Interpretazione e discussione dei rinvenimenti degli scavi}

2008-2010

Il tipo architettonico della villa marittima, che comprende concettualmente portici molto sporgenti, nasce in Italia nel secondo quarto del I secolo a.C.' La penisola, su cui si trova Ia villa maritima di San Simone, fu coperta da costruzioni fino al ruscello, che scorre a nordest. Muri isolati sono stati trovati anche a sud e a sudest dei moli del porto. ${ }^{\mathrm{r}} \mathrm{Da}$ ciò si potrebbe concludere che uno o più edifici principali erano situati nella penisola, ed erano fiancheggiati da un portico fino al porto. La costruzione del complesso edilizio settentrionale, cioè di un edificio principale della villa, può essere fissata con sicurezza sulla base dello scavo 2008 al periodo intorno al 25-10 a.C. La costruzione fa seguito a consistenti interventi di livellamento.

Le strutture note mediante scavi e misurazioni geofisiche indicano nella parte settentrionale e meridionale della penisola due complessi edilizi a est del porto. ${ }^{\text {II }}$ A nord è riconoscibile una fitta edificazione e, per il settore oggetto di scavo, è possibile individuare vani di alto valore qualitativo (pavimenti musivi, pitture murali); cosi il vano A, indagato nel 2008 , rivela il resto di un pavimento musivo bianco. Il complesso edilizio settentrionale di circa $40 \times 50 \mathrm{~m}$ possiede una corte interna, di circa $15 \times 22 \mathrm{~m}$, circondata da un portico. La costruzione si estende

\footnotetext{
9 Xavier Lafon, Villa Maritima (Roma: École Française de Rome, 200I); Vlasta Begović Dvoržak and Ivančica Dvoržak Schrunk, »Roman Villas in Istria and Dalmatia, Part III: Maritime Villas, « Prilozi Instituta za arheologiju u Zagrebu 2 I (2004)

Io Vinko Šribar, »Izola,«Varstvo Spomenikov 12 (1969).

I I Mušič, Poroćilo ogeofizikalni raziskavi.
} 
fino al molo marittimo. II complesso, già scavato sotto la direzione di Attilio Degrassi, oggi visibile per una superficie di $13,8 \times 18,3 \mathrm{~m}$, si trova nell'angolo meridionale di questo fabbricato settentrionale.

Nella parte meridionale della penisola è localizzato un altro complesso edilizio. Esso si compone di una grande corte interna di almeno $17 \times 36 \mathrm{~m}$ e di un portico. Singoli vani fiancheggiano a nord, ovest e sud la corte interna. La porticus è costituisce un passaggio verso il porto con vista sul mare. Il complesso edilizio misura almeno $44 \times 53 \mathrm{~m}$, ma la terminazione verso est non è nota. Nell >ambito di questo complesso meridionale si trova la corte (area B) con il pozzo nero, indagato nel 2008 , che è da interpretare come area produttiva. L $>$ appendice obliqua e la tecnica costruttiva del muro Oıg e dei vani intorno al portico meridionale, divergente del complesso settentrionale, indicano due differenti corpi di fabbrica. Il corpo meridionale diverge nel suo orientamento di circa $5^{\circ}$ verso ovest da quello settentrionale. Entrambi sono stati costruiti in una successione cronologica relativamente vicina e potrebbero aver avuto forse anche diversa funzione fra loro. I rinvenimenti degli scavi 2008 confermano ampiamente i dati relativi alle aree riconosciute come edificate nelle misurazioni geofisiche da B. Mušič e dall>ÖAI.

Negli ultimi 2000 anni il livello del mare si è innalzato di circa $1,6 \mathrm{~m}$, ciò significa che i resti dei moli marittimi che oggi giacciono al di sotto della superficie del mare e i muri di fondazione sulla terraferma, originariamente si trovavano sicuramente ad altezza maggiore rispetto al livello del mare. ${ }^{12}$ I pavimenti dell'edificio a nord della villa si trovano oggi circa I, $4 \mathrm{~m}$ sopra il livello del mare, il che corrisponde ad una altezza di circa 3 $\mathrm{m}$ sul livello del mare in epoca romana. La porticus e i vani nella parte meridionale della villa si trovano attualmente a I,I $\mathrm{m}$ al di sopra del livello

I2 Fabrizio Antonioli, Marco Anzidei, Kurt Lambeck, Rita Auriemma, Dario Gaddi, Stefano Furlani, Paola Orrù, Emanuela Solinas, Andrej Gaspari, Snježana Karinja, Vladimir Kovačić, and Luciano Surace, »Sea-level Change during the Holocene in Sardinia and in the Northeastern Adriatic (Central Mediterranean Sea) from Archaeological and Geomorphological Data, « Quaternary Science Reviews 26 (2007) del mare, quindi a un'altezza di circa 2,7 $\mathrm{m}$ sopra di esso in epoca romana. La differenza di quota tra l'edificio principale a nord e Ia porticus a sud arriva dunque a circa $0,3 \mathrm{~m}$.

La dismissione per lo meno di parte della villa si data sulla base dei dati degli scavi 20082010 verso la metà ovvero il terzo quarto del I secolo d.C. ( $50-70$ d.C.). E verosimile che gran parte del corpo settentrionale oppure forse anche dell'intero edificio principale sia stato abbandonato in quest'epoca. Questo potrebbe essere avvenuto in conseguenza di cause endogene (terremoto, maremoto o burrasche). Labbandono procede di pari passo con il reimpiego di materiale da costruzione, che in termini di cronologia assoluta ebbe luogo immediatamente dopo l'abbandono dell'edificio. L'opera sistematica di spoglio nel complesso edilizio a nord e nella porticus porta a concludere l'esistenza di interventi edilizi nelle immediate vicinanze. Lo attesta il materiale finora pubblicato rinvenuto negli scavi più vecchi nell'ambito del portico e del porto, che indica un uso di queste aree ancora nel IIl secolo d.C. ${ }^{\text {I3 }}$

\section{Summary}

Due to the topographical situation and the geophysical and archaeological findings the villa maritima of Izola/ Isola - Simonov zaliv/San Simone, situated on a peninsula, can be divided into one or more principal buildings and a portico next to the harbour.

The construction of the northern building with superbly furnished rooms, a main building of the villa, can be dated, following the results of the excavation in 2008 , in the time around $25-10 \mathrm{BC}$. The construction is carried out after extensive levelling measures.

In the south of the peninsula there is another building with a courtyard and portico, built on the passage to the harbour with sea views.

The southern structure differs in its orientation by 5 to the west from that of the northern building. The two structures have been built in a relative chronological sequence of each other. The construction of the portico in the south near the harbour is about one generation later than the construction of buildings in the north.

I3 Mikl Curk, Simonov zaliv 
The abandonment of at least parts of the villa dates, according to the results of the excavation in 2008 and 2010 around the middle or in the third quarter of the $\mathrm{I}^{\mathrm{st}}$ century AD (50-70 AD). The abandonment could be caused by endogenous influences, i.e. earthquakes or thunderstorms.

After leaving these structures of the villa, building materials (mosaic floors, walls, roof-tiles) were torn out systematically. This re-use of building material can be dated in the time immediately after the abandonment. The systematic stone robbery indicates hypothetically that the reconstruction work took place in the vicinity to the harbour, which was still in use.

\section{Povzetek}

Zaradi topografske situacije ter geofizikalnih in arheoloških najdb je mogoče obmorsko vilo v Simonovem zalivu, ki se nahaja na polotoku, razdeliti na eno ali več glavnih stavb ter stebrišče ob pristanišču.

Na podlagi rezultatov izkopavanj leta 2008 je mogoče gradnjo severne stavbe s čudovito opremljenimi prostori, tj. glavno stavbo vile, datirati v čas ok. 25-10 pr. Kr. Gradnja se je začela šele po obsežnih izravnavah terena. Na jugu polotoka je še ena stavba z dvoriščem in stebriščem, zgrajena na prehodu v pristanišče s pogledom na morje.

Lega južne strukture glede na severno odstopa za $5^{\circ}$ bolj zahodno. Obe strukturi sta bili zgrajeni v relativnem kronološkem zaporedju, konstrukcija stebrišča na jugu v bližini pristanišča pa je bila zgrajena približno eno generacijo pozneje kot je bila zgrajena stavba na severu.

Glede na rezultate izkopavanj v letih 2008 in 2010 je bila vila zapuščena ok. sredine ali v tretji četrtini I. stoletja (50-70 po Kr.). Zapuščanje bi lahko povzročili endogeni vplivi, tj. potresi ali nevihte.

Po opustitvi struktur so bili sistematično odstranjeni gradbeni materiali (mozaična tla, stene, strešne ploščice); ponovno uporabo gradbenega materiala je mogoče časovno umestit takoj po opustitvi. Sistematični ropanje kamna hipotetično kaže na to, da so se obnove dogajale v bližini pristanišča, ki je bilo še vedno v uporabi.

\section{Abbreviations}

Cassani $=$ Cassani, 1991

Conspectus = Ettlinger et al., 1990

Lamboglia = Lamboglia, 1952
$\mathrm{O}=($ Befund)objekt

ÖAI = Österreichisches Archäologisches Institut

Olcese $=$ Olcese, 2003

ZRS = Znanstveno-raziskovalno središče

\section{Bibliography}

Antonioli, Fabrizio, Marco Anzidei, Kurt Lambeck, Rita Auriemma, Dario Gaddi, Stefano Furlani, Paola Orrù, Emanuela Solinas, Andrej Gaspari, Snježana Karinja, Vladimir Kovačić, and Luciano Surace. »Sea-level Change during the Holocene in Sardinia and in the Northeastern Adriatic (Central Mediterranean Sea) from Archaeological and Geomorphological Data.« Quaternary Science Reviews 26 (2007): 2463-486.

Begović Dvoržak, Vlasta, and Ivančica Dvoržak Schrunk. »Roman Villas in Istria and Dalmatia, Part III: Maritime Villas.« Prilozi Instituta za arheologiju u Zagrebu 2I (2004): 65-90.

Boltin-Tome, Elica. »Arheološke najdbe na kopnem in na morskem dnu v Viližan in Simonovem zalivu v Izoli.« Annales I (199I): $5 \mathrm{I}-58$.

Cassani, Giovanna. »La ceramica della US ı 100 della villa di Pavia di Udine: Relazione preliminare sulla rozza terracotta.« Quaderni Friulani di Archeologia I (I99I): 89-102.

De Franceschini, Marina. Le ville romane della Regio X (Venetia et Histria). Roma: »L'Erma $\ll$ di Bretschneider, 1998.

Degrassi, Attilio. »I porti romani dell'Istria.« In Scritti di Archeologia e di Antichità Classiche in onore di Carlo Anti, 119-69. Firenze: Sansoni, I955.

Degrassi, Attilio. $\gg$ Tracce di Roma sulla spiaggia di San Simone.« Archeografo Triestino Io, no. 3 (1923): 329-4I.

Donderer, Michael. Die Chronologie der römischen Mosaiken in Venetien und Istrien bis zur Zeit der Antonine. Berlin: Mann, 1986. 
Ettlinger, Elisabeth, Bettina Hedinger, Bettina Hoffmann, Philip Kenrick, Giuseppe Pucci, Katrin Roth-Rubi, Gerwulf Schneider, Siegmar von Schnurbein, Colin Wells, and Susanne Zabehlicky-Scheffenegger. Conspectus Formarum Terrae Sigillatae Italico Modo Confectae. Bonn: Habelt, 1990.

Fontana, Federica. La villa romana di Barcola: A proposito delle Villae Maritimae della Regio X. Roma: Quasar, 1993.

Groh, Stephan, and Helga Sedlmayer. »Die Grabungen in der römischen Villa maritima von San Simone/Simonov zaliv bei Isola/Izola, Slowenien.«Annales, Series historia et sociologia 18 no. 2 (2008): 385-96.

Groh, Stephan, and Helga Sedlmayer. »Nuove ricerche nella villa maritima romana di San Simone/Simonov zaliv presso Isola/Izola (Slovenia).« Aquileia Nostra 80 (2010): II3-25.

Karinja, Snježana. »Dve rimski pristanišči v Izoli.« In Arheološka istraživanja u Istri, edited by Božidar Čečuk, I77-92. Zagreb: Hrvatsko arheološko društvo, 1997.

Labud, Giordano. »Studio tipilogico di reperti anforici rinvenuti nel sito archeologico romano di San Simone (Simonov zaliv), nell'Istria settentrionale.« Opuscula romana 20 (1996): 254-60.

Lafon, Xavier. Villa Maritima. Roma: École Française de Rome, 200I.

Lamboglia, Nino. »Per una classificazione preliminare della ceramica campana.« In Atti del primo Congresso internazionale di Studi Liguri 1950, 139-206. Bordighera: Stabilimento Tipigrafico Cune, 1952.

Mikl Curk, Iva. »Simonov zaliv - Terra Sigillata from the first field campaigns. «Opuscula romana 20 (1996): 249-53.

Mušič, Branko. Poročilo o geofizikalni raziskavi: Izola - Simonov zaliv. Ljubljana: Inedito rapporto di prospezione, 2006.

Olcese, Gloria. Ceramiche comuni a Roma e in area romana: produzione, circolazione e tecnologia. Mantova: Società Archeologica Padana, 2003.
Stokin, Marko. »Simonov zaliv: Antična vila.« Annales, Series historia et sociologia II, no. I (200I): 405-I2.

Šribar, Vinko. »Constatations archéologico-topographiques dans la baie de Simon près d'Izola.« Arbeološki Vestnik 9-Io (19581959): 27I-77.

Šribar, Vinko. »Izola.« Varstvo Spomenikov I2 (1969): 89-91. 


\title{
Cultural Route of Stonemasons and Stones in the Adriatic:
} A Conceptual Proposal for the Interpretation and Promotion
of Cultural Heritage in Limestone along the Adriatic coast

\author{
Neža Čebron Lipovec and Katarina Šmid
}

Contemporary heritage interpretation trends, aims of alternative and creative tourism as well as recommendations by the European Council regarding the promotion of European values and the diverse European identity form the framework of the present paper which introduces the conceptual proposal for a new European Cultural Heritage Route of "Stonemasons and Stones in the Adriatic region". Departing as a follow-up activity of passed EU IPA Adriatic projects, the proposal indicates a comprehensive strategy for capitalising the existing knowledge on stonecrafts in the Adriatic and its specific role as transregional and transnational connector.

Keywords: European Cultural Routes, stonemasons, stone, heritage interpretation, tourism

The following Conceptual Proposal for the Interpretation and Promotion of Cultural Heritage and Limestone along the Adriatic was based and elaborated not only as the continuation and the progress of the knowledge and results that were gained through the implemented activities within the Work Package 4 - Platy Limestone as Cultural Heritage of the RoofOfRock project (IPA Adriatic CBC Programme 2007-2013), but also on the experiences and good practices regarding the cultural heritage and especially its interpretation gained through the other international projects, which were carried through the University of Primorska (see Chapter VII).

The Proposal is in line with the principles and objectives of the European Agenda for Cul- ture (issued by European Commission in 2007) and with the modern heritage interpretation trends in Europe, as promoted by the European Association for Heritage Interpretation (Interpret Europe). ${ }^{2}$

The modern heritage interpretation encourages an approach to the non-formal education that passes the ideas, knowledge and stories about the historic site, buildings, museum exponats or other cultural heritage monument (of tangible and intangible heritage) to the general public and random visitors. The basic idea is that sightseers should perceive interpretation that would enhance their own interpretations of heritage, but they should not feel like being instructed like „in school“. The deeper meanings and in-

Official Journal of the European Union, 29. I I. 2007.

http://www.interpret-europe.net/. 
sights should be revealed by first-hand, hands-on experience and by illustrative media rather than by old-fashioned factual information that will soon be forgotten. On the one hand, one of the main objectives of heritage interpretation is to motivate the audience, to raise and fulfil its expectations, on the other hand, in a long-term setting, contemporary trends in interpretation seek to promote awareness raising through a diversified and plural understanding of heritage and the continual evolution of its significances and values.

The need for new educational trends and modern approaches to heritage interpretation has developed hand in hand with new technology and reasonably priced travelling. Without the sufficient heritage presentation too many trippers just leave the site without a deeper experience. In this sense, heritage interpretation can have a major impact in contributing to the promotion of alternative tourist itineraries, offering at the same time a rich variety of hands-on activities as promoted by „creative tourism“.

To fulfil the gap in the professional training courses of the staff - managers and educators in the cultural heritage, the project InHerit was started. Its fundamental goal is to educate the employees or volunteers to develop the good practices and full potentials in heritage interpretation that would result in enhanced learning through Europe's rich and diverse heritage and would make the heritage more accessible to tourists. $^{3}$

To sum up, in the last decades has became clear that only with the proper presentation of the heritage the visitors would broaden their horizons and promote the tangible and intangible heritage through first-hand experience among their relatives, friends or acquaintances.

\section{European Cultural routes}

Following the "European cultural convention" (1954), in 1987 the Council of Europe launched the "Cultural Routes programme" with the

http://www.interpretingheritage.eu/en.

4 http://www.culture-routes.net objective "to demonstrate, by means of a journey through space and time, how the heritage of the different countries and cultures of Europe contributes to a shared cultural heritage" (COE). The programme pursues, through an integrated common methodology, the putting into practice the fundamental principles of the Council of Europe, namely human rights, cultural democracy, cultural diversity and identity, dialogue, mutual exchange and enrichment across boundaries and centuries. Since 1988 the programme has been managed by an executive agency of the Council of Europe, assisted by the European Institute for Cultural Routes.

In order to acquire the certification of a Cultural Route, the submitted proposals for routes should meet a set of requirements, among which salient are:

I) The theme should be representative of European values and common to different European countries;

2) It should follow a historical route or a newly created route (in case of cultural tourism);

3) It should be the starting point of several future long-term and multilateral cooperation projects on different priority axes (scientific research; heritage conservation and enhancement; cultural and educational exchanges among young Europeans; contemporary cultural and artistic practices; cultural tourism and sustainable development);

4) It should be managed by an association or federation of associations, thus a network of independent organisations.

The first route to be awarded the title was the French pilgrimage road to Santiago de Compostela in Spain, or Way of St. James. The following other major routes also referred to the Medieval history of Europe: the French way between Rome and Canterbury, the routes of sites related to the Benedictine monastery of Cluny, the routes of St. Martin of Tours, the network between the Hanseatic cities on the Baltic sea, Transromanica - the Romanesque Routes of European Heritage, the Viking route. Progres- 
sively, routes from other chronological contexts were proposed too (ie. Mozart route), finally also routes, not-limited to a specific timeframe, were submitted, such as Routes of the Olive tree, Pottery routes ... It is in this later context that the idea of a "Cultural route of stonemasons and stone" found its background and support.

In December 2010, the Committee of Ministers of the Council of Europe adopted the Resolution $\mathrm{CM} / \operatorname{Res}(2010)_{53}$ that established an Enlarged Partial Agreement (EPA) which aimed at facilitating a tighter co-operation between states that could develop jointly the Cultural Routes. This agreement pursues similar objectives as the several European international calls for projects that address cultural heritage (various Interreg programmes, IPA Adriatic, Adrion, MED etc.), such as strengthening the potential of cultural heritage of the Cultural Routes for sustainable development, transnational co-operation and social cohesion. On a general level, the Cultural Routes programme places particular attention to topics concerning the symbolic meaning of European identity, unity, history, culture and shared values. On economic level, the programme has a major impact, or at least a potential for impact, on tourism. In this regard, it is foremost intended to develop lesser known destinations, also by pursuing the concept of alternative tourism and diversified and innovative tourist itineraries. Furthermore, the Cultural Routes can contribute to enhancement of "the democratic dimension of cultural exchange and tourism" by involving not only the local communities, grassroots networks and associations, but also the authorities on different levels (from local, regional to national). Finally, with its primary objective to contribute to the safeguarding and preservation of diverse heritage, it promotes the collaboration of academia and research institutions as well as heritage authorities with local authorities and communities in an interdisciplinary set-up.

Moreover, in 2010, the European Commission (EC) and the Council of Europe (CoE) jointly launched a study on European Cultur- al Routes and their impact on SMEs, in terms of innovation, competitiveness and clustering, especially their potential for a more sustainable tourism that promotes alternative and diversified tourist products, especially by promoting less known destinations. At the same time, the study sought to identify the potential that SMEs, involved in ECR, can have in fostering intercultural dialogue as well as the richness of European values and identity.

In order to be granted the status of a European Cultural Routes a phased procedure (Capp needs to be followed, fulfilling a set of criteria and requirements. Here we only list them, while the analysis for the specific case follows in the next chapter. In first place, eligibility criteria need to be met for the theme of the route itself. Secondly, the $\mathrm{CoE}$ stressed the priority fields of actions to be planned within the route's programme, namely : a) co-operation in research and development; b) enhancement of memory, history and European heritage; c) Cultural and educational exchanges of young Europeans; d) Contemporary cultural and artistic practice; e) Cultural tourism and sustainable cultural development. Finally, the networks that propose and take over the charge for the management of the Cultural Route's activities need to meet a set of criteria, among which they must involve several member countries and the conceptual framework needs to be based on prior research and supported by the different network partners.

\section{European Cultural Route of stonemasons and stones}

\section{in the Adriatic}

Considering the above framework, a "European Cultural Route of stonemasons and stones", starting in the eastern Adriatic - but not necessarily limited to it - becomes a realistic challenge. Taking into account the already existing comprehensive databases from former projects (ie. RoofOfRock, Revitas, Living landscape , AS - Archaeology for all, MACC, Dragodid...) , the key research material is already gathered and only needs to be eventually deepened 
so to provide a thorough mapping of historical stone trading paths and masons. It would be a recognizable route that links geology and cultural heritage in its concrete historic links (historic paths and routes of stonemasons, trade, ...) as well as through contextual links (architectural influences etc.). In the first phase, it would involve countries and partner institutions that participated in the above-mentioned projects, these are: Slovenia, Croatia, Bosnia and Herzegovina, Montenegro, Italy, and potentially also Albania and Greece. In a second phase, other countries where the stone (primarily limestone) from the Adriatic basin was exported, would join.

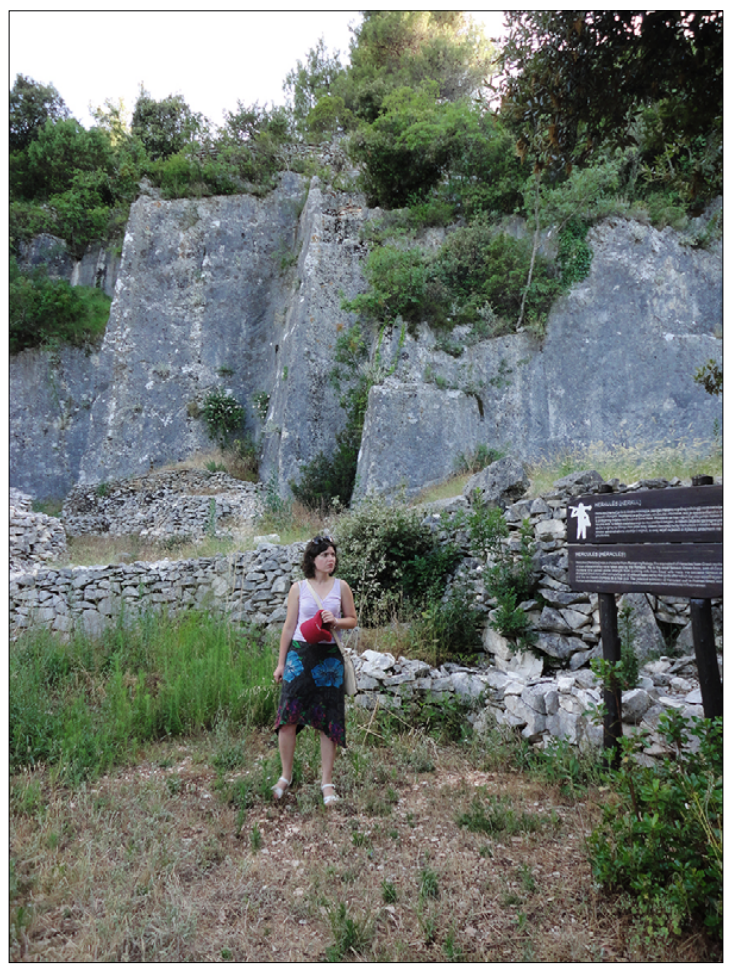

Fig.r: Former Roman quarry on the Dalmatian island of Brač. Photo: Andrej Preložnik 20I5.

The theme of the route relates to the historic exploitation and use of limestone which triggered a centuries-old craftsmanship that developed also through the exchange along the Eastern Adriatic coast as well as across the Adriatic sea to the Apennine Peninsula. Exploita- tion of local stone leads back to prehistory and the similarities of its first built structures that form the basis of the subsequent development. A strong network of the stonemasons' craft in the Adriatic is known ever since the Roman times (from Istria down to Dalmatia) (FIGURE I), in the Early Medieval period (with Istrian stone being used in Ravenna), but especially with the expansion of the Venetian Republic of Serenissima. It was since the early $14^{\text {th }}$ century that the Serensissima sent its stonemasons in Istria and Dalmatia to exploit its natural stone resources, so the stonemasons' production developed strongly in the $15^{\text {th }}$ century. To give a prominent example, we may look at the oeuvre of the renaissance stonemason capomastro Juraj Dalmatinac (or Giorgio Dalmata, Giorgio da Sebenico), one of the most prominent artists of the isth century Venetian Republic, famous as the author of the marvellous cathedral of St. James in Šibenik (in central Dalmatia, Croatia), but also for a number of works in Venice itself. Juraj Dalmatinac was also in charge for the exploitation in the quarry on the island of St. Hieronymus (part of archipelago of Brijuni) and its transport to Ancona. Similarly, the $16^{\text {th }}$ century master Jacopo Sansovino, among other author of the magnificent Libreria Marciana (in front of St. Mark's cathedral) in Venice also used the stone from Brijuni (FIGURE 2) and sites around Rovinj in Istria.

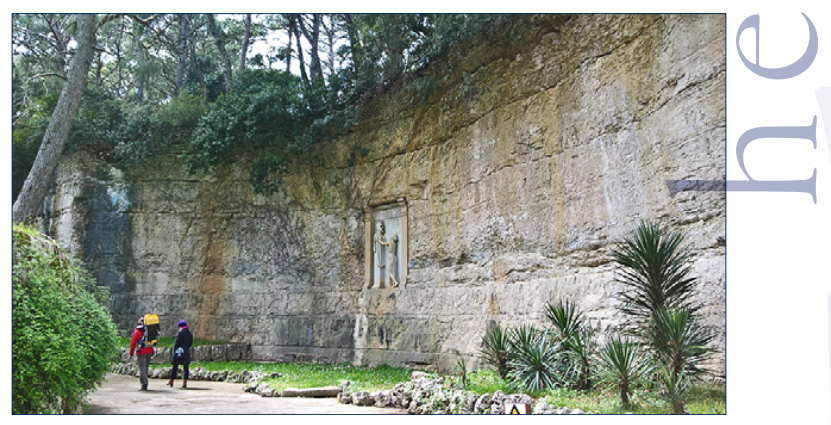

Fig.2: Former quarry at Brijuni, transformed into a park. Photo: Neža Čebron Lipovec 2016

The outstanding transregional meaning of the stonemasons' productions on smaller scale of Slovenian and Italian Kras/Carso was well- 
-appointed through the lifelong extensive work of Božidar Premrl, who published several professional books and booklets, articles and professionally made elaborates. Premrl has followed the tracks of the stonemasons' families and their workshops in Kras/Carso and has therefore clearly shown that the paths have developed disregarding the then territorial borders, but according to the natural assets and the well-off commissioners.

The route is thus constituted of show-case buildings, representing the architectural richness as well as the geological diversity along the Adriatic coast, but also of the links among the different sites. These can be related by their artistic and architectural heritage values, the practical use of stone, as well as geological specificities pointed out on selected show-case objects. Existing project's research results clearly highlight the common points (geological as well as architectonic stone elements) throughout the region and thus evidence its border-crossing role so to argument why can we call it cultural route. The route has a comprehensive interdisciplinary character as it equally considers the cultural heritage in its tangible (buildings) and intangible (stone crafts) manifestations as well as the connected natural settings (all natural landscape, but especially quarries). The activity is distinctively of transregional and transnational characteristics, as the stone, of which were built several monuments of architectural, artistic and cultural values, is a common material that disregards the borders and could be exported following the commissions.

As the path would follow trading paths, paths of masons etc., it presents a ramified setup or hierarchy of connections (local, regional, trans-regional). A back-bone route leads in the direction north-south from the Alps towards the Ionian sea, along the Eastern Adriatic coast, while transversal "vertebra" is attached to it. This is the trans-regional level. On regional and local level, the route is structured around key-centres, or "knots", of application of stone crafts: the centres are in fact urban centres (major cities or smaller-scale towns) with intense presence of representative show-case buildings, rich and diversified in the use of stone (building stone, cladding, ornaments). From here, visitors are directed in different directions: one continuation leads to nearby quarries or points of extraction, another continuation orients visitors towards other show-case sites or other local sites, meaningfully related to the quarry or its stonemasons. Among them, the "knots" are connected based on historic connections: following the routes that itinerant stonemasons and craftsmen took or the routes along which the stones were transported, also further away.

While the back-bone route can be the thread-line for a tourist package, the "secondary routes" represent a varied offer of daily itineraries. This way it meets the pursued and requested concept of alternative and diversified tourism. The main road and its ramification, as well as the show cases that lie by the road or other highlights of the architectural heritage, will be presented in the map that will be distributed to the tourist offices in the regions. (see Interpretation and presentation)

The definition of the main route in the Adriatic area and especially its broad ramification will highlight the common, well-beaten paths that were in the past chosen by the skilled stonemasons in order to commit the valuable commissions in the rich city centres or just to follow the stone trade in order to find some work.

To sum up, we may here just point out the key points where our conceptual proposal meets the official CoE's eligibility criteria for themes (Capp, 2006):

- The „Stonemasons' and stones' Cultural Route" is representative of European values, primarily of peaceful cultural exchange, coexistance and respect of diversity, and is thus common to several countries in Europe, namely Southern and SE Europe.

- The theme has already been researched and developed by groups of multidisciplinary experts from different regions of Europe 
as show the different European project of which it was the topic.

- „Stonemasons and Stones“ do represent an illustrative case of European memory, history and heritage since the memory of the pathways of itinerant craftsmans as well as the several surviving architectural show-cases are the result of historical micro-scale migrations, but due to the tight links between craftsmen and rich commissioners are also evidence of broad currents of civilisation and cultural development.

N $\quad$ - The proposed programme along the route does lend itself to cultural and educational exchanges of young people, namely through the several possibilities offered by the hands-on workshops.

- The proposal in itself already represents an initiative for an innovative project in the field of cultural tourism and sustainable cultural development.

- The route's programme is concieved as a lon-term multilateral co-operation project, involved in different field of action (equally in the co-operation in research and development as well as promoting cultural and creative tourism). Finally, it is to be set up by a multidisciplinary netowork located in different $\mathrm{CoE}$ states.

\section{Management of the route}

In first place, an adequate form for the management and cross-border collaboration should be defined. The best way for calibrated and fine-tuned activities, a network of delegated organisations should be set-up. In this concrete case, the already set-up network of the RoofOfRock show-case towns could be a starting structure, to which other organisations would join. In each region involved, one responsible organisation should be chosen, either from public organisations (universities, museums, heritage institutes etc.), associations or NGOs. The network organisations would then define its advisory board, the decision-making procedure, fields of action, responsibilities, funding resources and finally a 5 or 10 year management plan, including a jointly defined agenda of actions and activities, funding, PR and graphic design, strategic links with related stakeholders (tourist operators, tourism offices, public and private transport providers, ...).

In order to achieve its key objective - contribution to the conservation and dissemination of heritage values, the major common task of the network, however, resides in the interpretation of the ECR topic - this is the historical use of stone and its related routes.

\section{Interpretation and presentation}

In order to efficiently achieve a long-term implementation of the route and as well as to adhere to the official requests for ECR methodology, a well-considered interpretation should be devised, along with its infrastructure. For these purposes, we follow the international standards, pre-set by the "Ename Charter" on Interpretation and presentation of cultural heritage sites, promoted by ICOMOS in 2008.

Being every act of heritage conservation, also a communicative act, an Interpretation plan for the whole Route should be prepared. The task of interpretation is to "enhance personal experience, increase public respect and understanding, and communicate the importance of the cultural heritage sites" (Ename charter 2008, Principle I.I in Grobovšek 20I 4, 48), in our case the historic stonemasonry of the Adriatic is a physical proof for the transnational values of respect of multi-culturality as well as intercultural exchange and learning.

\section{Visual identity}

In order to communicate the connecting values of the route - the presence and historic use of stone - an easily identifiable logo and a visual identity, which would greet the traveller all throughout the route, should be designed. Clearly, it will have to be a concise and modern, highly recognizable image - to be used in all related promotional material. Most likely the ima- 
ge would refer to either stone as such, the stone-masons tools or built heritage in stone.

\section{Interpretive programme}

The interpretation programme is the top priority of the route thus it should be very carefully prepared with the participation of all the organisations involved, who, in turn, are responsible to collect updated data and material, based both on local and international scholarly research as well as through oral sources. The information provided in each marked point of the route should be clearly linked to those of other routes. The interpretive techniques would include both, traditional material technique - possibly used with the presence and use of stone - and advanced ICT technologies, the latter especially in places where interpretive infrastructure could obstruct the significance of the place.

In each selected location of the route, a key local itinerary, as a "branch" of the major route would be described, including the presentation of all related points of interest, buildings, open spaces, natural sites and quarries. All of them would be gathered in a map, which in turn again would be a part of the wholesome map of the route.

\section{Interpretive and didactic tools}

A map will help to tour operators to draw attention to the interesting objects in the vicinity, as well as to encourage the tourists (groups, individual visitors and hikers) to prolong their journey or to return to visit the more distant, but in some way related, heritage monuments, listed on the map.

As a complement to the map a booklet that will provide the short description of the objects and the links to the other stone products, made by the same stonemason or stonemasons' workshop, will be produced. The booklet is conceived as one of the main interpretive toolsand it works as a combination of a tourist guide of the whole route and of a diary. It would be composed also of a set of pre-defined empty pages where visitors would stick stickers or stamps from the different

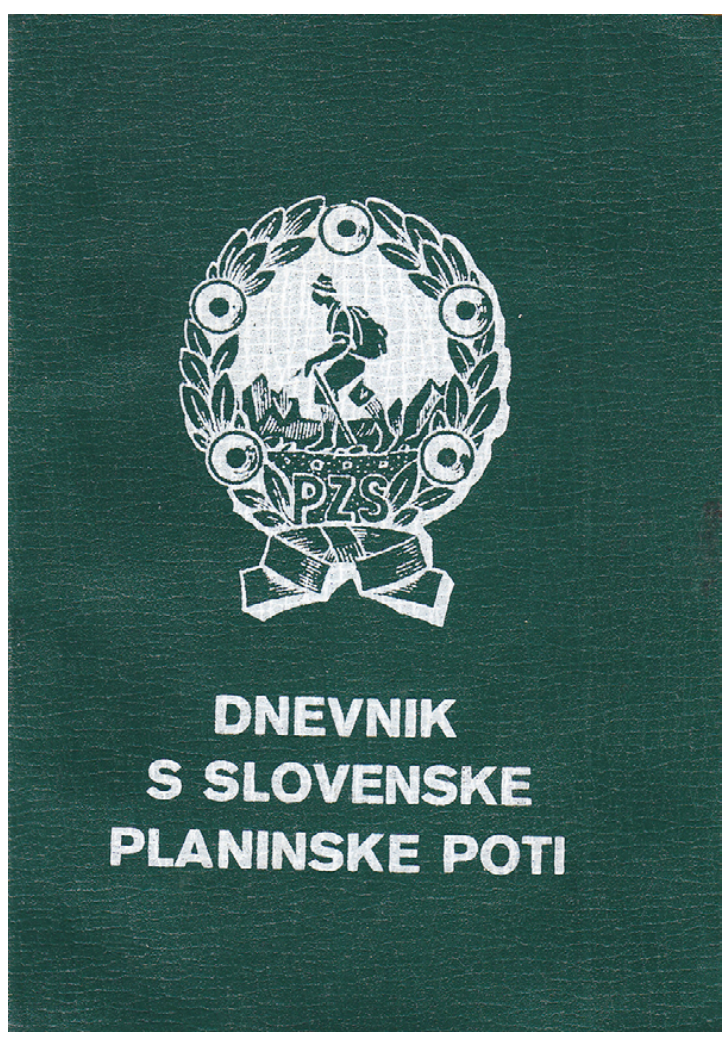

Fig. 3: Stamp-diary and kit of the Slovenian mountain-route "Slovenska planinska pot - transverzala". Photo: Neža Čebron Linovec 2016.

sites of the route. The idea of collecting stamps or stickers derives from the traditional Slovenian mountain diary or $\gg$ transverzala $\ll$ (FIGURE 3) where hikers collect the stamps at the peaks achieved, adding by hand the date. The booklet could be further elaborated also as a discount 
card where visitors showing this "ID" would get discounts either on merchandise or in cafes and restaurants. By having all the sites joint in one booklet, the transition among them would be enhanced, the visits increased and the connection between the heritage sites and their values highlighted.

Additionally, a specific cartoon-like book in national languages for kids (with drawings to be added etc.) would be designed as awareness-raising and educational material, again similar to the Slovenian mountain route, »transverzala« for kids.

To stimulate the participation of the local communities and storytelling, some points in the booklets could be formed as questions or enquiries for information that local inhabitants would provide. This way, different sources on heritage would be used, triggering "reflections on alternative historical hypothesis, local traditions and stories" (Ename Charter 2008, principle 2.2 in Grobovšek 2014, 49).

\section{Promotional material}

Linked to the cultural route, a whole set of promotional material or gadgets could be designed, reflecting the usual travelling aid (e. g. neckerchiefs, pins, bags, sleeping bags, ...) as well as the typical stonemasons' equipment (boots, gloves, hats, bottle,...). All promotional gadgets should follow the principle of sustainability, meaning that they should be made locally with as much as possible ecological material yet following the general visual identity of the route. Recycled stone could be used for the production of promotional material of useful small-size (not too heavy) souvenirs (necklaces, etc...).

\section{Interpretive infrastructure}

Should also follow the jointly predefined visual identity of the route but also respect the local specificities. The bottom-line idea of interpretive infrastructure should follow the general aims: a) respect multi-faceted significance of the sites, b) respect for the natural environment and geographical setting, c) sustainability and zero-waste economy.

The (im-)movable objects for the interpretation infrastructure of the cultural routes and selected show-case sites and quarries will be based on the "zero waste" concept. ${ }^{5}$ It aims at using those parts of stone as the building material that usually go wasted in the production process. Such material would be reused through innovative design solutions for new design products in this case interpretation infrastructure, namely interpretive panel-like or similar supports. With the help of creative industries, a new, useful dimension would be given to the waste stone, moreover, this principle will also call the attention to the issues of stone extraction and design. Likewise, recycled stone could be used for the production of promotional material or for useful souvenirs (see above).

\section{Workshops on sustainable use of natural stone}

As a part of educational and awareness raising activities, a set of workshops could be organised in the different sites of project area with local partners and local craftsmen, so to produce the interpretation infrastructure. At these events professionals, namely craftsmen from other related sites of the route would be invited. Workshops would address both professional skilled-staff but also the general public and thus be a part of the wider tourist-offer of the along the route. As a hands-on experience for visitors and tourists, the proposal complies with the topical trends of developing "creative tourism".

\section{Re-use of sites}

A particular activity in this ECR proposal encompasses the promotion of abandoned quarry sites. Selected active quarries would be an integral part of the local itineraries, show-casing the contemporary stone extraction in quarries. Some of them have already included a presen-

\footnotetext{
5 This section of the pre-study was prepared on the idea of Tjaša Kranjec from the vocational school center of Sežana (Visokošolsko središče Sežana) who was supposed to be also a partner in the RoofOfRock follow-up project » House of Rock «.

6 Seewww.creativetourismnetwork.org
} 
tation structure, showing quarrying and related techniques as technical heritage. There are, however, several closed and abandoned quarries which are still clearly visible in the landscape and have a great potential for re-use. Their potential consists of their natural setting, the good road-connection and the (most probable) existence of basic infrastructure (electricity \& water-supply, minor built structure). Considering these characteristics, some could be occasionally re-used as performance areas for concerts, theatre performance, festivals etc. A good example is the site of the former Repnič-Rupinpiccolo quarry, in the area of the village Briščiki (Borgo Grotta), in the area of Trieste, where the quarry effects as an amazing natural amphitheatre (FIGURE 4). Activities in these re-used sites would be a part of the Interpretation plan and Management plan of the route. Here as well, each re-used site would promote the other similar sites on the route.

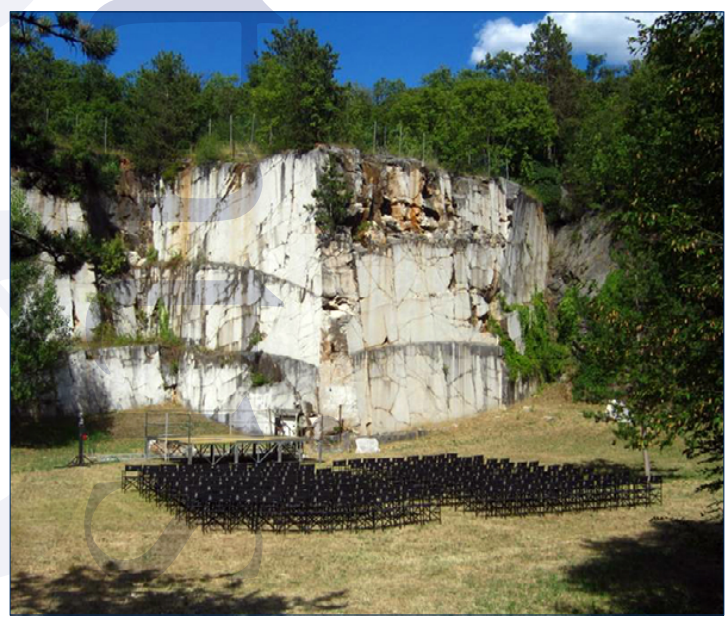

Fig.4: Quarry of Repnič-Rupinpiccolo (Briščiki/Borgo Grotta near Trieste), before a performance.

Photo: Neža Čebron Lipovec, 2013

\section{Reference best practices}

In any case, this pre-study could only hardly be outlined without the experiences, gained through previously well-accomplished projects on the interdisciplinary field of cultural heritage, implemented by University of Primorska. Several (national, bilateral, but mainly international) projects have set as one of the objectives the improved heritage interpretation, revitalisation of cultural heritage, promotion of heritage, ... etc. in order to increase the access to the heritage, to raise the awareness of the meaning of the cultural heritage as our common wealth, as our inheritance from previous generations and our legacy for those to come. Therefore the enrichment of tourism offer and consequently the increased number of visitors has been one of the regular indicators.

In this chapter we will point out two projects led by University of Primorska that have had as one of the results the setting up of the cultural heritage-oriented itineraries, which have been adjusted to various groups of visitors and are therefore understood as the examples of the good practice in the field. The long-term plan is (in accordance with priority areas of EU - promotion of culture as a vital element of the Union's international dimension) to maximise the potential of cultural heritage and to highlight its international and timeless meaning as the common wealth.

\section{AS - Archaeology for all. Revival of the} Archaeological park Simonov zaliv

During the project $A S$ - Archaeology for all. Revival of the Archaeological park Simonov zaliv (EEA Grants, EGP Grants 20og-2014) three different archeo tours, meant for solo visitors, as well as for guided groups, were developed - two land routes (for hikers and cyclists) and one maritime. The land routes are based on the already developed tourist hiking and cycling maps of the surroundings of Izola, issued by Touristic Informative Centre of Izola that were modified and adjusted to the needs of the archeo tour. Both tours are available in long and short versions with the possible shortcuts.

Each monument, site or highlighted points of interest (esp. on maritime route) on the route has its own unit in the free version of the mobile application for the smart phones. The mobile application raises awareness when the sightseer is in the direct vicinity of the attraction and one 
can peruse a general overview on the screen or can, if it has raised an interest, make profit of the more detailed description and more information with only one click. Some objects are also linked with other tourism offers nearby - like village's inns with traditional cuisine or breathtaking viewpoints.

Despite the title none of the routes is strictly only archaeological, as there is also some stress on the cultural, as well as natural heritage sights (like the pilgrimage church of St. Mary in Strunjan, traditional village Cetore or Natural Park Strunjan with the adjoining salt pans).

\section{Living Landscape}

The extremely rich intangible heritage of karstic area in Slovenia and Italy was (as in general overview counts for the intangible heritage as a whole) neglected until the last decades, as even UNESCO only in 2003 passed the Convention for the Safeguarding of the Intangible Cultural Heritage.

Within the bilateral, Italian-Slovenian, project Living Landscape (SLO IT PP3 2013-2015) under the leadership of University of Primorska and in collaboration not only with the project partners and experts on the field, but what is of the special importance for the integration in the local environment, also with the students and local community, the mythological-folklore park Rodik has been designed. Although the park has (due to the lack of money) not been set yet, all the necessary steps towards the final implementation have already been made. The comprehensive elaborate includes the locations and the interpretation of the single sites with the short description. Additionally, the official permission for the creation of the park (taking into account the guidelines set in the elaborate) from the Institute for the Protection of Cultural Heritage of Slovenia has been already gained. Each mapped location would be equipped with the explanation that would be (under the consideration of the natural heritage sites protection) ecological-

Convention for the Safeguarding of the Intangible Cultural Heritage, UNESCO 2003, www.unesco.org/culture/ich/en/convention. ly and non-invasively put into the marking posts made of stone. The design for the posts was created in collaboration with the vocational school in Sežana, the only educational entity with the course of the stone processing in Slovenia.

\section{Camino de Santiago or The Way of St. James}

Needless to say, the most highly developed and numerously visited European routes ever since the Early Medieval Ages have been without a single doubt pilgrimage routes. The most famous route, Camino de Santiago or The Way of St. James, is each year undertaken by more than I00.000 people from the whole Europe, who have taken it not only to see in vivo the shrine of apostle St. James the Great in the Cathedral of Santiago de Compostela in Galicia in Spain, but also to spiritually clean theirselves or to visit and stop by numerous churches and other sacral buildings built through centuries on the road.

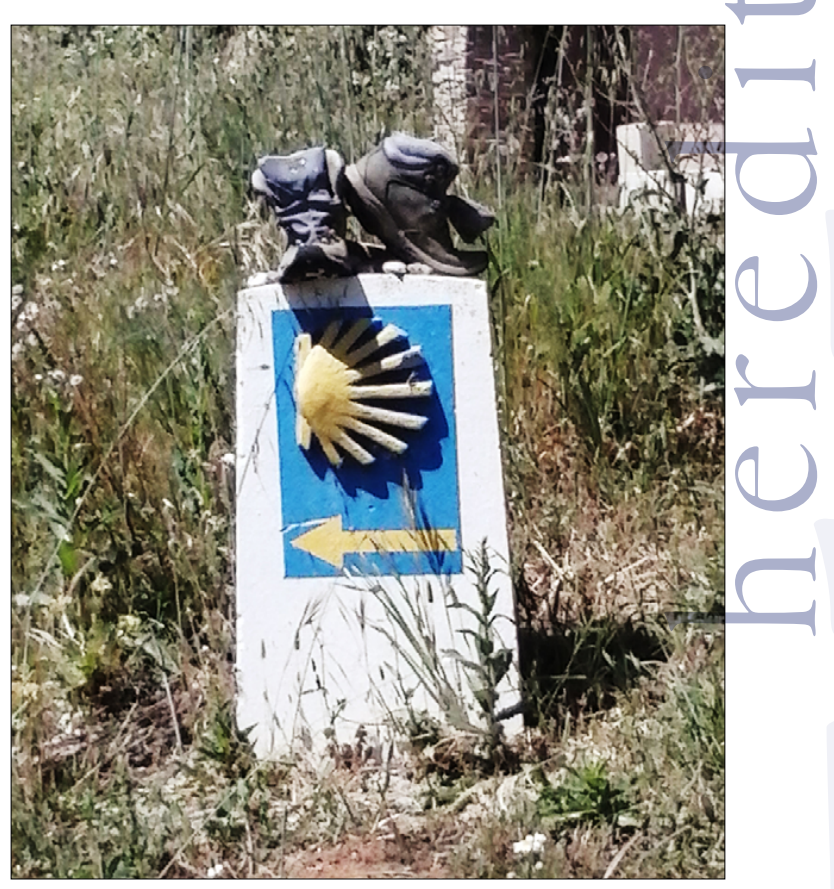

Fig.s: A typical signpost, with Jacobs' scalop as symbol, along the pilgrims way. Photo: Janja Rižnar zors.

Through constant and ceaseless pilgrimage from all over Europe a very ramified system of the paths that lead to the same target has 
been established - the most besieged has been The French Way with many medieval churches, cathedrals and abbeys that have served also as the rallying points for the pilgrims. The paths are marked by St. James' symbol, the scallop shell, that at every step welcomes visitors, and by several marking posts. As a tourist offer also ,pilgrim's passports" are provided, in which the modern pilgrim can collect the stamps, obtained in refugio (dormitories) or churches in the towns on the road. The owner of the passport can also profit from inexpensive - or even free - accommodation, provided only for the pilgrims. (FIGURE s)

In any case, the well-visited pilgrimage routes are a the best and the most famous show case that clearly demonstrates not only the transregional, but also the underlined transnational characteristics of the beaten ramified paths that have been in use for more than millennium without a major caesura.

\section{Conclusion}

The proposed cultural route of stonemasons and stones in the Adriatic is set as a desirable complement to the already existing cultural routes recognized by the Council of Europe, as it fulfils all the major requirements for the cultural route (as proposed by the Council of Europe) - it is multidisciplinary based, contributes to the interpretation and promotion of the common $\mathrm{Eu}-$ ropean heritage, one of its objective is to educate the younger generation to respect the values of our common heritage, its functioning and maintenance are linked to the tourism and to the enhancement of the tourism offer.

Moreover, through previously completed projects on the field of cultural heritage and especially through already established system of the European cultural routes has to a great degree stood out not only the transregional, but also the transnational character of the cultural heritage, as the comparable heritage monuments are dispersed disregarding the borders, but with the look on the natural assets, commissions, historical background, etc.
The proposed Stonemasons' route will set out whether the stonemasons' paths strictly follow the stone trade path or whether there are some - smaller or larger - deviations, which have in all probability occurred because of the noble and well-off commissioners - not only the clergy but also the wealthy trading cities or nobility. Together with all the accompanying activities as well as the promotional material, gadgets and professional booklets, as also with the educational material for children and the recognisable logo, the route will encourage the random sightseers as well as the organised groups to deepen their knowledge on something as usual and as taken for granted as is stone as the building material. They will be encouraged to dig deeper and to follow the ramified curved paths of the stonemasons, as well as to the common types of the architectural heritage or the architectural decoration.

\section{Summary}

A pre-study that is generally based on the results of the well-accomplished international multidisciplinary project RoofOfRock, proposes a follow up of the project activities the concept of the cultural route that would draw attention to the ramified paths of the itinerant stonemasons and their workshops in the Adriatic. The elaborate is made in line with the concept of the already existing cultural routes, as was established by the Council of Europe.

The proposed cultural route would highlight the ramified system not only of the paths that were taken by the stonemasons in order to get the commission, as well as the stone trade. Along the route show-cases, buildings made of stone that stand out due to their artistic, architectural and cultural value are chosen and put on the map that is complemented by the booklet. However, the elaborate considers also intangible heritage (stone crafts) and also the natural assets that enabled the stone extraction and the stone trade. The concept proposes some ideas for the revitalisation - re-use of the sites like abandoned quarries.

The route and its branches would be accompanied by the recognisable logo, map, booklet, interpretive programme, didactic tools and by other promotional mate- 
rial for different age groups (adults, children) in order to encourage the visitors to broaden their horizons about the stone, stone trade, stonemasons, etc. Its final objective is to promote the cultural, as well as natural heritage as our common European wealth that has to be maintained and respected as the route strictly points out the transnational and transregional character.

\section{Povzetek}

Študija v osnovi temelji na rezultatih zaključenega mednarodnega interdisciplinarnega projekta RoofOfRock in kot nadaljevanje projektnih aktivnosti predlaga zasnovo kulturne poti, ki bi opozorila na razvejane poti potujočih kamnosekov in njihovih delavnic $\mathrm{v}$ jadranskem prostoru. Elaborat je pripravljen skladno s konceptom že zasnovanih kulturnih poti, kakršne so nastale pod okriljem Sveta Evrope.

Predlagana kulturna pot bo osvetlila razvejan sistem poti, in to ne samo tistih, ki so jih ubrali kamnoseki, da bi dobili naročilo, temveč tudi poti trgovine s kamnom. $\mathrm{Na}$ poti bodo predstavljeni izbrani „Vzorčni primeri“ (show-cases), stavbe, narejene iz kamna, ki izstopajo po svoj umetniški, arhitekturni in kulturni vrednosti. Ti primeri bodo označen na zemljevidu, ki bo dopolnjen z brošuro. Elaborat obravnava tudi nesnovno dediščino (obrti, povezane s kamnom) in naravne danosti, ki so omogočile izkoriščanje kamna in trgovino s kamnom. Koncept predlaga tudi nekaj idej za revitalizacijo - ponovno uporabo mest, kakor so na primer zapuščeni kamnolomi.

Pot in vse njene veje bodo opremljene s prepoznavnim logotipom, zemljevidom, brošuro, interpretativnim programom, didaktičnimi orodji in ostalim promocijskim materialom, namenjenih za različne starostne skupine (odrasli, otroci), vzpostavljenimi z namenom, da bi si obiskovalci razširili svoja obzorja o kamnu, trgovini s kamnom, kamnosekih, etc. Končni cilj je promocija tako kulturne kot tudi naravne dediščine kot našega skupnega evropskega bogastva, ki ga je potrebno vzdrževati in spoštovati, saj pot izrazito poudari mednacionalni in medregionalni značaj.

\section{Bibliography and Sources}

Capp, Sorina. The European Institute for Cultural Routes. www.arcchip.cu/wo2/wo2_ capp.pdf 2006.
Grobovšek, Jovo, ed. Doktrina 2, Mednarodne listine in dokumenti ICOMOS. Ljubljana: ICOMOS Slovenija, 2014.

Lopez, Lucrezia, and Rubén Camilo Lois Xosé Santos Solla. „Promoting or being Promoted? The Case of the Way of St. James." In The European pilgrimage routes for promoting sustainable and quality tourism in rural areas, ed. Gianluca Bambi, Matteo Barbari, 817-833. Firenze: Firenze University Press, 2015 .

Official Journal of the European Union, 29. II. 2007.

Pirkovič, Jelka. Arheološko konservatorstvo in varstvo nepremične kulturne dedišcine. Ljubljana: Filozofska fakulteta, 20 I2.

Premrl, Božidar. Podpisano srcem: kraška kamnoseška rodovina Guštinov skozi stoletja: Repentabor - Sežana-Opčine - Griže na Vrheh. Trst: Založništvo tržaškega tiska, 2014.

Premrl, Božidar. „Stavbarska delavnica družine Rojina v Brezovici v Brkinih v 17. stoletju in na začetku I8. stoletja." In Barok na Goriškem - Il barocco nel Goriziano, ed. Ferdinand Šerbelj, 25I-270. Nova Gorica: Goriški muzej, 2006

Van Mesch, Peter, Mejier - van Mensch, Leontine, Rihter, Andreja. New Trends in Museology. Celje: Museum of Recent history, 20II.

www.creativetourismnetwork.org

www.culture-routes.net

www.interpret-europe.net

www.interpretingheritage.eu/en.

www.primorski.it

www.roofofrock.eu

www.unesco.org/culture/ich/en/convention

\section{1

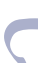
e

-




\title{
Rimski vojaki na območju Slovenije od ustanovitve Akvileje do vdora Markomanov in Kvadov
}

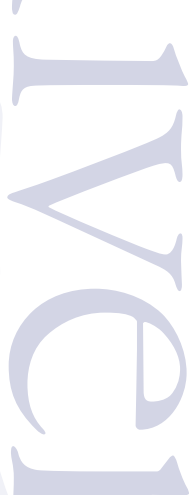

\author{
Jan Cotič
}

The presented paper is based on already published inscriptions mentioning roman soldiers, their functions and units in which they served. This type of research problem was chosen during the review of current state of research and literature about the Roman army in today's Slovenia. In addition to other (non-military) inscriptions, the majority of them are stored in lapidaries of the National museum of Slovenia in Ljubljana and in regional museums of Celje and Ptuj-Ormož. The remaining part of the inscriptions is distributed among the Dolenjska museum in Novo mesto, Bela krajina museum in Metli$\mathrm{ka}$ and in the lapidary of the Carinthian regional museum in Slovenj Gradec. Some inscriptions are also inbuilt in churches, castles, mills and houses.

Inscriptions with its content supplement the archeological findings of the discussed period and contribute to a better and more comprehensive picture of roman military presence and functioning in the region of today's Slovenia. Roman military inscriptions are collected in a catalog and accurately analyzed according to military functions and units mentioned on inscriptions. Its aim is to explain the presence and the structure of the roman army in present-day Slovenia between the foundation of Aquileia and the invasion of the Marcomanni and the Quadi. All Inscriptions after this period are therefore listed in tabular form only.

Key words: Roman period, epigraphic, roman provinces, roman army, military units, military functions

pregledom stanja raziskav in literarure je moč ugotoviti, da pomemben vir za sestavo celostne slike o rimski vojaški aktivnosti na slovenskem prostoru predstavljajo viri antičnih avtorjev, ${ }^{1}$ ki so s konkretnimi materialnimi dokazi podprti zgolj na posameznih lokacijah (npr. Grad pri Šmihelu, Dolge njive pri Vrhniki, Grad pri Reki, reka Ljubljanica, Ločica pri Polzeli itd.). Slovenski prostor je v času rim-

I Titus Livius - Aburbe Conditaliber XLI (Marjeta Šašel Kos, Situla Volume 43: Appian and Illyricum (Ljubljana: Narodni muzej Slovenije, 2005), 32 I-322), Appianos - Romaiká (Šašel Kos, Rimsko osvajan je zahodnega Balkana (Ljubljana: Zveza zgodovinskih društev Slovenije, 2010), 176), Hostius - Bellum Histricum (Šašel Kos, Appian and Illyricum, 323), Tacitus - Annales, Ab excessu divi Augusti, Cassius DioRhomaike historiae skih osvajalnih pohodov veljal za prostor $\mathrm{z}$ izrazito prehodno lego in stičišče med Italijo in jugovzhodno Evropo. Zato je bila nastanitev legij ali manjših vojaških oddelkov v veliki meri povezana z gradnjo cestnega omrežja, obrambo pred morebitnimi vdori obmejnih sovražnih ljudstev in bila kasneje pogojena $\mathrm{z}$ nadzorom rimskih trgovskih in transportnih poti, ki so vodile $\mathrm{v}$ matično Italijo.

Analiza obravnavanih vojaških napisov bo pokazala ali je bila prisotnost vojaških oddelkov na slovenskem prostoru pogojena $\mathrm{z}$ osvajanjem jugovzhodnoalpskega in zahodnobalkanskega prostora ter kako ohranjeni napisi odražajo razmerje v številu vojakov in vojaških oficirjev. 
Rimski vojaški napisi najdeni v Sloveniji so bili kot tema raziskave že podrobneje obravnavani predvsem za območje Emone in Celeje. Kot del raziskave povezane $\mathrm{z}$ nastankom Emone so nekatere vojaške napise obravnavali Balduin Saria, ${ }^{2}$ Jaroslav Šašel ${ }^{3}$ in Marjeta Šašel Kos, ${ }^{4}$ Julijana Visočnik pa je poglobljeno raziskavo vojaških napisov opravila za območje Celeje in njenega agra, zato so njene ugotovitve samo povzete. Vojaški napisi iz Emone, Petovione, Nevioduna in Pretorija Latobikov so bili kot celota zabeleženi in opisani $\mathrm{v}$ strokovnih in znanstvenih objavah, npr. vodnikih po lapidarijih ${ }^{6}$ pristojnih muzejev, katalogih razstav ter $\mathrm{v}$ znanstvenih objavah.?

Rezultati raziskovanja so predstavljeni kvantitativno v obliki tabel ter kvalitativno. Slovenski prostor je bil v smislu vojaškega delovanja v veliki meri prehodnega značaja, zato je moč sklepati, da bodo opazna minimalna odstopanja $\mathrm{v}$ razmerju med napisi vojakov in vojaških oficirjev. Preučeni rezultati so dali drugačen pogled na obravnavano temo, saj je raziskava pokazala, da je razmerje predstavnikov vojske in oficirjev odvisno od kraja (in njegovega statusa ter časa nastanka), kjer so bili nastanjeni.

\section{Katalog vojaških napisov}

Iz Emone in njene okolice je poznanih dvanajst vojaških napisov: deset nagrobnih napisov (št. I, 2, 5, 6, 7, 8, 9, IO, II in I2/I3) in dva votivna oltarja (št. 3 in 4$)$. Na štirih spomenikih so izpričani štirje veterani, pri tem sta $v$ treh primerih eno-

2 Balduin Saria, "Vojaški nagrobni napis iz Emone," Kronikaslovenskih mest 3, no. I (1937): 46-48.

3 Jaroslav Šašel, Situla, Volume 3 o - Opera Selecta: Pro Legato (Ljubljana: Narodni muzej, 1992), 305-315.

$4 \quad$ Marjeta Šašel Kos, "Je bila Emona nekdanji tabor 15. legije in veteranska kolonija?" Zgodovinski časopis 52, no. 3 (112) (1998): 317-329, Marjeta Šašel Kos, "The isth Legion at Emona - Some thoughts," Zeitschrift für Papyrologie und Epigrafik I09 (1995): 227-244.

5 Julijana Visočnik, "Vojaški napisi iz Celeje in njene okolice," Arheoloskivestnik 59 (2008): 325-357.

6 BlagojJevremov, Vodnik po lapidarju I. del (Ptuj: Pokrajinski muzej, 1988), Marjeta Šašel Kos, Lapidarij Narodnega muzeja Sloveni je-Rimskispomeniki-Vodnik (Ljubljana: Narodni muzej Slovenije, 2004).

7 Lovenjak, Situla, Volume 37: Neviodunum - Inscriptiones Latinae Slovenia (ILSI) I, Šašel Kos, "Je bila Emona nekdanji tabor I5. legije in veteranska kolonija?", 317-329. ti navedeni (št. 9, II in I2/13) in v enem ne (št. IO). Starost je navedena na nagrobniku veterana Tita Varia (št. 9), ki je ob svoji smrti štel 60 let.

Tabela I: Število obravnavanih rimskih vojaških napisov najdenih v Sloveniji

\begin{tabular}{lc} 
Emona & 13 \\
\hline Petovio & 20 \\
\hline Neviodunum & 16 \\
\hline Practorium Latobicorum & 18 \\
Celeia & 52 \\
$\begin{array}{l}\text { predstavniki vojske na posamičnih lokacijah po Slo- } \\
\text { veniji }\end{array}$ & 1
\end{tabular}

SKUPAJ 120

Z oznako, ki se nanaša na navadnega vojaka (miles), so izpričani trije vojaki (št. 5, 6 in 7). Izraz miles se pojavi tudi na nagrobnikih pretorijanca Pudensa (št. 2) in Lucija Elija Nigrina (št. 8), ki je kot vojak marinec (militi classis) služil v Panonskem ladjevju. Kot edini omenjeni pretorijanec je Pudens vojaško službo opravljal v Drugi pretorijanski kohorti (Cohors II Praetoriae), a je očitno ni dokončal, saj je na nagrobniku navedeno, da je odslužil 7 let in umrl pri 25. letih.

$\mathrm{Na}$ devetih napisih je navedena pripadnost vojakov posameznim legijam. Petnajsta Apolonova legija je navedena na napisih št. 4, 5, 9 in I2, trinajsta Dvojna legija pa na napisih št. 3, 6, 7 , in II. $\mathrm{Na}$ nagrobnem napisu veterana Lukija Oklacija (št. 12) je omenjen tudi veteran Tit Kalvencij, ki je vojaško službo opravljal v osmi Avgustovi legiji (št. 13). Slednja je bolje dokumentirana na območju današnjega Ptuja. Imena legij so na napisih št. 4, 9, I2, I3 navedena samo s številko, kar dokazuje, da so nekatere legije bile prisotne na tem območju že pred uvedbo Avgustovih vojaških reform.

Med vojaškimi napisi iz Emone je po opravljanju vojaške službe najbolj izpoveden nagrobnik Tita Junija Montana (št. 1), ki navaja, da je svojo bogato vojaško kariero šestkrat opravljal kot vojaški tribun, šestkrat je bil prefekt konjenice,

Kate Gilliver, "The Augustan Reform and Structure of the Imperial Army," in A Companion to the Roman Army, ur. Paul Erdkamp (Chichester: Willy-Blackwell, 2007), 185, 188. 
Tabela 2: Predstavniki vojaških oficirjev v Emoni

\begin{tabular}{|c|c|c|c|c|c|c|c|}
\hline$\check{S}_{t}$ & Ime oficirja & $\begin{array}{c}\text { Funkcija, } \\
\text { vojaška enota }\end{array}$ & Starost & Datacija & Vrsta napisa & Najdišče & Objava \\
\hline I. & $\begin{array}{l}\text { Titus Iunius } \\
\text { Montanus }\end{array}$ & $\begin{array}{l}\text { tribunus mili- } \\
\text { tium, praefec- } \\
\text { tus equitum, } \\
\text { praefectus fab- } \\
\text { rum, pro le- }\end{array}$ & / & $\begin{array}{l}\text { avgustejsko ob- } \\
\text { dobje }\end{array}$ & nagrobni napis & Ljubljana & $\begin{array}{l}\check{S}_{\text {ašel Kos, }} \\
2004,85 \text {, št. } 36\end{array}$ \\
\hline
\end{tabular}

Tabela 3: Predstavniki vojske v Emoni

\begin{tabular}{|c|c|c|c|c|c|c|c|}
\hline$\check{S}_{\text {t. }}$ & Ime vojaka & $\begin{array}{c}\text { Funkcija, } \\
\text { vojaška enota }\end{array}$ & Starost & Datacija & Vrsta napisa & Najdišče & Objava \\
\hline \multirow{3}{*}{2.} & & Praetoriani & & & & & \\
\hline & Pudens & $\begin{array}{l}\text { miles cohortis } \\
\text { II praetoriaie }\end{array}$ & 25 & verjetno i.st. & nagrobni napis & Ljubljana & $\begin{array}{l}\text { Šašel Kos, } \\
2004,85 \text {, śt. } 37\end{array}$ \\
\hline & & Signiferi & & & & & \\
\hline 3. & $\begin{array}{l}\text {... Valerius } A \\
\text { milianus }\end{array}$ & $\begin{array}{l}\text { signifer legi- } \\
\text { onis XIII Ge- } \\
\text { minae }\end{array}$ & / & verjetno 3. st. & $\begin{array}{l}\text { votivni napis } \\
\text { (posvetilo Jupi- } \\
\text { tru Odvračal- } \\
\text { cu zla ali Doli- } \\
\text { henskemu) }\end{array}$ & Ljubljana & $\begin{array}{l}\text { Šašel Kos, } \\
2004,82 \text {, št. } 17\end{array}$ \\
\hline & & Frumentarii & & & & & \\
\hline \multirow[t]{2}{*}{4.} & Vibius & $\begin{array}{l}\text { frumentarius } \\
\text { legionis XV }\end{array}$ & / & $\begin{array}{l}\text { prva polovi- } \\
\text { ca i. st. }\end{array}$ & $\begin{array}{l}\text { votivni napis } \\
\text { (oltar posvečen } \\
\text { Cereri) }\end{array}$ & Ljubljana & $\begin{array}{l}\text { Šašel Kos, } \\
2004,80 \text {, št. } 8\end{array}$ \\
\hline & 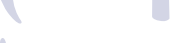 & Milites & & & & & \\
\hline 5. & $\begin{array}{l}\text { Caius Clodius } \\
\text { Secundus }\end{array}$ & $\begin{array}{l}\text { miles legio- } \\
\text { nis XV Apoli- } \\
\text { naris }\end{array}$ & / & $\begin{array}{l}\text { prva polovi- } \\
\text { ca i. st. }\end{array}$ & nagrobni napis & Ljubljana & $\begin{array}{l}\text { Šašel Kos, } \\
2004,86, \text { śt. } 38\end{array}$ \\
\hline 6. & $\begin{array}{l}\text { Marcus Aure- } \\
\text { lius Crispini- } \\
\text { anus }\end{array}$ & $\begin{array}{l}\text { miles legionis } \\
\text { XIII Geminae }\end{array}$ & / & $253-268$ & nagrobni napis & Ljubljana & $\begin{array}{l}\text { Šašel Kos, } \\
2004,87, \text { št. 4I }\end{array}$ \\
\hline 7. & / & $\begin{array}{l}\text { miles legionis } \\
\text { XIII Geminae }\end{array}$ & / & 3. st. & nagrobni napis & Ljubljana & $\begin{array}{l}\text { Šašel Kos, } \\
2004,87, \text { št. } 42\end{array}$ \\
\hline \multirow[t]{2}{*}{8.} & $\begin{array}{l}\text { Lucius Aelius } \\
\text { Nigrinus }\end{array}$ & $\begin{array}{l}\text { militi classis } \\
\text { Pannonicae }\end{array}$ & / & konec 2. ali 3. st. & $\begin{array}{l}\text { nagrobni napis } \\
\text { (odlomek nag- } \\
\text { robnika) }\end{array}$ & Ljubljana & $\begin{array}{l}\text { Šašel Kos, } \\
2004,87 \text {, št. } 44\end{array}$ \\
\hline & & Veterani & & & & & \\
\hline 9. & Titus Varius & $\begin{array}{l}\text { veteranus legi- } \\
\text { onis XV }\end{array}$ & 60 & $\begin{array}{l}\text { prva polovi- } \\
\text { ca i. st. }\end{array}$ & nagrobni napis & Ljubljana & $\begin{array}{l}\text { Šašel Kos, } \\
2004,86, \text { št. } 39\end{array}$ \\
\hline IO. & $\begin{array}{l}\text { Caius } \\
\text { Vettennius }\end{array}$ & veteranus & / & $\begin{array}{l}\text { verjetno prva } \\
\text { polovica I. st. }\end{array}$ & nagrobni napis & Ljubljana & $\begin{array}{l}\text { Šašel Kos, } \\
2004,87 \text {, št. } 40 .\end{array}$ \\
\hline
\end{tabular}




\begin{tabular}{|c|c|c|c|c|c|c|c|}
\hline Št. & Ime vojaka & $\begin{array}{c}\text { Funkcija, } \\
\text { vojaška enota }\end{array}$ & Starost & Datacija & Vrsta napisa & Najdišče & Objava \\
\hline II. & $\begin{array}{l}\text { Aurelius Io- } \\
\text { vinus }\end{array}$ & $\begin{array}{l}\text { veteranus legi- } \\
\text { onis XIII Ge- } \\
\text { minae }\end{array}$ & / & 3. st. & nagrobni napis & Ljubljana & $\begin{array}{l}\text { Šašel Kos, } \\
2004,87, \text { št. } 43\end{array}$ \\
\hline $\mathrm{I} 2$. & $\begin{array}{l}\text { Lucius Ocla- } \\
\text { tius }\end{array}$ & $\begin{array}{l}\text { veteranus legi- } \\
\text { onis XV }\end{array}$ & / & \multirow{2}{*}{$\begin{array}{l}\text { prva polovi- } \\
\text { ca I. st. }\end{array}$} & \multirow{2}{*}{ nagrobni napis } & \multirow{2}{*}{ Ljubljana } & \multirow{2}{*}{$\begin{array}{l}\text { Šašel Kos, } 1998, \\
332, \text { št. } 3\end{array}$} \\
\hline 13. & $\begin{array}{l}\text { Titus Calven- } \\
\text { tinus }\end{array}$ & $\begin{array}{l}\text { veteranus legi- } \\
\text { onis VIII }\end{array}$ & / & & & & \\
\hline
\end{tabular}

Tabela 4: Predstavniki vojske v Petovioni

\begin{tabular}{|c|c|c|c|c|c|c|c|}
\hline$\check{S}_{\mathrm{t} .}$ & Ime vojaka & $\begin{array}{c}\text { Funkcija, } \\
\text { vojaška enota }\end{array}$ & Starost & Datacija & Vrsta napisa & Najdišče & Objava \\
\hline & & Beneficiarii & & & & & \\
\hline \multirow[t]{2}{*}{14.} & $\begin{array}{l}\text { Caius Corne- } \\
\text { lius Proculus }\end{array}$ & $\begin{array}{l}\text { beneficiarius } \\
\text { tribunus, miles } \\
\text { legionis XIII } \\
\text { Geminae }\end{array}$ & / & sredina I. st. & nagrobni napis & $\begin{array}{l}\text { Spodnja Haj- } \\
\text { dina }\end{array}$ & $\begin{array}{l}\text { Jevremov, } 1988 \text {, } \\
46, \text { št. I } 4\end{array}$ \\
\hline & & Centuriones & & & & & \\
\hline 15. & $\begin{array}{l}\text { Marcus Petro- } \\
\text { nius Classicus }\end{array}$ & $\begin{array}{l}\text { centurio legi- } \\
\text { onis VIII Au- } \\
\text { gusta }\end{array}$ & / & $\begin{array}{l}\text { prva polovi- } \\
\text { ca I. st. }\end{array}$ & nagrobni napis & $\begin{array}{l}\text { Ptuj (videmska } \\
\text { cerkev) }\end{array}$ & $\begin{array}{l}\text { Jevremov, } 1988 \text {, } \\
39 \text {, št. } 6\end{array}$ \\
\hline 16. & $\begin{array}{l}\text { Marcus Clau- } \\
\text { dius Avitus }\end{array}$ & $\begin{array}{l}\text { centurio legio- } \\
\text { nis X Geminae } \\
\text { pia fidelis }\end{array}$ & / & 2. st. & $\begin{array}{l}\text { votivni napis } \\
\text { (oltar posvečen } \\
\text { Jupitru) }\end{array}$ & Vičava & $\begin{array}{l}\text { Jevremov, } 1988 \text {, } \\
99 \text {, št. } 105\end{array}$ \\
\hline \multirow[t]{2}{*}{17.} & Martial & $\begin{array}{l}\text { centurio legi- } \\
\text { onis XIII Ge- } \\
\text { minae }\end{array}$ & / & 3. st. & $\begin{array}{l}\text { votivni napis } \\
\text { (oltar posvečen } \\
\text { Diani) }\end{array}$ & Ptuj (Titov trg) & $\begin{array}{l}\text { Jevremov, } 1988, \\
\text { I09, št. } 120\end{array}$ \\
\hline & & Praefecti & & & & & \\
\hline 18. & $\begin{array}{l}\text { Aelius Ma- } \\
\text { rinus }\end{array}$ & $\begin{array}{l}\text { praefectus co- } \\
\text { hortis II Hispa- } \\
\text { norum }\end{array}$ & / & \multirow{2}{*}{$\begin{array}{l}\text { druga polovi- } \\
\text { ca 2. in začetek } \\
\text { 3. st. }\end{array}$} & \multirow{2}{*}{ nagrobni napis } & \multirow{2}{*}{ Vičava } & \multirow{2}{*}{$\begin{array}{l}\text { Jevremov, } 1988 \text {, } \\
\text { II5, št. I32 }\end{array}$} \\
\hline \multirow[t]{2}{*}{19.} & $\begin{array}{l}\text { Publius Aelius } \\
\text { Marcianus }\end{array}$ & $\begin{array}{l}\text { preaefectus co- } \\
\text { hortis I Ger- } \\
\text { manorum }\end{array}$ & / & & & & \\
\hline & & Optii & & & & & \\
\hline \multirow[t]{2}{*}{20.} & $\begin{array}{l}\text { Lucius Faninus } \\
\text { Quadratus }\end{array}$ & $\begin{array}{l}\text { optio legionis } \\
\text { I Adiutricis pia } \\
\text { fidelis }\end{array}$ & / & 2. st. & nagrobni napis & $\begin{array}{l}\text { Ptuj (minorit- } \\
\text { ska cerkev) }\end{array}$ & $\begin{array}{l}\text { Jevremov, } 1988 \text {, } \\
37 \text { št. } 3\end{array}$ \\
\hline & & Primi hastati & & & & & \\
\hline 21. & Saturninus & $\begin{array}{l}\text { primus hasta- } \\
\text { tus legionis } \\
\text { VIII Augusta }\end{array}$ & 70 & $\begin{array}{l}\text { prva polovi- } \\
\text { ca I. st. }\end{array}$ & nagrobni napis & $\begin{array}{l}\text { Ptuj (videmska } \\
\text { cerkev) }\end{array}$ & $\begin{array}{l}\text { Jevremov, 1988, } \\
40, \text { št. } 7\end{array}$ \\
\hline
\end{tabular}




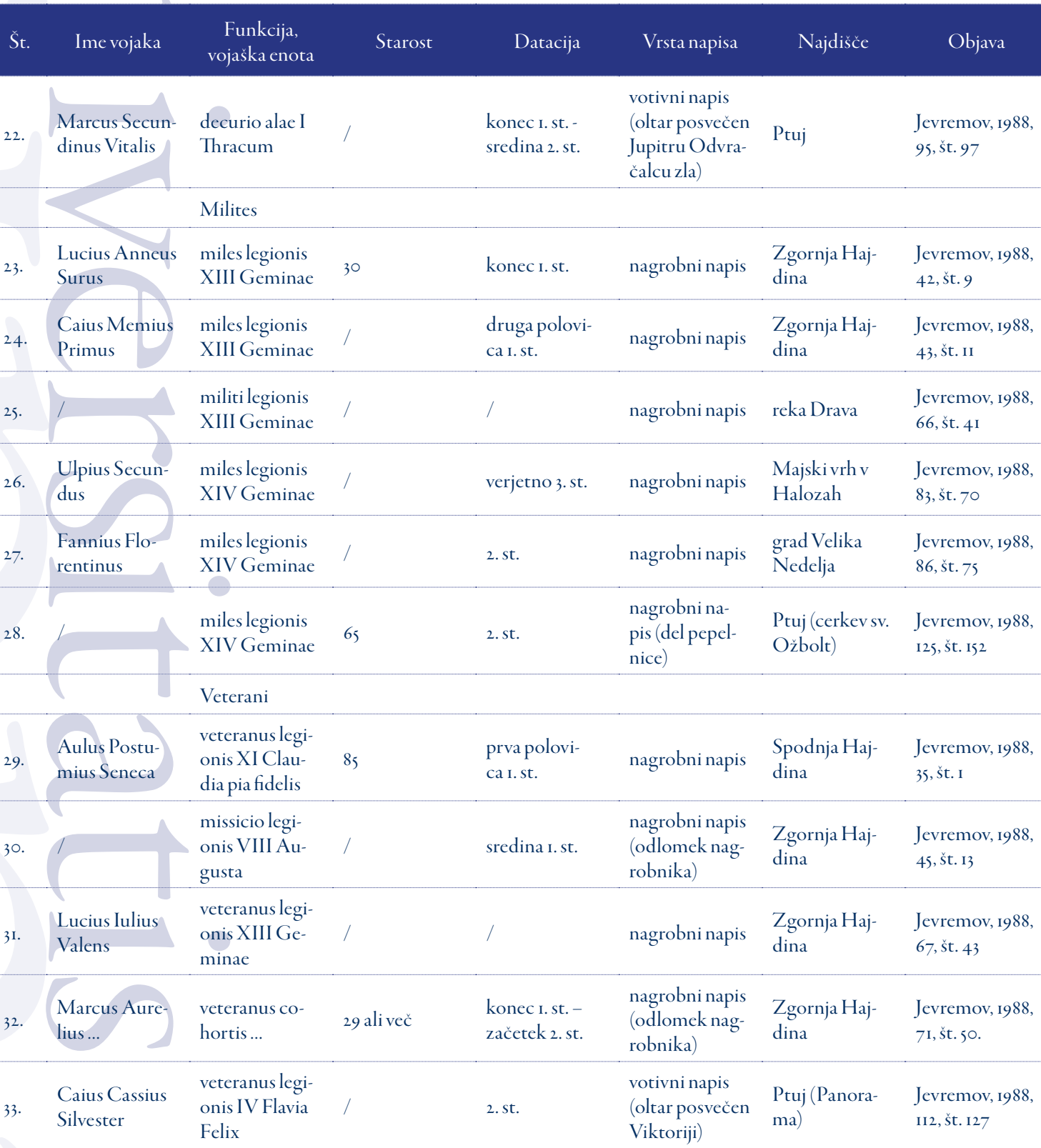

dvakrat načelnik inženirjev in dvakrat oficir viteškega stanu. ${ }^{9}$ Funkcija pro legato je nekoč bila interpretirana kot namestnik legijskega poveljnika, tako piše tudi Balduin Saria, ki je domneval, da je Montan poveljeval petnajsti Apolonovi legiji. ${ }^{10}$ Njegovo tezo je prvi ovrgel Jaroslav

9 Šašel Kos, Lapidarij Narodnega muzeja Slovenije-RimskispomenikiVodnik, 85, no. 36.

Io Saria, "Vojaški nagrobni napis iz Emone," 46.
Šašel, ki je natančno analiziral to funkcijo in zaključil, da ta naziv ni pomenil legijskega poveljnika, temveč oficirja viteškega stanu. ${ }^{I I}$ Ta naj bi opravljal različne vojaške, tehnične, predvsem pa administrativne funkcije $\mathrm{z}$ nalogo, da bi utrdil rimsko oblast na območjih, ki so bila šele ne-

I I Jaroslav Šašel, Situla, Volume 30 - Opera Selecta: Zur Frühgeschichte der XV. Legion und zur Nordostgrenze der Cisalpina zur Zeit Caesars (Ljubljana: Narodni muzej), 469-477. 
davno osvojena in priključena cesarstvu. ${ }^{12}$ Kasnejše študije in raziskave so dodatno potrdile, da zaključki Sarie niso pravilni, saj jim nasprotuje epigrafsko, numizmatično in arheološko gradivo. ${ }^{13}$ Med vojaškimi napisi iz Emone sta po funkciji omenjena tudi intendant petnajste Apolonove legije (št. 4) in zastavonoša ali nosilec znaka (signifer) trinajste Dvojne legije (št. 3).

Iz Petovione in njene okolice je znanih devetnajst vojaških napisov: trinajst nagrobnih napisov (št. I4, 15, I8/19, 20, 21, 23, 24, 25, 27, 28, 29, 31 in 32), štirje oltarji (št. $16,17,22$ in 33) in dva spomenika za katera ni mogoče natančno določiti vrste (št. 26 in 29).

$\mathrm{Na}$ petih spomenikih so izpričani veterani, pri tem so v štirih primerih (št. 29, 30, 31 in 33) enote navedene in $\mathrm{v}$ enem ne (št. 32). Veterani so na štirih napisih izpričani z oznako veteranus (št. $29,31,32$ in 33), medtem ko oznaka missicio nepoznanega vojaka (št. 30) izpričuje status odsluženega vojaškega roka. Starost vojakov je možno razbrati na petih napisih (št. 29, 21, 23, I 4 in 28). Zaokrožena je na 5 ali io let: 85 (št. 29), 70 (št. 26), 30 (št. I4) in 65 (št. 28) let, medtem ko nagrobnik Marka Avrelija (ime je nepopolno) navaja II let službovanja v neznani kohorti, iz česar lahko sklepamo, da je vojak imel vsaj 29 let, ko je preminil. ${ }^{\mathrm{It}} \mathrm{Na}$ nagrobniku je navedeno, da je bil veteran. Iz tega lahko sklepamo, da je bil vojak starejši in je bil II let pred smrtjo najverjetneje premeščen $\mathrm{v}$ drugo enoto. $\mathrm{Z}$ oznako miles je izpričanih pet vojakov (št. 23, 24, 25, 26 in 27), prav tako se pojavi še na nagrobniku tribunskega beneficiarija Kaja Kornelija Prokula (št. I4).

Pripadnost vojakov posameznim enotam je navedena na osemnajstih napisih. Osma Avgustova legija je izpričana na treh napisih (št. I5, 2I in 30), trinajsta Dvojna legija pa na šestih napisih (št. 23, 24, I 4, 25, 31 in I7), štirinajsta Gemina na treh (št. 26, 27 in 28), deseta Gemina (št. 16),

I2 Marjeta Šašel Kos, "Colonia Iulia Emona - the genesis of the Roman city," Arheološki vestnik 63 (2012), 100.

I3 Mitja Gaspari, »Apudhorridas gentis ...«začetki rimskega mesta Colonia Iulia Emona = beginnings of the Roman town of Colonia Iulia Emona (Ljubljana: muzej in galerije mesta Ljubljane, 2010), I 13 ; Šašel Kos, "Colonia Iulia Emona - the genesis of the Roman city," Iоo.

I4 Jevremov, Vodnik po lapidarju I. del, 71, no. 50. četrta Flavija Srečna (št. 33), enajsta Klavdijeva (št. 29) in prva Pomožna (št. 20) pa po enkrat. Med vojaškimi enotami je omenjen še desetnik konjeniškega oddelka prve Traške ale (decurio alae I Thracum) (št. 22). Na sarkofagu postavljenem $\mathrm{v}$ spomin preminulima staršema iz Vičave (št. I8), je navedeno, da sta naročnika sinova, ki sta vojaško službo opravljala kot načelnika oziroma polkovnika pomožnih enot: prva Germanska (Cohors I Germanorum) in druga Hispanska kohorta (Cohors II Hispanorum).

Iz Drnovega pri Krškem, kjer se je nekoč razprostiral rimski municipij Neviodunum, je vse rimske napise neviodunskega agra zbral in ovrednotil M. Lovenjak, ${ }^{15}$ vojaški napisi pa še niso bili strnjeno dokumentirani ali obravnavani. Dvanajst tovrstnih napisov je bilo najdenih $\mathrm{v}$ neposredni bližini antičnega mesta. Največ jih je iz Velikih Malenc ( 5 napisov) in Krške vasi ( 3 napisi) ter po en primer iz Leskovca pri Krškem, Valične vasi, Čateža in Dobove.

Po številu največ beneficiarskih napisov, ki jih sestavlja devet votivnih oltarjev (št. 35, 36, 37, $38,39,40,41,42$ in 43 ) in nagrobni napis (št. 44) konzularjevega beneficiarija iz obdobja druge polovice 2. in prve polovice 3. st.

Napisi št. 35, 40, 4I in 42 so bili najdeni na hribu Gradišče pri Velikih Malencah, kjer se je od 2. st. dalje nahajal poznorimski utrjeni kastel, ki je branil in nadzoroval rimsko cesto še $\mathrm{v}$ 6. st. ${ }^{16} \mathrm{Na}$ treh napisih sta poleg funkcije konzularjevega beneficiarija omenjeni tudi legiji v katerih so beneficiariji službovali. Na napisih št. 35 in 40 je navedena deseta Dvojna legija, na napisu št. 4I pa štirinajsta Dvojna legija $\mathrm{z}$ vzdevkom Martia victrix (Marsova zmagovita) (št. 4I). Med predstavniki vojske sta iz napisov omenjena Publij Maksimij Matern, ki je kot merilec desete Dvojne legije verjetno sodeloval pri postavljanju vojaških taborov svoje legije, in Maksimij Mansuet, ki je svojo službo opravljal kot centurion dvanajste Bliskovite legije. Mansuet je na-

I5 Lovenjak, Situla, Volume 37: Neviodunum - Inscriptiones Latinae Slovenia (ILSl) I, I4I-142.

Iva Mikl Curk, Slavko Ciglenečki and Davorin Vuga, Po poteh rimskih vojakov v Sloveniji (Ljubljana: Zavod Republike Slovenije za varstvo naravne in kulturne dediščine Slovenije, 1993), 193. 
Tabela s: Predstavniki vojske v Neviodunu

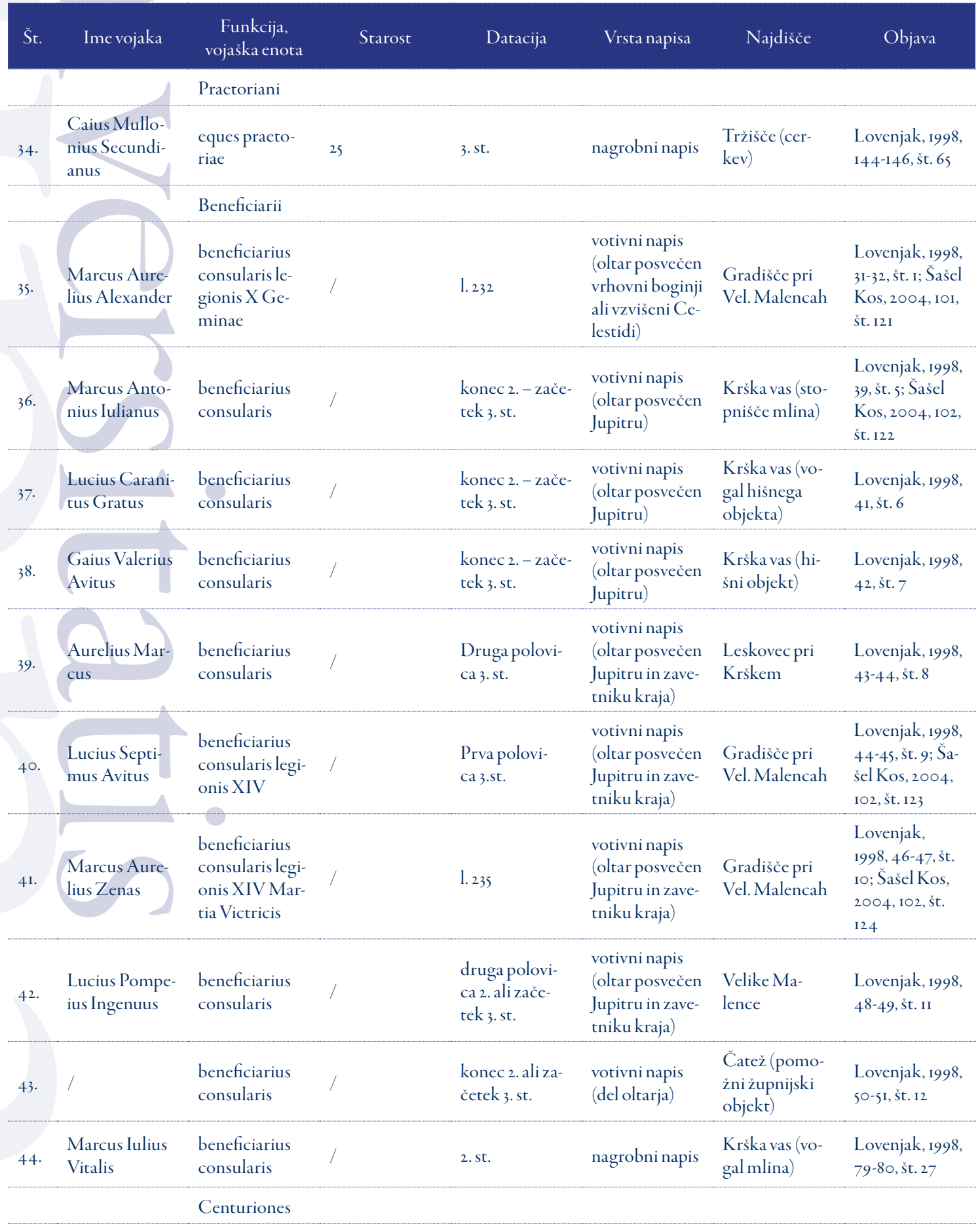




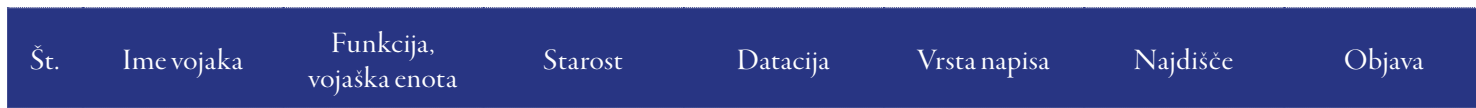

\begin{tabular}{|c|c|c|c|c|c|c|c|}
\hline 45. & $\begin{array}{l}\text { Maximius } \\
\text { Mansuetus }\end{array}$ & $\begin{array}{l}\text { Centurio legi- } \\
\text { onis XII Ful- } \\
\text { minatae }\end{array}$ & / & verjetno i. st. & nagrobni napis & $\begin{array}{l}\text { Dobova (cer- } \\
\text { kev) }\end{array}$ & $\begin{array}{l}\text { Lovenjak, } 1998, \\
\text { I4I-I } 42 \text {, št. } 64\end{array}$ \\
\hline
\end{tabular}

Mensores

\begin{tabular}{|c|c|c|c|c|c|}
\hline $\begin{array}{l}\text { Publius Maxi- } \\
\text { mius Mater- } \\
\text { nus }\end{array}$ & $\begin{array}{l}\text { Mensor legio- } \\
\text { nis X Geminae }\end{array}$ & I. 240 & $\begin{array}{l}\text { votivni napis } \\
\text { (oltar posvečen } \\
\text { rojakom) }\end{array}$ & $\begin{array}{l}\text { Valična vas } \\
\text { (cerkev sv. } \\
\text { Martina) }\end{array}$ & $\begin{array}{l}\text { Lovenjak, 1998, } \\
\text { 132-133, št. } 60\end{array}$ \\
\hline
\end{tabular}

Milites

$\begin{array}{ll}\text { 47. } \begin{array}{l}\text { Vibius Eme- } \\ \text { ritus }\end{array} & \begin{array}{l}\text { miles legionis } \\ \text { X Geminae }\end{array} \\ & \text { Veterani }\end{array}$

\begin{tabular}{|c|c|c|c|c|c|c|c|}
\hline 48. & $\begin{array}{l}\text { Lucius Mar- } \\
\text { cius Blandus }\end{array}$ & $\begin{array}{l}\text { veteranus ex } \\
\text { decurio... No- } \\
\text { ricorum }\end{array}$ & / & $\begin{array}{l}\text { prva polovica } \\
\text { 2.st. }\end{array}$ & nagrobni napis & $\begin{array}{l}\text { Veliki Korinj } \\
\text { (cerkev) }\end{array}$ & $\begin{array}{l}\text { 1998, I } 40-141 \text {, } \\
\text { št. 63; Šašel } \\
\text { Kos, 2004, 105, } \\
\text { št. I39 }\end{array}$ \\
\hline 49. & $\begin{array}{l}\text { Caius Mullo- } \\
\text { nius Verus }\end{array}$ & $\begin{array}{l}\text { veteranus le- } \\
\text { gionis X Ge- } \\
\text { minae }\end{array}$ & / & 3. st. & nagrobni napis & $\begin{array}{l}\text { Tržišče (cer- } \\
\text { kev) }\end{array}$ & $\begin{array}{l}\text { Lovenjak, } 1998 \\
\text { 144-1 } 46, \text { št. } 65\end{array}$ \\
\hline
\end{tabular}

grobnik dal postaviti v čast svoji tašči in materi Juliji Pompeji. ${ }^{17} \mathrm{Na}$ napisu je navedeno, da je Mansuet službo centuriona opravljal v dvanajsti Bliskoviti legiji. Datacijo nagrobnika je Lovenjak postavil v čas okoli i. st. ${ }^{18}$ Vendar pa Kasij Dion v svoji Rimski zgodovini legijo navaja v povezavi z nevihto, ki je vojake rešila pred neizbežnim porazom. Kasij Dionova navedba časovno in prostorsko dvanajsto Bliskovito legijo postavlja v leto 172 n. št, ko se je ta iz Melitene v Kapadokiji (Cappadocia; današnja provinca Nevşehir, Turčija) odpravila na vojaški pohod z Markom Avrelijem proti Kvadom na območje današnje Slovaške. ${ }^{19}$ Vojaški pohod je verjetno potekal tudi preko ozemlja današnje Slovenije in se nadaljeval proti severu, zato je možno, da je Man-

\footnotetext{
17 Lovenjak, Situla, Volume 37: Neviodunum - Inscriptiones Latinae Slovenia (ILSl) I, I 4 I-I 42 .

I8 Lovenjak, Situla, Volume 37: Neviodunum - Inscriptiones Latinae Slovenia (ILSl) I, 142 .

I9 Cassius Dio, Rhomaike historiae, $72=7$ 1.8-10.
}

suet poveljeval eni od centurij namenjeni v boj proti Kvadom in dal v tem obdobju postaviti nagrobni napis. Po Kasiju Dionu je mogoče povzeti, da je Lovenjak datacijo nagrobnika postavil v prezgodnji čas. Nagrobnik je zaradi tega verjetno potrebno umestiti v drugo polovico 2. st., vendar je pri tem potrebno upoštevati, da podrobnosti o vojaškem pohodu in obeh bitkah še niso znani in da je dvanajsta Bliskovita legija nosila to ime že eno stoletje pred omenjenim dogodkom. ${ }^{20}$

V Pretoriju Latobikov (Praetorium Latobicorum; današnje Trebnje) se je od 2. st. n. št. dalje nahajala pomembna prometna postojanka in vojaška točka. ${ }^{21}$ Postaja je upravno pripadala mu-

\footnotetext{
20 Marjeta Šašel Kos, Zgodovinska podoba prostora med Akvilejo, Jadranom in Sirmijem pri Kasiju Dionu in Herodijanu (Ljubljana: Slovenska akademija znanosti in umetnosti, 1986), 247, 249.

2 I Marjeta Šašel Kos, Zgodovinska podoba prostora med Akvilejo, Jadranom in Sirmijem pri Kasiju Dionu in Herodijanu, 377; Iva Mikl Curk, Slavko Ciglenečki and Davorin Vuga, Po poteh rimskih vojakov v Sloveniji (Ljubljana: Zavod Republike Slovenije za varstvo naravne in kulturne dediščine Slovenije, 1993), 47.
} 
Tabela 6: Predstavniki vojakov v Pretoriju Latobikov

\begin{tabular}{|c|c|c|c|c|c|c|c|}
\hline Št. & Ime vojaka & $\begin{array}{c}\text { Funkcija, } \\
\text { vojaška enota }\end{array}$ & Starost & Datacija & Vrsta napisa & Najdišče & Objava \\
\hline & & Beneficiarii & & & & & \\
\hline 50. & $\begin{array}{l}\text { Caius An- } \\
\text { tistius Threp- } \\
\text { tus }\end{array}$ & $\begin{array}{l}\text { beneficiarius } \\
\text { consularis }\end{array}$ & / & konec 2. ali 3. st. & $\begin{array}{l}\text { votivni napis } \\
\text { (oltar posvečen } \\
\text { Jupitru) }\end{array}$ & Trebnje & $\begin{array}{l}\text { Šašel Kos, } \\
2004,107, \\
\text { št. } 152\end{array}$ \\
\hline 51. & $\begin{array}{l}\text { Caius An- } \\
\text { tistius Ma- } \\
\text { turus }\end{array}$ & $\begin{array}{l}\text { beneficiarius } \\
\text { consularis }\end{array}$ & / & $\begin{array}{l}\text { verjetno konec } \\
\text { 2.st. }\end{array}$ & $\begin{array}{l}\text { votivni napis } \\
\text { (oltar Jupitru) }\end{array}$ & Trebnje & $\begin{array}{l}\text { Šašel Kos, } \\
2004,107, \\
\text { št. } 153\end{array}$ \\
\hline 52. & $\begin{array}{l}\text { Tiberius Cla- } \\
\text { udius Pereg- } \\
\text { rinus }\end{array}$ & $\begin{array}{l}\text { beneficiarius } \\
\text { consularis }\end{array}$ & / & $\begin{array}{l}\text { konec } 2 . \text { ali za- } \\
\text { četek 3. st. }\end{array}$ & $\begin{array}{l}\text { votivni napis } \\
\text { (oltar posvečen } \\
\text { Jupitru) }\end{array}$ & Trebnje & $\begin{array}{l}\text { Šašel Kos, } \\
2004,107, \text { št. } \\
154\end{array}$ \\
\hline 53. & $\begin{array}{l}\text { Lucius Clodius } \\
\text { Priscus }\end{array}$ & $\begin{array}{l}\text { beneficiarius } \\
\text { legati consu- } \\
\text { laris }\end{array}$ & / & $\begin{array}{l}\text { konec } 2 \text {. ali za- } \\
\text { četek 3. st. }\end{array}$ & $\begin{array}{l}\text { votivni napis } \\
\text { (oltar posvečen } \\
\text { Jupitru) }\end{array}$ & Trebnje & $\begin{array}{l}\text { Šašel Kos, } \\
2004,108, \text { št. } 155\end{array}$ \\
\hline 54. & $\begin{array}{l}\text { Titus Iullius } \\
\text { Firminus }\end{array}$ & $\begin{array}{l}\text { beneficiarius } \\
\text { consularis }\end{array}$ & / & druga pol. 2. st. & $\begin{array}{l}\text { votivni napis } \\
\text { (oltar posvečen } \\
\text { Jupitru) }\end{array}$ & Trebnje & $\begin{array}{l}\text { Šašel Kos, } \\
2004,108, \\
\text { št. } 156\end{array}$ \\
\hline 55. & $\begin{array}{l}\text { Caius Nove- } \\
\text { tius Restitutus }\end{array}$ & $\begin{array}{l}\text { ex benecifia- } \\
\text { rius consularis } \\
\text { veteranus legi- } \\
\text { onis I Adiutri- } \\
\text { cis }\end{array}$ & / & $\begin{array}{l}\text { konec } 2 \text { ali za- } \\
\text { četek } 3 \text {. st. }\end{array}$ & $\begin{array}{l}\text { votivni napis } \\
\text { (oltar posvečen } \\
\text { Jupitru) }\end{array}$ & Trebnje & $\begin{array}{l}\check{S}_{\text {ašel Kos, }} \\
2004,108, \text { št. } \\
157\end{array}$ \\
\hline 56. & $\begin{array}{l}\text { Marcus Vi- } \\
\text { ctorius Victo- } \\
\text { rinus }\end{array}$ & $\begin{array}{l}\text { beneficiarius } \\
\text { consularis }\end{array}$ & / & 1. 195 & $\begin{array}{l}\text { votivni napis } \\
\text { (oltar posvečen } \\
\text { Jupitru) }\end{array}$ & Trebnje & $\begin{array}{l}\text { Šašel Kos, } \\
2004,108, \\
\text { št. } 158\end{array}$ \\
\hline 57. & $\begin{array}{l}\text { Marcus Aure- } \\
\text { lius Valentinus }\end{array}$ & $\begin{array}{l}\text { beneficiarius } \\
\text { consularis legi- } \\
\text { onis XIV Ge- } \\
\text { minae }\end{array}$ & / & $\begin{array}{l}\text { I. november } \\
247 / 248\end{array}$ & $\begin{array}{l}\text { votivni napis } \\
\text { (oltar posvečen } \\
\text { Jupitru Doli- } \\
\text { henskemu) }\end{array}$ & Trebnje & $\begin{array}{l}\text { Šašel Kos, } \\
2004,108, \\
\text { št. } 159\end{array}$ \\
\hline 58. & $\begin{array}{l}\text { Gaius Baebius } \\
\text { Marcellinus }\end{array}$ & $\begin{array}{l}\text { beneficiarius } \\
\text { consularis le- } \\
\text { gionis X Ge- } \\
\text { minae }\end{array}$ & / & 8. april 225 & $\begin{array}{l}\text { votivni napis } \\
\text { (oltar posvečen } \\
\text { Jupitru in vsem } \\
\text { drugim bogo- } \\
\text { vom in zavetni- } \\
\text { ku kraja) }\end{array}$ & Trebnje & $\begin{array}{l}\text { Šašel Kos, } \\
2004,109, \text { št. } \\
160\end{array}$ \\
\hline 59. & $\begin{array}{l}\text { Iulius Teren- } \\
\text { tius }\end{array}$ & $\begin{array}{l}\text { beneficiarius } \\
\text { consularis le- } \\
\text { gionis X Ge- } \\
\text { minae Severi- } \\
\text { anae }\end{array}$ & / & 6. oktober 224 & $\begin{array}{l}\text { votivni napis } \\
\text { (oltar posvečen } \\
\text { vsem bogovom } \\
\text { in zavetniku } \\
\text { kraja) }\end{array}$ & $\begin{array}{l}\text { Sv. Štefan pri } \\
\text { Trebnjem }\end{array}$ & $\begin{array}{l}\text { Šašel Kos, } \\
2004,109, \\
\text { št. 161 }\end{array}$ \\
\hline
\end{tabular}




Št. Ime vojaka $\begin{gathered}\text { Funkcija, } \\ \text { vojaška enota }\end{gathered} \quad$ Starost $\quad$ Datacija $\quad$ Vrsta napisa $\quad$ Najdišče $\quad$ Objava

\begin{tabular}{|c|c|c|c|c|c|c|c|}
\hline 60. & $\begin{array}{l}\text { Aurelius Se- } \\
\text { cundianus / } \\
\text { Itrius }\end{array}$ & $\begin{array}{l}\text { beneficiarius } \\
\text { consularis le- } \\
\text { gionis X Ge- } \\
\text { minae }\end{array}$ & / & I8. maj, 3. st. & $\begin{array}{l}\text { votivni napis } \\
\text { (oltar posvečen } \\
\text { Jupitru in zave- } \\
\text { tniku kraja) }\end{array}$ & Trebnje & $\begin{array}{l}\text { Šašel Kos, } \\
2004,109, \text { št. } \\
162\end{array}$ \\
\hline 61. & $\begin{array}{l}\text { Marcus Aure- } \\
\text { lius Valentinus }\end{array}$ & $\begin{array}{l}\text { beneficiarius } \\
\text { consularis legi- } \\
\text { onis XIV Ge- } \\
\text { minae }\end{array}$ & / & $\begin{array}{l}\text { I. november, } \\
\text { verjetno l. } 247\end{array}$ & $\begin{array}{l}\text { votivni napis } \\
\text { (oltar posvečen } \\
\text { Jupitru in zave- } \\
\text { tniku kraja) }\end{array}$ & Trebnje & $\begin{array}{l}\text { Šašel Kos, } \\
2004,109, \text { št. } \\
163\end{array}$ \\
\hline 62. & $\begin{array}{l}\text { Candidius Ur- } \\
\text { sus }\end{array}$ & $\begin{array}{l}\text { beneficiarius } \\
\text { consularis legi- } \\
\text { onis XIV Ge- } \\
\text { minae }\end{array}$ & 1 & $\begin{array}{l}\text { 15. oktober, } \\
\text { 3. st. }\end{array}$ & $\begin{array}{l}\text { votivni napis } \\
\text { (oltar posvečen } \\
\text { Jupitru in zave- } \\
\text { tniku kraja) }\end{array}$ & Trebnje & $\begin{array}{l}\text { Šašel Kos, } \\
2004, \text { IIO, št. } \\
164\end{array}$ \\
\hline
\end{tabular}

\begin{tabular}{|c|c|c|c|c|c|c|}
\hline $\begin{array}{l}\text { Gaius Iulius } \\
\text { Dignus }\end{array}$ & $\begin{array}{l}\text { beneficiarius } \\
\text { consularis le- } \\
\text { gionis X Ge- } \\
\text { minae }\end{array}$ & / & I. oktober 250 & $\begin{array}{l}\text { votivni napis } \\
\text { (oltar posvečen } \\
\text { Jupitru in zave- } \\
\text { tniku kraja) }\end{array}$ & Trebnje & $\begin{array}{l}\text { Šašel Kos, } \\
2004, \text { IIO, št. } \\
165\end{array}$ \\
\hline
\end{tabular}

\begin{tabular}{|c|c|c|c|c|c|c|}
\hline $\begin{array}{ll}\text { Caius Iulius } \\
\text { 64. Impetratus }\end{array}$ & $\begin{array}{l}\text { beneficiarius } \\
\text { consularis le- } \\
\text { gionis X Ge- } \\
\text { minae }\end{array}$ & / & 15. oktober 257 & $\begin{array}{l}\text { votivni napis } \\
\text { (oltar posvečen } \\
\text { Jupitru in zave- } \\
\text { tniku kraja) }\end{array}$ & Trebnje & $\begin{array}{l}\text { Šašel Kos, } \\
2004 \text {, IIO, št. } \\
166\end{array}$ \\
\hline
\end{tabular}

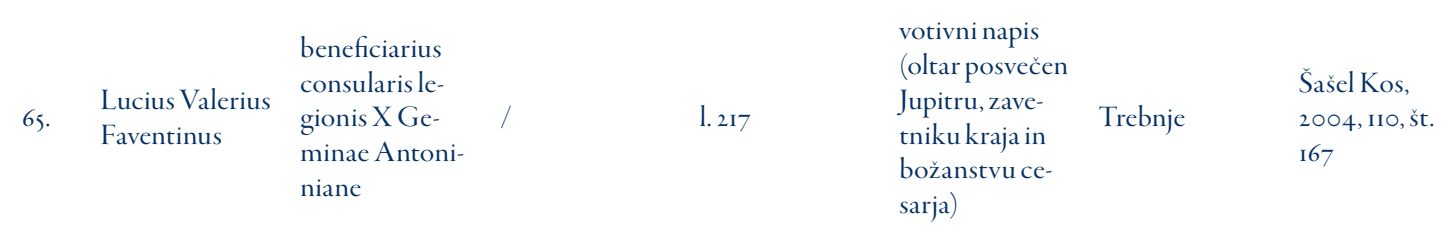

\begin{tabular}{|c|c|c|c|c|c|c|c|}
\hline 66. & $\begin{array}{l}\text { Lucius Varius } \\
\text { Suiranus }\end{array}$ & $\begin{array}{l}\text { beneficiarius } \\
\text { consularis }\end{array}$ & / & $\begin{array}{l}\text { 29. september } \\
240\end{array}$ & $\begin{array}{l}\text { votivni napis } \\
\text { (oltar oltar pos- } \\
\text { večen Jupitru } \\
\text { in zavetniku } \\
\text { kraja) }\end{array}$ & Trebnje & $\begin{array}{l}\text { Šašel Kos, } \\
2004, \text { III, št. } 168\end{array}$ \\
\hline 67. & / & $\begin{array}{l}\text { beneficiarius } \\
\text { consularis }\end{array}$ & / & 1.232 & $\begin{array}{l}\text { votivni napis } \\
\text { (spodnji del ol- } \\
\text { tarja) }\end{array}$ & Trebnje & $\begin{array}{l}\text { Šašel Kos, } \\
2004, \text { III, št. } 169\end{array}$ \\
\hline
\end{tabular}

nicipiju Nevioduna, vendar se je ta nahajala v neposredni bližini meje med provinco Panonijo in
Deseto italsko regijo, ki je potekala na območju današnje Stične. ${ }^{2}$

22 Marjeta Šašel Kos, "Cestni postaji Atrans in Pretorij Latobikov," in Zakladi tisočletij, ur. Bronislava Aubelj (Ljubljana: Modrijan, 1999), 239. 
Tabela 7: Predstavniki beneficiarijevv Celeji

\begin{tabular}{|c|c|c|c|c|c|}
\hline$\check{S}_{\mathrm{t}}$. & Ime beneficiarja & $\begin{array}{c}\text { Funkcija, } \\
\text { vojaška enota }\end{array}$ & Starost & Datacija & Prokurator \\
\hline & rocura- & & & & \\
\hline 68. & & $\begin{array}{l}\text { beneficiarius pro- } \\
\text { curator }\end{array}$ & / & 1. 110 & Memmius Apolinaris \\
\hline 69. & Antonius Maximus & $\begin{array}{l}\text { beneficiarius pro- } \\
\text { curator }\end{array}$ & / & 2. ali 3. desetletje 2. st. & Q. Caecilius Redditus \\
\hline 70. & L. Messius Frontinus & $\begin{array}{l}\text { beneficiarius pro- } \\
\text { curator }\end{array}$ & / & $\begin{array}{l}\text { I20 do neposredno } \\
\text { po } 135\end{array}$ & C. Censorius Niger \\
\hline 71. & M. Ulpius Crescens & $\begin{array}{l}\text { beneficiarius pro- } \\
\text { curator }\end{array}$ & / & $120-130$ & C. Censorius Niger \\
\hline 72. & Nonius? Primus & $\begin{array}{l}\text { beneficiarius pro- } \\
\text { curator }\end{array}$ & / & okoli I 40 & Plautius Caesianus \\
\hline 73. & Masclinius Successus & $\begin{array}{l}\text { beneficiarius pro- } \\
\text { curator }\end{array}$ & / & prva polovica 2. st. & C. Antistius Auspex \\
\hline 74 & Augustanu & $\begin{array}{l}\text { beneficiarius pro- } \\
\text { curator }\end{array}$ & / & prva polovica 2. st. & C. Rasinius Silo \\
\hline 75 & Gemellius Adiutor & $\begin{array}{l}\text { beneficiarius pro- } \\
\text { curator }\end{array}$ & / & prva polovica 2. st. & Drusius Proculus \\
\hline 76. & $\begin{array}{l}\text { Q. Crescentius Mar- } \\
\text { cellus }\end{array}$ & $\begin{array}{l}\text { beneficiarius pro- } \\
\text { curator }\end{array}$ & / & prva polovica 2. st. & Q. Lisinius Sabinus \\
\hline 77. & T. Flavius Dubitatus & $\begin{array}{l}\text { beneficiarius pro- } \\
\text { curator }\end{array}$ & / & prva polovica 2. st. & Q. Lisinius Sabinus \\
\hline 78. & C.Mustius Tettianus & $\begin{array}{l}\text { beneficiarius pro- } \\
\text { curator }\end{array}$ & / & prva polovica 2. st. & Lisinius Sabinus \\
\hline 79. & Lucilius Finitus & $\begin{array}{l}\text { beneficiarius pro- } \\
\text { curator }\end{array}$ & / & okoli I52-153 & Flavius Titianus \\
\hline $8 \circ$. & C. An $(\mathrm{t})$ onius Valens & $\begin{array}{l}\text { beneficiarius pro- } \\
\text { curator }\end{array}$ & / & $152-153$ & Flavius Titianus \\
\hline $8 \mathrm{r}$ & C. Fuscinius Catullus & $\begin{array}{l}\text { beneficiarius pro- } \\
\text { curator }\end{array}$ & / & $154-158$ & Ulpius Victor \\
\hline 82. & Adnamius Flavinus & $\begin{array}{l}\text { beneficiarius pro- } \\
\text { curator }\end{array}$ & / & okoli 158 & Ulpius Victor \\
\hline 83. & Adnamius Flavinus & $\begin{array}{l}\text { beneficiarius pro- } \\
\text { curator }\end{array}$ & / & okoli 158 & Usenius Secundus \\
\hline 84. & Q. Kaninius Lucanus & $\begin{array}{l}\text { beneficiarius pro- } \\
\text { curator }\end{array}$ & / & 158 & Usenius Secundus \\
\hline
\end{tabular}




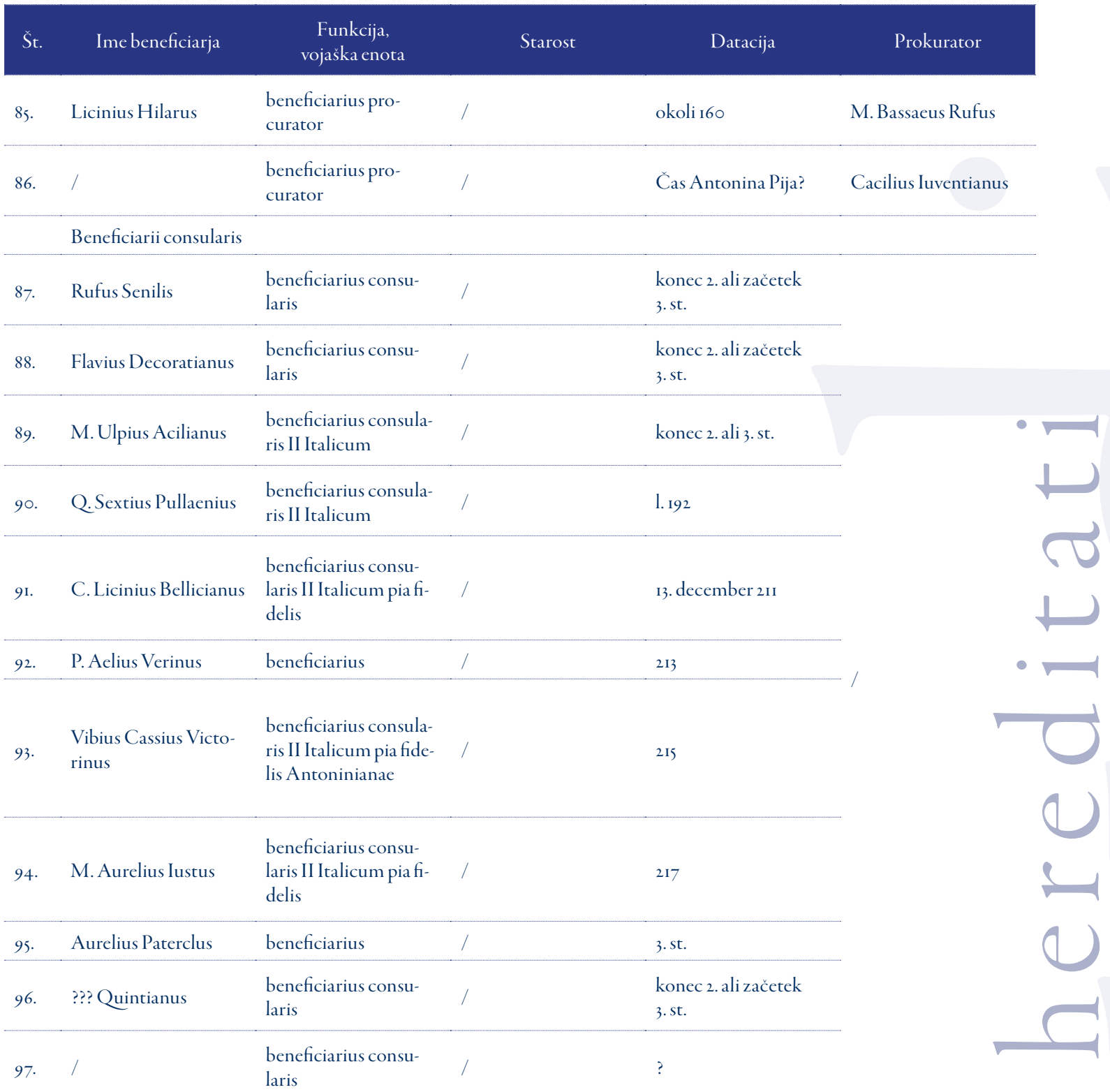

Vojaške napise iz Pretorija Latobikov in njegove okolice v celoti (osemnajst napisov) sestavljajo beneficiarski napisi. Med prevladujočimi napisi konzularjevih beneficiarijev sta po enkrat izpričana tudi konzularjev legat (št. 53) in nekdanji konzularjev beneficiarij, ki je na napis poleg oznake ex beneficiario consularis dodal tudi status veterana prve Pomožne legije (št. 55). Poleg omenjene legije sta na desetih primerih navede- ni še dve vojaški enoti. Štirinajsta Dvojna legija je izpričana na treh napisih (št. 57, 6I in 62), vendar glede na ime in datacijo lahko sklepamo, da je napisa št. 57 in 6I dala postaviti ista oseba. Deseta Dvojna legija je izpričana na napisih št. 58 , $59,60,63,64,65$ in 66 . Na napisu št. 58 je ime legije dopolnjeno z vzdevkom Severiana, po cesarski dinastiji Severov, na napisu št. 66 pa z Antoniniana, po cesarski dinastiji Antoninov. Oznaka 
Tabela 8: Predstavniki beneficiarijev v Celeji ${ }^{\mathrm{I}}$

\begin{tabular}{|c|c|c|c|c|c|}
\hline$\check{S}_{\mathrm{t}}$. & Ime beneficiarja & $\begin{array}{c}\text { Funkcija, } \\
\text { vojaška enota }\end{array}$ & Starost & Datacija & Prokurator \\
\hline & $\begin{array}{l}\text { Beneficiarii procura- } \\
\text { toris }\end{array}$ & & & & \\
\hline 68. & & $\begin{array}{l}\text { beneficiarius pro- } \\
\text { curator }\end{array}$ & / & l. nio & Memmius Apolinaris \\
\hline 69. & Antonius Maximus & $\begin{array}{l}\text { beneficiarius pro- } \\
\text { curator }\end{array}$ & / & 2. ali 3. desetletje 2. st. & Q. Caecilius Redditus \\
\hline 70. & L. Messius Frontinus & $\begin{array}{l}\text { beneficiarius pro- } \\
\text { curator }\end{array}$ & / & $\begin{array}{l}\text { I20 do neposredno } \\
\text { po } 135\end{array}$ & C. Censorius Niger \\
\hline $7 \mathrm{I}$. & M. Ulpius Crescens & $\begin{array}{l}\text { beneficiarius pro- } \\
\text { curator }\end{array}$ & / & $120-130$ & C. Censorius Niger \\
\hline 72. & Nonius? Primus & $\begin{array}{l}\text { beneficiarius pro- } \\
\text { curator }\end{array}$ & / & okoli I 40 & Plautius Caesianus \\
\hline 73. & Masclinius Successus & $\begin{array}{l}\text { beneficiarius pro- } \\
\text { curator }\end{array}$ & / & prva polovica 2.st. & C. Antistius Auspex \\
\hline 74. & Augustanus & $\begin{array}{l}\text { beneficiarius pro- } \\
\text { curator }\end{array}$ & / & prva polovica 2. st. & C. Rasinius Silo \\
\hline 75. & Gemellius Adiutor & $\begin{array}{l}\text { beneficiarius pro- } \\
\text { curator }\end{array}$ & / & prva polovica 2. st. & Drusius Proculus \\
\hline 76 & $\begin{array}{l}\text { Q. Crescentius Mar- } \\
\text { cellus }\end{array}$ & $\begin{array}{l}\text { beneficiarius pro- } \\
\text { curator }\end{array}$ & / & prva polovica 2. st. & Q.Lisinius Sabinus \\
\hline 77. & T. Flavius Dubitatus & $\begin{array}{l}\text { beneficiarius pro- } \\
\text { curator }\end{array}$ & / & prva polovica 2. st. & Q. Lisinius Sabinus \\
\hline 78. & C.Mustius Tettianus & $\begin{array}{l}\text { beneficiarius pro- } \\
\text { curator }\end{array}$ & / & prva polovica 2. st. & Lisinius Sabinus \\
\hline 79. & Lucilius Finitus & $\begin{array}{l}\text { beneficiarius pro- } \\
\text { curator }\end{array}$ & / & okoli 152-153 & Flavius Titianus \\
\hline $8 \circ$. & C. An $(\mathrm{t})$ onius Valens & $\begin{array}{l}\text { beneficiarius pro- } \\
\text { curator }\end{array}$ & / & $152-153$ & Flavius Titianus \\
\hline $8 \mathrm{I}$. & C. Fuscinius Catullus & $\begin{array}{l}\text { beneficiarius pro- } \\
\text { curator }\end{array}$ & / & $154-158$ & Ulpius Victor \\
\hline 82. & Adnamius Flavinus & $\begin{array}{l}\text { beneficiarius pro- } \\
\text { curator }\end{array}$ & / & okoli 158 & Ulpius Victor \\
\hline 83. & Adnamius Flavinus & $\begin{array}{l}\text { beneficiarius pro- } \\
\text { curator }\end{array}$ & / & okoli 158 & Usenius Secundus \\
\hline
\end{tabular}

Visočnik, "Vojaški napisi iz Celeje in njene okolice", 337. 


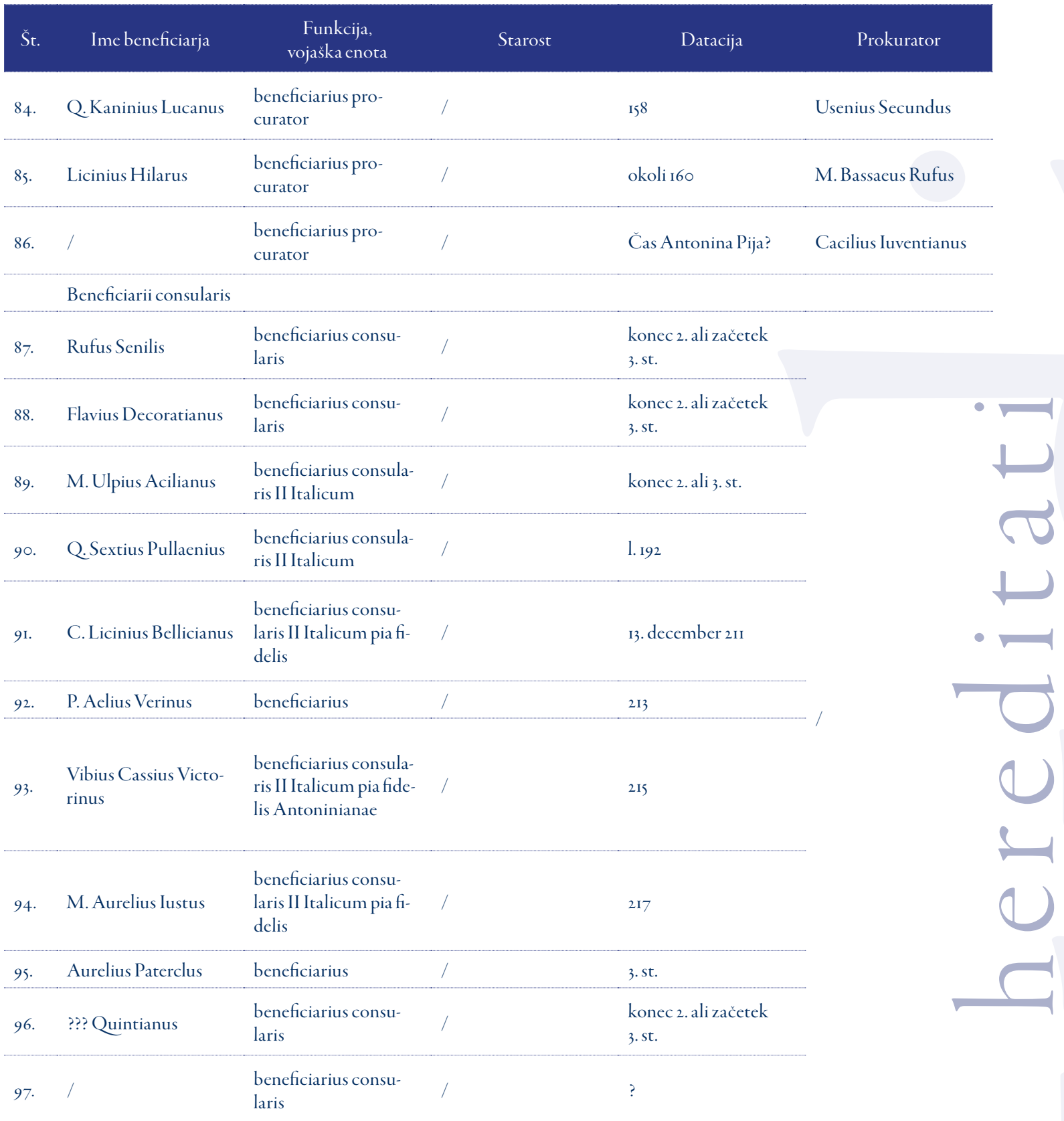

miles se pojavi tudi na oltarju konzularjevega beneficiarija Gaja Bebija Marcelina (št. 58).

Z območja Celeje se beneficiarski napisi delijo na dve skupini: na prokuratorjeve (do markomanskih vojn) in konzularjeve, ko provinco ni več upravljal prokurator, ampak legat. ${ }^{23}$

23 Visočnik, "Vojaški napisi iz Celeje in njene okolice", 335. 
Tabela 9: Predstavniki vojske na posamičnih lokacijah po Sloveniji
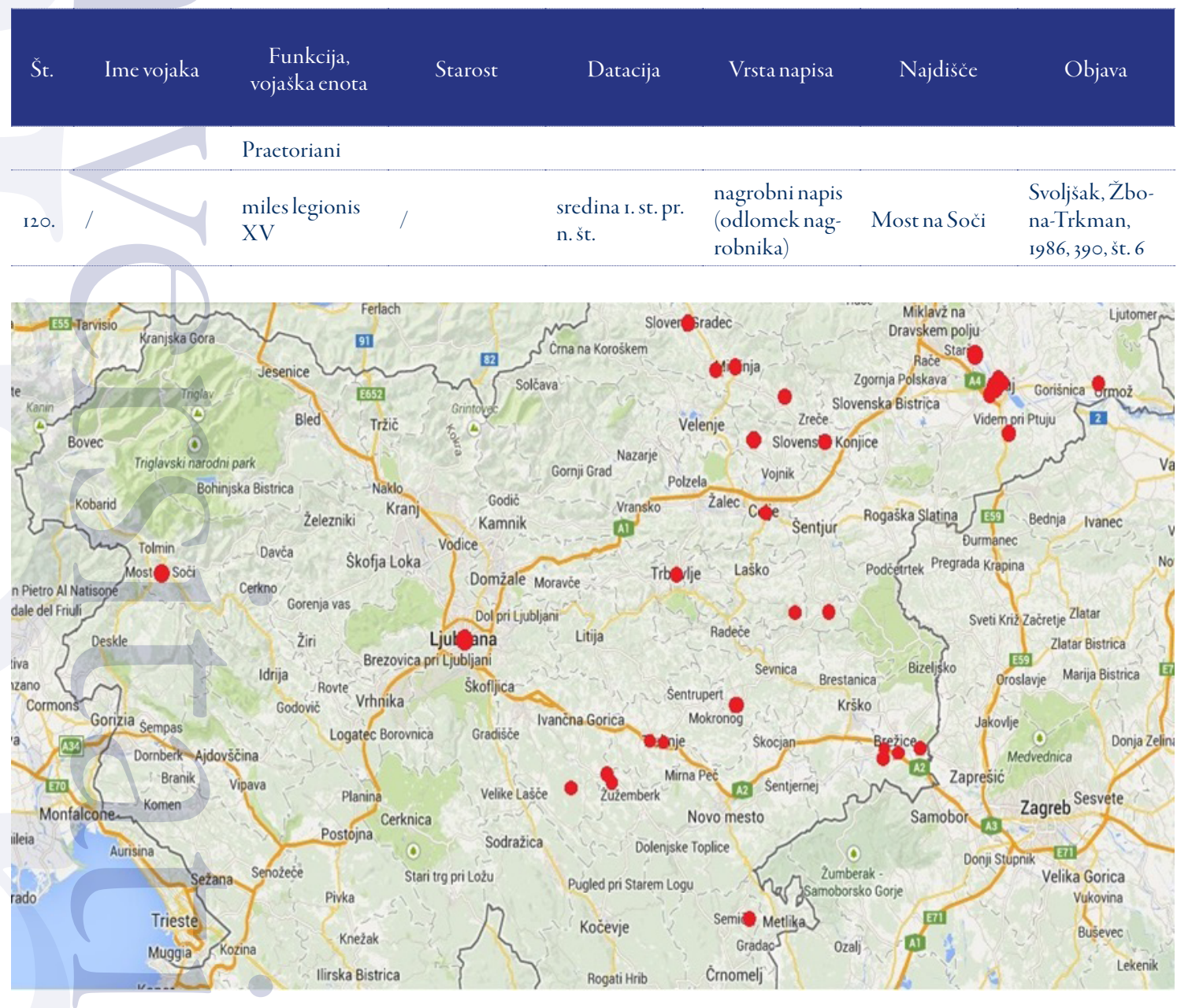

Slika I:Zemljevid, ki prikazuje število vojaških napisov na prostoru tromeje med Italijo, Norikom in Panonijo (zemljevid prirejen po https://maps.google.com/). 


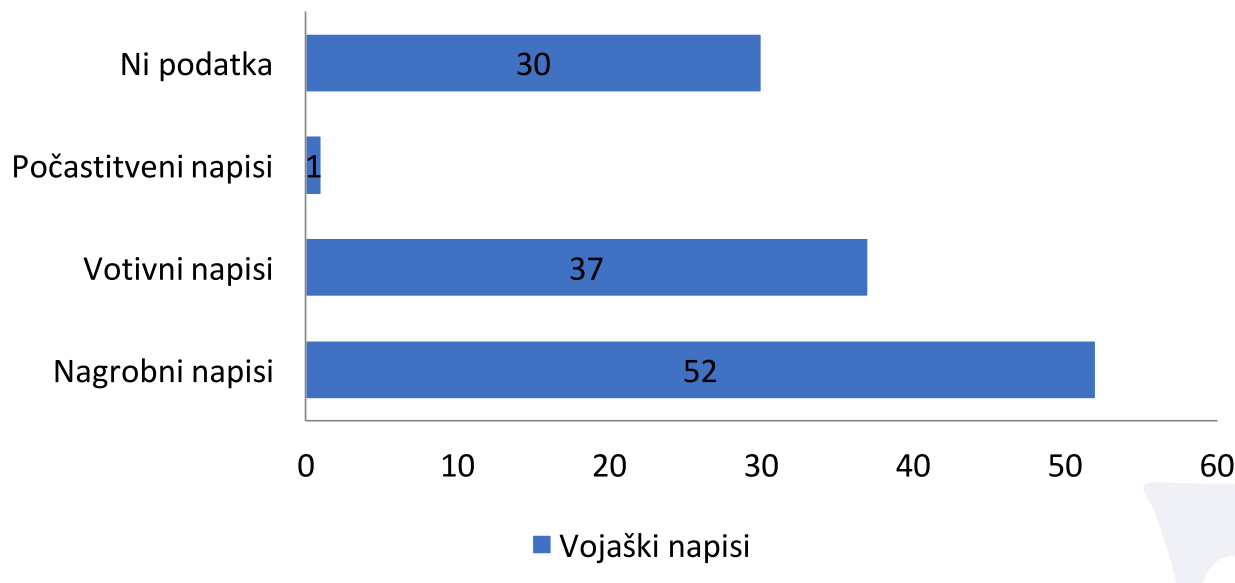

Graf I: Grafični prikaz števila vojaških napisov.

Opomba: V skupino »ni podatka« so vključeni vojaški napisi iz odlomljenih ali poškodovanih spomenikov, na katerih je napisno polje nečitljivo ali popolnoma odstranjeno.
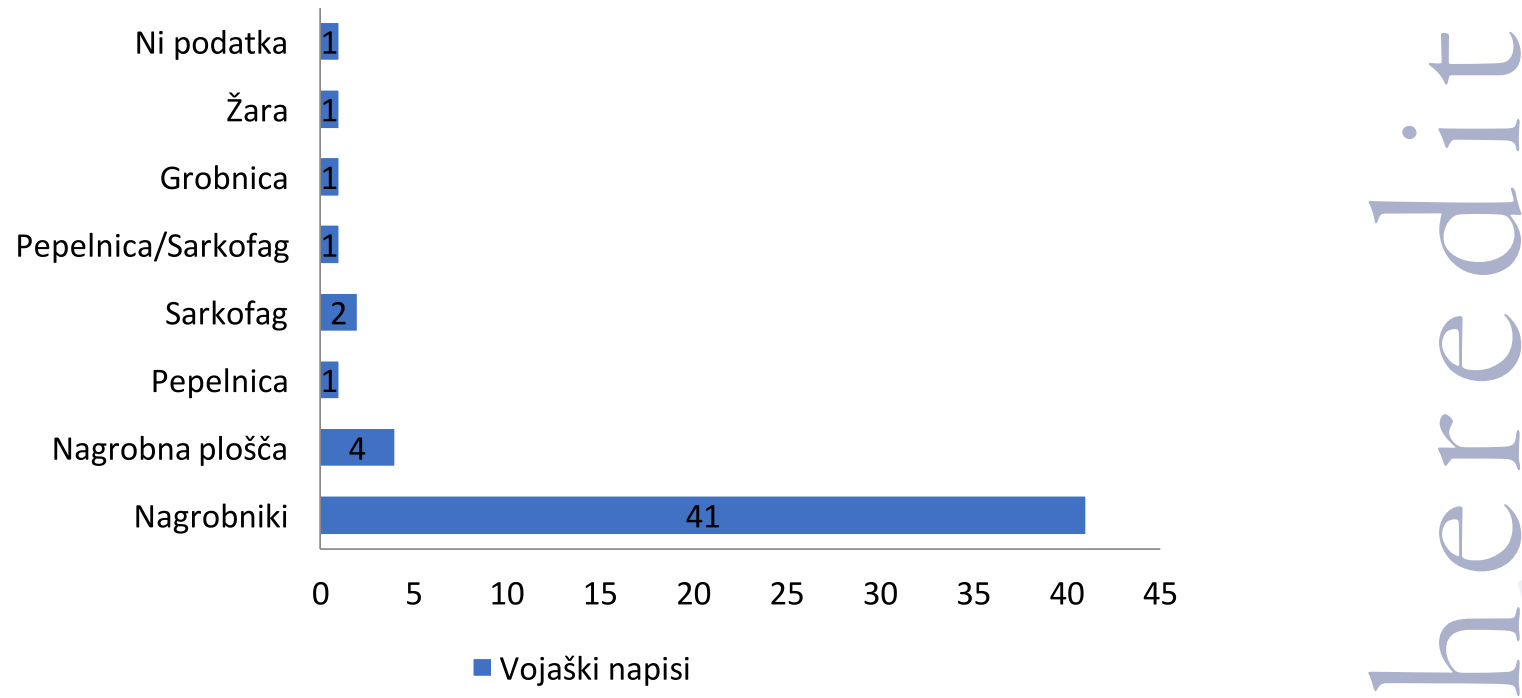

Graf 2: Grafični prikaz števila vojaških napisov glede na vrsto nagrobnega spomenika.

Opomba: V skupino »ni podatka« so vključeni nagrobni napisi iz odlomljenih ali poškodovanih spomenikov, na katerih je pisno polje nečitljivo ali popolnoma odstranjeno. 
Beneficiarii

Beneficiarii procuratores

Beneficiarii legati consularis

Beneficiarii consulari

Mensores

Decuriones

Primi Hastat

Optii

Praefecti

Centuriones

Beneficiarii tribuni

Miles

Veterani

Frumentrari

Signiferi

Praetoriani

Tribuni militium

Emona

0
Poetovio

$\stackrel{5}{\text { Neviodunum }}$

10 rium

- Celeia

Graf 3: Grafični prikaz števila rimskih vojakov na slovenskem prostoru glede na funkcijo.

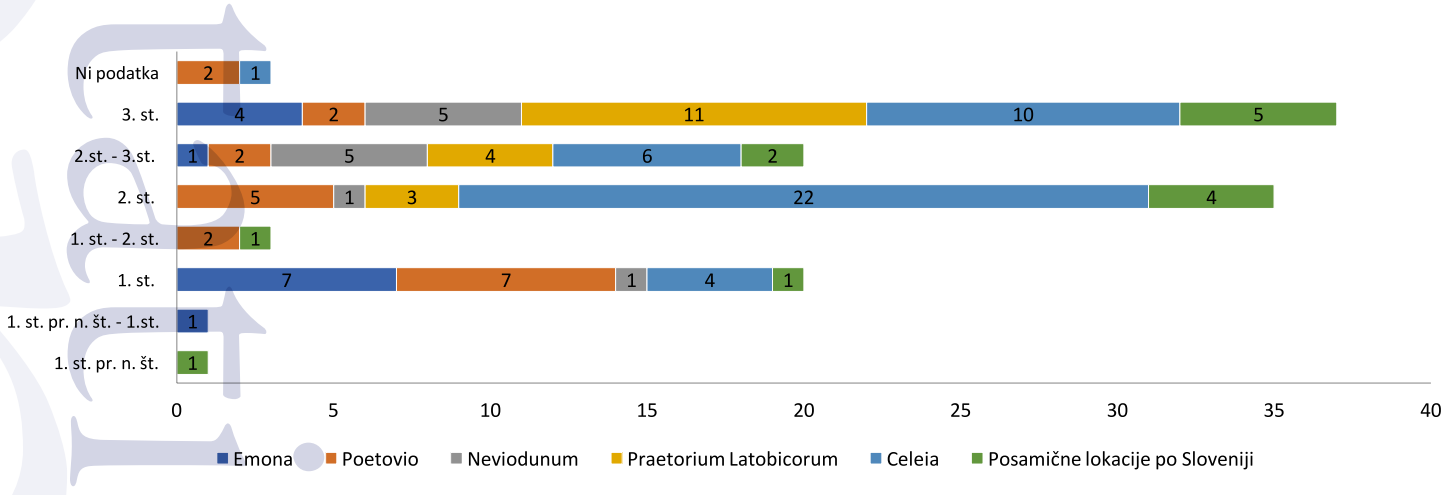

Graf 4: Grafični prikaz števila rimskih vojakov na slovenskem prostoru glede na obdobje.

Opomba: V skupino »ni podatka« so vključeni rimski vojaki iz odlomljenih ali poškodovanih spomenikov, na katerih je datacija nečitljiva ali popolnoma odstranjena. 


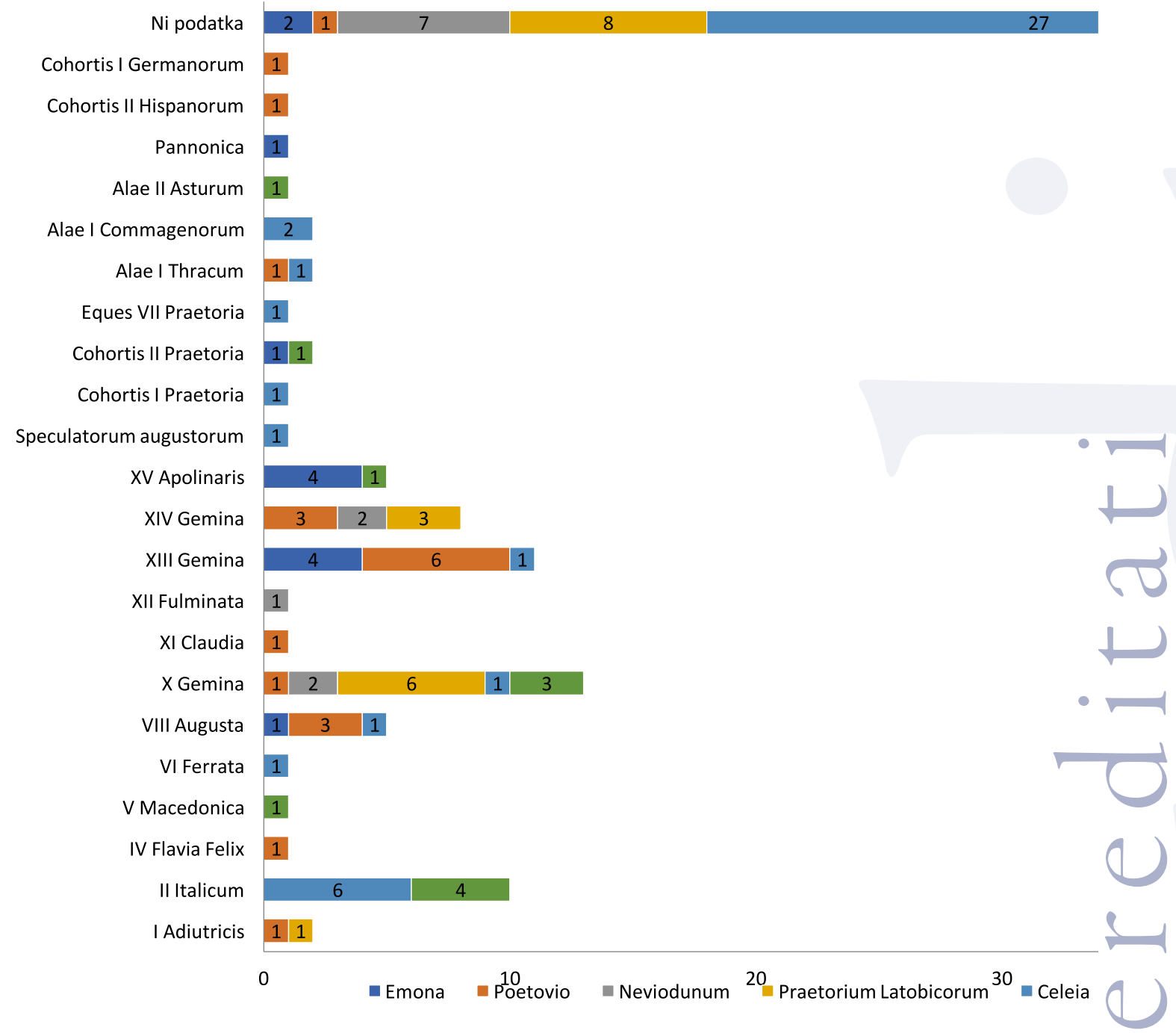

Graf 5: Grafični prikaz rimskih vojaških oddelkov omenjenih na obravnavanih napisih.

Opomba: V skupino »ni podatka« so vključeni rimski vojaki iz odlomljenih ali poškodovanih spomenikov, na katerih so podatki o pripadnosti k vojaškemu oddelku nečitljivi ali popolnoma odstranjeni. 


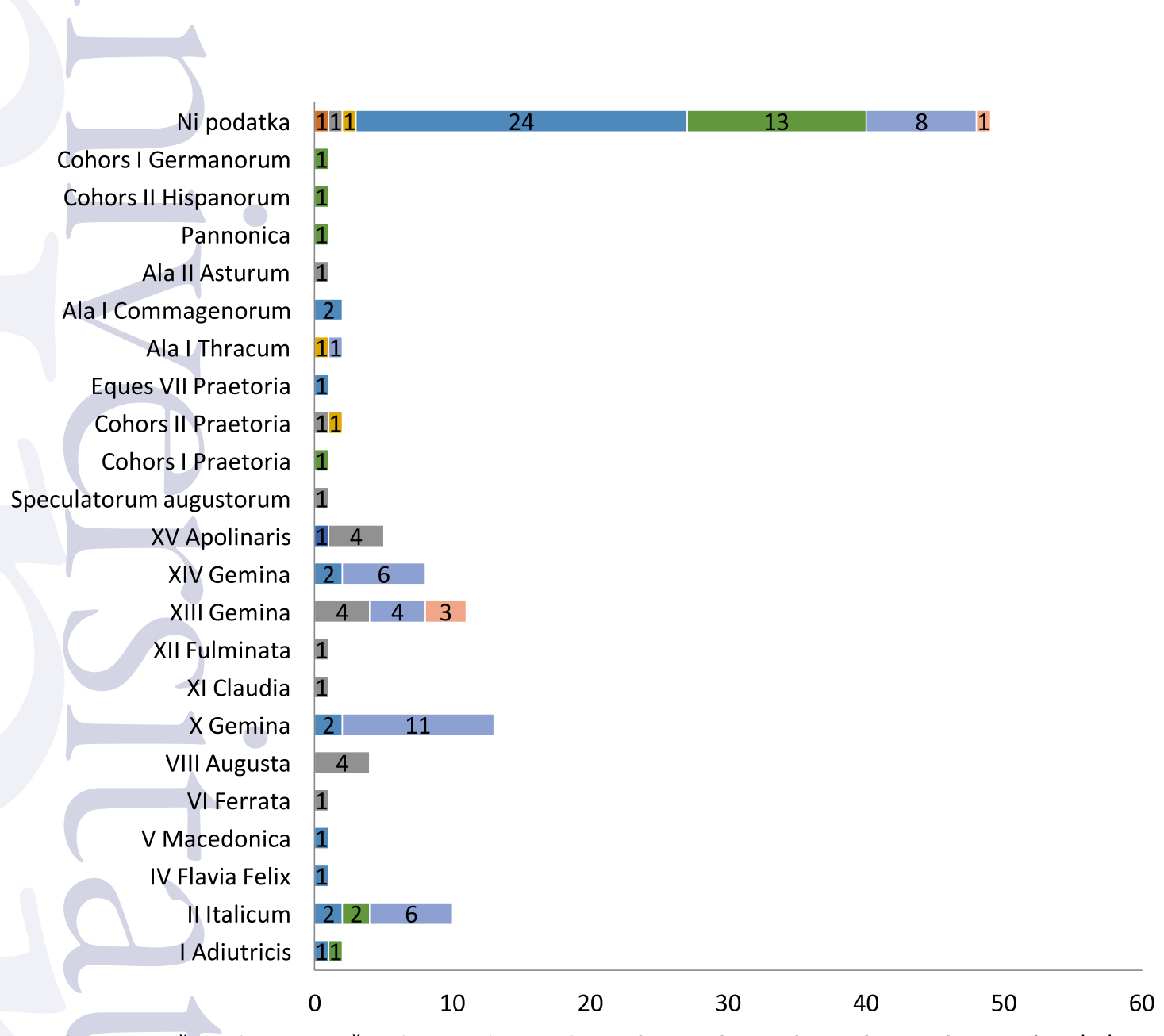

$\square$ 1. st. pr. n. št. $\square$ 1. st. pr. n. št. - 1. st. $\square$ 1. st. $\square 1$. st. - 2. st. $\square$ 2. st $\square$ 2. st. - 3. st. $\square$ 3. st $\square$ Ni podatka

Graf 6: Grafični prikaz rimskih vojaških oddelkov na slovenskem prostoru razvrščcnih po obdobjih.

Opomba: V skupino »ni podatka « so vključeni rimski vojaki iz odlomljenih ali poškodovanih spomenikov, na katerih so podatki o pripadnosti k vojaškemu oddelku nečitljivi ali popolnoma odstranjeni. 


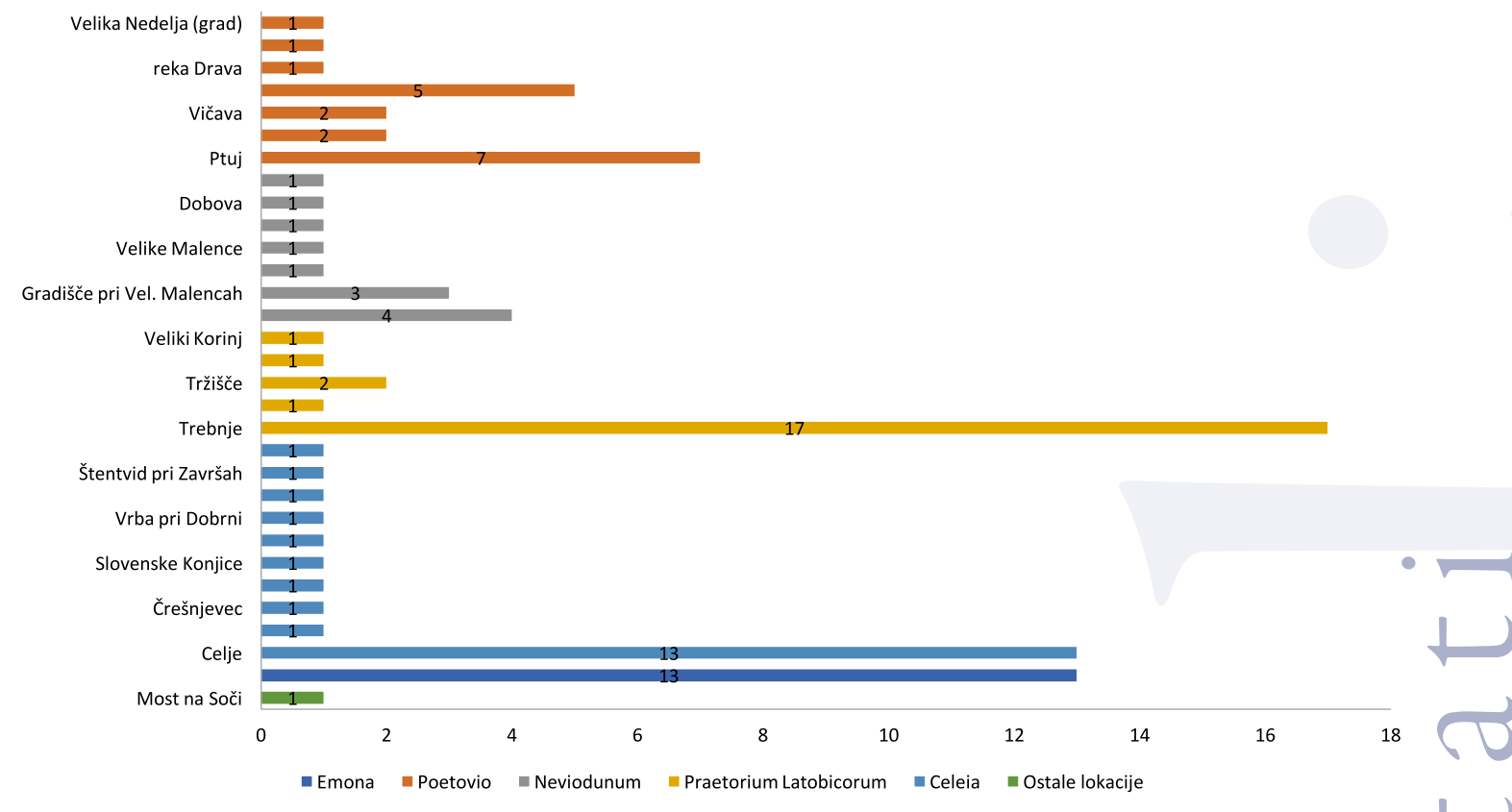

Graf 7: Grafični prikaz najdišč rimskih vojaških napisov v obravnavanem obdobju.

Opomba: V graf niso vključeni beneficiariji iz celejanskega prostora.

\section{Summary}

The large part of military inscriptions is represented by tombstones (gravestones, stelae, sarcophagi, tombs, cremation and cinerary urns) (look chart I and 2), while the lesser part is known from altars and dedications. The latter are votive inscriptions, often dedicated to deities, family members and friends. The overriding message on military inscriptions is primarily of memorial usage, but on some examples soldiers are also mentioned as dedicators or contributors (no. 5, II, I8/19, I06 and II3). Examples no. 21, 27, 44, 45, 49, 98/104, IOI and II9 testify that some soldiers used to order such tombstones during their lifetime for themselves and were later testamentary erected after they passed away.

From everything stated, it is clear that despite the modest number of existing and documented military inscriptions found all over Slovenia, they confirm the presence of Roman soldiers in this area. The increased number of military inscriptions from the $\mathrm{I}^{\mathrm{st}}$ and $2^{\text {nd }}$ century (see chart 4) can be attributed to the intensive expansion of the Roman Empire in the Southeast Europe- an region towards the Balkans and the subsequent war developments within the Empire.

Military inscriptions from Emona, Petovio, Neviodunum, Prateorium Latobicorum, Celeia and other individual locations all over Slovenia mostly belonged to the beneficiarii, common legionaries, praetorians, centurions and veterans; in three cases (no. 48, 55 and II5) it is also clear the function and the department unit in which these veterans served.

On military inscriptions found all over Slovenia are mentioned Apollo's Fifteenth Legion, Augustus' Eighth Legion, Thirteen Twin Legion, Italian Second Legion and individual units of the Hispanic Ninth legion and the Fourteenth Twin legion, the Rescuer First Legion, Lucky Flavian Fourth Legion, Macedonian Fifth Legion, Sixth Ironclad legion, Tenth Twin Legion, the Thunderbolt Twelfth Legion and Thirteenth Twin Legion.

Among praetorian troops the second cohort is mentioned twice, while the first praetorian cohort and the seventh praetorian cavalry cohort only once. Beside praetorian troops, the inscription no. 98 mentions a commander of a reconnaissance unit of praetorians. 
Among inscriptions of auxiliary troops there are also two mentions of the first and second horse unit - alae of Thracians and Commageni, while units of the first Hispanic cohort, first Germanic cohort and the horse unit of Asturi are all mentioned once.

Examples of military inscriptions from Emona of the Ist century AD (see chart 5 and 6) prove only that the Apollo's Fifteenth Legion and the Augustus' Eighth Legion participated in the conquest of the Cisalpine Gaul and the Western Balkan territories against indigenous people. Furthermore evidence can be found on military inscriptions from Petovio, specifically those attributed to the Augustus' Eight Legion (see chart 5 and 6) of which soldiers built a military camp in the vicinity of today's Ptuj.

After the second half of the ist century AD the number of representatives of the Thirteenth Twin Legion is increased among inscriptions (see chart 6). These inscriptions give further evidence to the already known ancient sources about the presence and accommodation of the Thirteenth Twin Legion in Petovio's region. In ancient sources the Thirteen Twin Legion was mentioned by Tacitus in relation to the year of four emperors.

In Neviodunum and Praetorium Latobicorum inscriptions can be connected with the beneficiarii (see chart 3), which in most cases are altars and dedications intended for gods and other deities. Most of the inscriptions are dedicated to Jupiter and several local patrons. On inscriptions no. 3 and 58 , Jupiter is known as Jupiter Dolichenus. In the Roman Empire during the $2^{\text {nd }}$ and $3^{\text {rd }}$ century the cult of Jupiter Dolichenus was widespread especially among soldiers. In Pannonia it flourished during the Severan dynasty. Some examples of these inscriptions were dedicated to individual goddesses (no. 4 , 17,33 and 35 ) or all gods (no. 58 and 59 ) and in one case also to compatriots (no. 46). Most of these votive inscriptions belonged to the beneficiarii and are accurately dated to the $2^{\text {nd }}$ and $3^{\text {rd }}$ century (no. 57, 58, 59, 60, 61, 62, 63, 64 and 66), i.e. during this period in provincial towns the Empire established important offices and institutions, which were managed by the beneficiarii.

None of the dedicators or contributors was an ordinary soldier: Valerius Aemilianus (no. 3) was a sign-bearer, Vibius (no. 4) was a superintendent, Martial (no. 17) and Lucius Septimius Tertinius (no. IO5) were centuri- ons, Gaius Cassius Silvester (no. 33) was a veteran, Publius Maximius Maternus (no. 46) was a measurer and others (no. 35, 36, 37, 38, 39, 40, 41, 42, 43, 44, 45, 50, 51, 52, $53,54,55,56,57,58,59,60,61,62,63,64,65,66$ and 67) were all beneficiarii.

Many roman military inscriptions found all over Slovenia were scattered on different locations in Dolenjska, Bela Krajina (Tržišče, Šmihel near Žužemberk, Veliko Korinje near Žužemberk) and Styria (Črešnjevec, Slovenj Gradec, Slovenske Konjice, Hudinja near Vitanje and Vrba near Dobrna), from which can be concluded, that these places were included in the wider hinterland of provincial towns of Celeia, Petovio and Neviodunum. In the far west of Slovenia, in Grad near Reka was found a cemetery with 149 graves. Among finds there was a tombstone belonging to a military soldier of the Fifteenth Legion (no. 120), dated between 53 and ${ }_{31} \mathrm{BC}$.

Expected differences can be spotted between cities, which are already visible by the number of military inscriptions.

\section{Povzetek}

Velik del vojaških napisov se nahaja na nagrobnikih (nagrobne plošče, stele, sarkofagi, pepelnice, grobnice in žare) (glej graf I in 2), v manjšem številu pa na votivnih napisih (v obliki oltarjev in posvetil). Vojaki na napisih nastopajo kot pokojniki, pa tudi kot postavljavci napisov družinskim članom (št. 5, II, I8/19, IO6 in II3). Kot postavljavci spomenikov so vojaki izpričani tudi na napisih št. 2I, 27, 44, 45, 49, 98/104, IOI in II9, katere so naročili še v času svojega življenja in jih oporočno dali postaviti $\mathrm{v}$ spomin sebi in svojim bližnjim. Iz vsega, kar smo navedli, je razvidno, da kljub skromnemu številu obstoječih in dokumentiranih vojaških napisov najdenih širom Slovenije, ti podpirajo predpostavko o prisotnosti rimskih vojakov na obravnavanem območju. Povečano število napisov vojakov iz I. in 2. st. (glej sl. 5) lahko povežemo z intenzivno širitvijo rimske države na jugovzhodni evropski prostor in naprej na Balkan in kasnejšim vojnim dogajanjem znotraj cesarstva.

$\mathrm{Na}$ obravnavanih vojaških napisih Emone, Petovione, Nevioduna, Prateorija Latobikov, Celeje in drugih posamičnih lokacijah po Sloveniji so izpričani predvsem beneficiariji, legionarji, pretorijanci, centurioni in veterani; v treh primerih (št. 48,55 in II $)$ je pri veteranih ome- 
njena tudi funkcija in oddelek vojaških enot v katerih so službovali.

Poleg petnajste Apolonove, osme Avgustove, trinajste Dvojne, druge Italske legije ter posamičnih enot devete Hispanske in štirinajste Dvojne legije, so na vojaških napisih izpričane še prva Pomožna, četrta Flavia srečna, peta Makedonska, šesta Železna, deseta Dvojna, dvanajsta Bliskovita in trinajsta Dvojna legija.

Med pretorijanskimi četami se Druga pretorijanska kohorta pojavi dvakrat, Prva pretorijanska kohorta in Sedma pretorijanska konjenica pa enkrat. Poleg pretorijanskih čet se v enem primeru (št. 98) pojavi tudi poveljnik izvidniške enote pretorijancev. Med pomožnimi četami se prva ala Komagenov in druga ala Tračanov pojavita dvakrat, po enkrat pa prva germanska in prva hispanska kohorta ter druga ala Asturov.

Primeri vojaških napisov iz Emone v I. st. n. št. (glej sl. 6 in 7) dokazujejo zgolj to, da sta petnajsta Apolonova in osma Avgustova legija sodelovali pri osvajanju jugovzhodno alpskega in zahodno balkanskega prostora $\mathrm{v}$ boju proti avtohtonemu prebivalstvu. Podobno ugotovitev lahko razberemo tudi iz vojaških napisov iz Petovione, med katerimi po številu prevladujejo napisi osme Avgustove legije (glej sl. 6 in 7), ki je v okolici današnjega Ptuja postavila vojaški tabor. Iz druge polovice i. st. n. št. so na napisih največkrat izpričani predstavniki trinajste Dvojne legije (glej sl. 7). Njihova omemba predstavlja dodaten dokaz o prisotnosti in nastanitvi trinajste Dvojne legije na lokaciji, ki jo v antičnih virih omenja Tacit $\mathrm{v}$ povezavi z letom štirih cesarjev.

Iz stališča preučevanja rimskih vojaških napisov, sta pomembna tudi Neviodunum in Pretorij Latobikov, kjer številčno prevladujejo beneficiarski napisi (glej sl. 4), ki so v večini primerov oltarji ali posvetila namenjena božanstvom. Največkrat so napisi posvečeni Jupitru in lokalnim zavetnikom kraja. Na napisih št. 3 in 58 je Jupiter poimenovan kot Jupiter Dolihenski. Dolihenov kult je bil po imperiju razširjen posebej med vojaštvom v 2. in 3. st. V Panoniji je doživel razcvet v času dinastije Severov. Na nekaterih primerih so napisi posvečeni posameznim boginjam (št. 4, 17, 33 in 35) ali vsem bogovom (št. 58 in 59) in v enem primeru tudi rojakom (št. 46). Večina votivnih napisov je natančno datiranih (št. 57, 58, 59, 60, 6I, $62,63,64$ in 66). Največ beneficiarskih napisov je datiranih v čas 2. in 3. st., kar dokazuje, da so bili v tem obdobju $\mathrm{v}$ provincialnih mestih ustanovljeni pomembni uradi in druge institucije, ki so jih morda upravljali beneficiariji. Med te iz našega območja nedvomno prištevamo beneficiarsko postajo Pretorija Latobikov. Nobeden od posvetiteljev votivnih napisov ni bil navaden vojak: Valerij Emiljan (št. 3) je bil nosilec znaka, Vibij (št. 4) je bil intendant, Marcijial (št. 17) in Lukij Septimij Tertin (št. IO5) sta bila centuriona, Gaj Kasij Silvester (št. 33) je bil veteran, Publij Maskimij Matern (št. 46) je bil merilec, ostali (št. 35, 36, 37, 38, 39, 40, 4I, 42, 43, 44, 45, 50, 51, 52, 53, 54, $55,56,57,58,59,60,61,62,63,64,65,66$ in 67) pa so bili beneficiariji.

Najdišča vojaških napisov z območja slovenskega prostora so znana tudi na posamičnih lokacijah po Dolenjski in Beli Krajini (npr. v Tržiščcu, Šmihelu pri Žužemberku in Velikemu Korinju pri Žužemberku) ter štajerskega prostora (npr. Črešnjevec, Slovenj Gradec, Slovenske Konjice, Hudinja pri Vitanju in Vrba pri Dobrni), iz česar lahko sklepamo, da so bili ti kraji vključeni v širše zaledje provincialnih mest Celeje, Petovione in Nevioduna. Na skrajnem zahodu Slovenije, na robu naselbine Grad pri Reki, je bilo odkrito in raziskano grobišče s I 49 grobovi. Med temi se je nahajal tudi vojaški nagrobnik vojaka petnajste legije (št. I2O), datiran med l. 53 in 31 pr. n. št. Opaziti je mogoče tudi pričakovane razlike med mesti, ki so vidne že v številu vojaških napisov.

\section{Literatura}

Cassius Dio. Rhomaike Historiae. Translated by Earnest Cary. Cambridge, Meassachusests: Harvard University Press, 1927, http://penelope.uchicago.edu/Thayer/E/Roman/ Texts/Cassius_Dio/home.html (23. januar 2014).

Ciglenečki, Slavko. ',Strukturiranost poznorimske poselitve Slovenije = Strukturierung spätantiker Besiedlung Sloweniens“, Arbeološki vestnik 48 (1997): 191-202.

Gaspari, Andrej. »Apud horridas gentis ...« začetki rimskega mesta Colonia Iulia Emona $=$ beginnings of the Roman town of Colonia Iulia Emona. Ljubljana: muzej in galerije mesta Ljubljane, 2010.

Gilliver, Kate. 'The Augustan Reform and Structure of the Imperial Army." In $A$ Companion to the Roman Army, ur. Paul Erd- 
kamp, I83-200. Chichester: Willy-Blackwell, 2007.

Horvat, Jana. ,'Roman Provincial Archaeology in Slovenia Following the Year 1965: Settlement and Small Finds", Arheoloski vestnik 50 (1999): 215-257.

Jevremov, Blagoj. Vodnik po lapidariju. Ptuj: Pokrajinski muzej, 1988.

Lazar, Irena. ,Celeia.“'In Situla, Volume 4o: The autonomous towns of Noricum and Pannonia / Die autonomen Städte in Noricum und Pannonien, vol. I: Noricum, ur. Marjeta Šašel Kos, Peter Scherrer, 7I-Ior. Ljubljana: Narodni muzej Slovenije, 2002.

Lovenjak, Milan. Situla, Volume 37: Neviodunum - Inscriptiones Latinae Slovenia (ILSL) I. Ljubljana: Narodni muzej Slovenije, 1998.

Mikl Curk, Iva, Ciglenečki, Slavko, Vuga, Davorin. Po poteh rimskih vojakov $v$ Sloveniji. Ljubljana: Zavod Republike Slovenije za varstvo naravne in kulturne dediščine Slovenije, 1993.

Saria, Balduin., Vojaški nagrobni napis iz Emone." Kronika slovenskih mest 3, no. I (1937): 46-48.

Svoljšak, Drago and Žbona-Trkman, Beatrice. 1986. 'Novi napisi v Posočju.“ Arheološki vestnik $37,385-398$.

Šašel, Jaroslav. ,'Avgust 69: vojaški puč v Poetovioni." Kronika I, no. 27 (1979): I-7.

Šašel, Jaroslav. 'Dolihenov tempelj, zgrajen v Pretoriju Latobicorum leta 196." Kronika I, no. 30 (1982): 191-193.

Šašel, Jaroslav. ',Zur Frühgeschichte der XV. Legion und zur Nordostgrenze der Cisalpina zur Zeit Caesars“, Situla, Volume 3o: Opera selecta (1992): 469-477.

Šašel, Jaroslav. 'Pro Legato“. Situla, Volume 30 : Opera selecta (I992): 305-315.

Šašel Kos, Marjeta. Zgodovinska podoba prostora med Akvilejo, Jadranom in Sirmijem pri Kasiju Dionu in Herodijanu. Ljubljana, Slovenska akademija znanosti in umetnosti, 1986.
Šašel Kos, Marjeta. 'The isth Legion at Emona - Some thoughts." Zeitschrift für Papyrologie und Epigrafik 109 (1995): 227-244.

Šašel Kos, Marjeta. 'Je bila Emona nekdanji tabor I5. legije in veteranska kolonija?" $Z g o-$ dovinski ćasopis 52, no. 3 (112) (1998): 317329.

Šašel Kos, Marjeta. 'Cestni postaji Atrans in Pretorij Latobikov" In Zakladi tisočletij Zgodovina Slovenije od neandertalcev do Slovanov, ur. Bronislava Aubelj, 238-240. Ljubljana: založba Modrijan, 1999.

Šašel Kos, Marjeta. Lapidarij Narodnega muzeja Slovenije - Rimski spomeniki - Vodnik. Ljubljana: Narodni muzej Slovenije, 2004.

Šašel Kos, Marjeta. Situla, Volume 43: Appian and Illyricum. Ljubljana: Narodni muzej Slovenije, 2005.

Šašel Kos, Marjeta. Rimsko osvajanje zahodnega Balkana: Ilirik v Apijanovi Ilirski zgodovini. Ljubljana: Zveza zgodovinskih društev Slovenije, 2010.

Šašel Kos, Marjeta. 20I2. ,Colonia Iulia Emona - the genesis of the Roman city," Arheološki vestnik 63 (2012): 79-104.

Tacitus. Annales - Ab excessu divi Augusti. Translated By Fran Bradač. Maribor: založba Obzorja, 1968.

Visočnik, Julijana. 2008. ,Vojaški napisi iz Celeje in njene okolice." Arheološki vestnik 59 (2008): 325-357. 
-

r

$\downarrow$

G

1

-

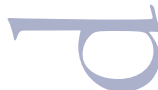

( )

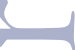

(U)

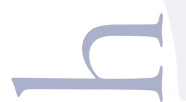




\title{
How to address Hyperobjects in exhibitions using emerging technologies
}

\author{
Nils Wiberg
}

This paper will show some ways in which the interaction can harmonize with the interpretation and the topic at hand. But it will also tackle the new forms of understanding and interpretation that have emerged in recent years and how they can be translated in to interaction. It outlines the addition of another $\mathrm{O}$ in the discourse: the operative one. Using examples of implementations it shows that together can make palpable these new findings and perspectives to visitors of exhibitions in general and their interpretation of Land in particular.

Keywords: Speculative Realism, Object Oriented Ontology, Philosophy, Exhibition Design, Interpretive Planning, Land Use Interpretation, Emerging Technologies, New Interfaces

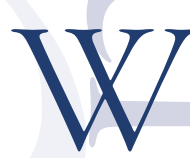

hen designing the interaction for cultural heritage, or any other museal experience it is optimal that before one spatializes the interpretation and divides topics to find an underlying interactive metaphor that holds for the entire experience. That is to say in the same way as the visual aesthetic must go hand in hand with the topic at hand, so must the integration aesthetic.

\section{Explanandum}

For example when we were designing an installation for the sea monster museum in Bíldudalur in the north of Iceland, it was important to tailor the interaction to the complete narrative of the museum. The concept of it was to tell the story of the cryptozoological past of the past of the Icelandic west fjords in a Harry-potteresque kind of time capsules research center for the study of sea monsters. It ought to appear to have been frozen in time at the turn of the 2 oth century and now rediscovered and exhibited as such. The narrative then took place on a sort of meta-level of anthropology.

To place a futuristic or even modern interface in such a context would appear highly anachronistic so what we instead did was to adapt the interaction aesthetic to the mechanistic ideals of the time and just augment those interactions with the power of pixels. When the physical nature of the wheels that moves the map creates a natural form of momentum scrolling that, par-

I Nils Wiberg, Use Qualities: An Organic Luxury We Can Afford. A Primer and Implementation of how Organic Interfaces can Improve the Use Quality Affordance (Umeå: Umeå University, 2009).

2 The results can be seen at http://gagarin.is/work/sea_monster_table. (2016-02-01). 
ticularly map, interfaces otherwise try to mimic in a kind skeuomorphism of interaction, the pretention of physicality. Physical pucks were chosen as the interactive elements for the table top rather than a touch screen interface, with to retain the physical, tangible aesthetic and to so to speak, to outsource complexity to the physical world. Two pucks can for example not be at the sample place at the same time thus the social interaction of people solves any potential problem of two people competing for the same content. A similar solution as we have seen in our different interactions of a Wheel of Time. ${ }^{3}$

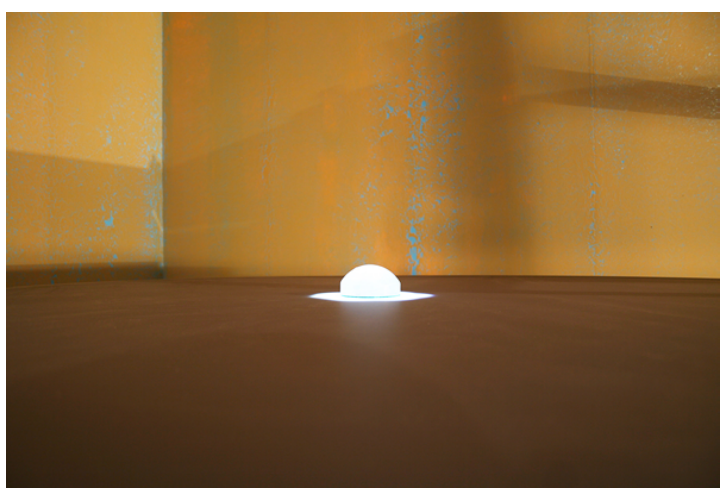

Similarly when we were asked to explain the concepts surrounding electricity in an exhibitory form we chose the starting point of the power within people. With a first installation consorting of a semi transparent concrete wall visitors were asked to exude pressure on the wall which had a large screen embedded in it. The visual result communicated, or primed, this as the informing metaphor ${ }^{4}$ of the exhibition. Now it was easy to further explain the other forms of energy through the exertion of power in the visitor translated in the different kinds and translations of power, work, energy and electricity. Then the visitor is free to move, lift and pump the information out of the exhibits. ${ }^{5}$

In creating a metaphor for the recent exhibition for the town in the Westman islands

https://vimeo.com/153748339 (2016-02-o1).

4 Lakoff, George and Mark Johnson, Metaphors We Live By (Chicago: University of Chicago Press, 1980).

5 Gagarin, "Powering the Future", http://gagarin.is/work/powering_the_future (2016-02-0I)

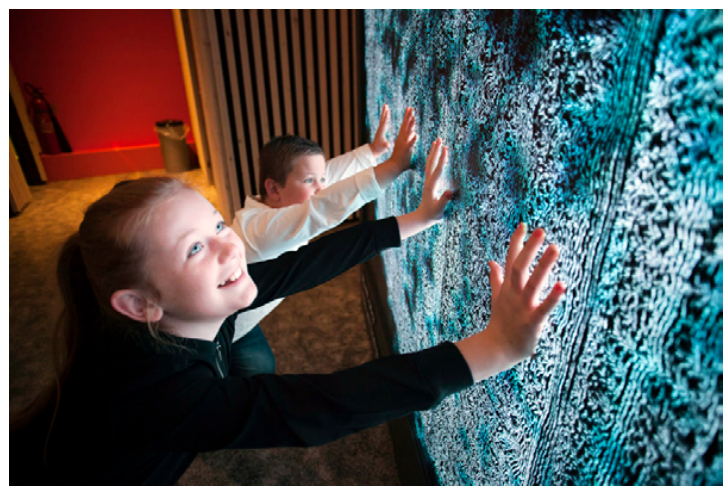

of Iceland that suffered a volcano eruption we choose to use again physical metaphors but here ones where the users act as first responders and excavators, using the camera to search in houses too dangerous to enter, pushing together the ruined houses to see them in their original condition and fittingly an interactive sandbox where visitors dig in actual sand from volcano ash to reveal digital content about the things hidden under the lava in this Pompeii Of the North.

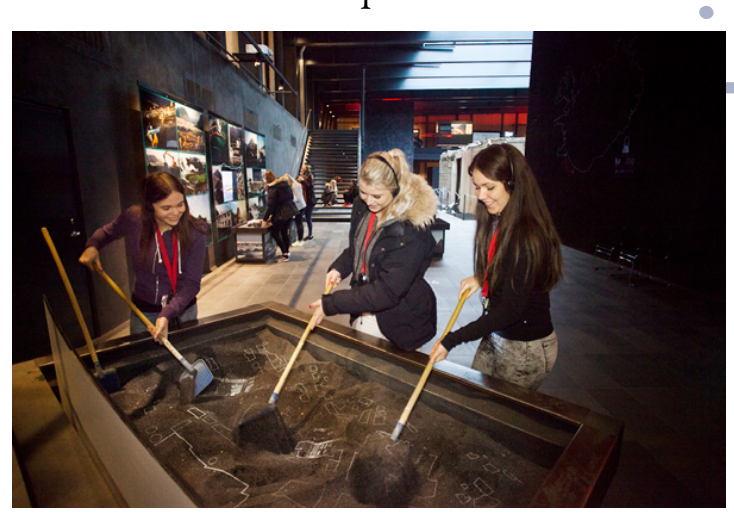

When creating these metaphors the aesthetic integrity of the interaction is completely integral to the outcome. Retaining the visitor's belief in the interaction is what keeps estrangement at bay and focuses on the story you want to tell. This is why quality is important. The appearance of latency etc. has to be without failure. It's a magic trick and magic tricks don't work if you make MOST of the bunny rabbit disappear, all your left with then are crying children.

6 Gagarin, „Eldhemar“, http://gagarin.is/work/eldheimar (2015-02oI). 
This for example was very important when creating the interaction for our National Park Explorer ${ }^{7}$ in a national park in Breheimen Norway. Here the feedback of the physical interaction was not on the object itself but rather on the map all user interact with, therefore we were unable to make latency a playability feature, which we had previously done in the aforementioned sea monster table, where the latency was incorporated as a use quality contributing to the lurking feeling of vulnerability we wanted the visitors to experience. Since the control function and the feedback were separated in the National Park Explorer however the latency had to be kept at a minimum to keep the mental pairing of the input and the feedback intact.

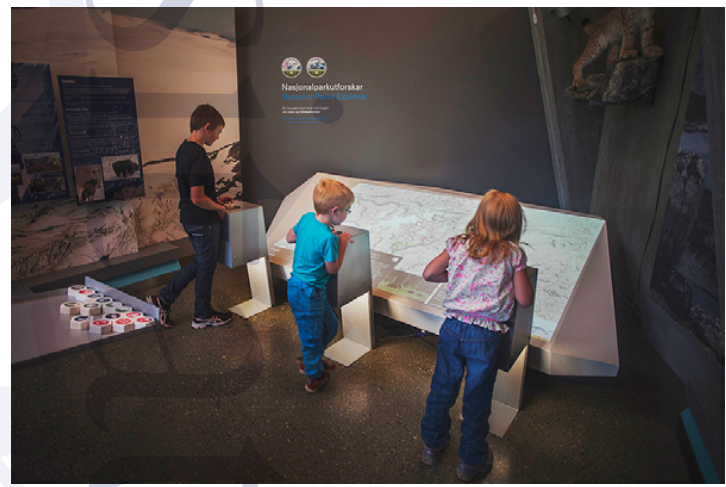

Based on these example we see that it is completely possible to incorporate the interaction as a part of the interpretation and interaction. However in a few of our upcoming projects there is a new class of issues more and more prevalent in museums that require a new class of interactive approaches.

\section{Theoretical background}

In recent times some headway in the philosophical approach of the most pressing issues of our time have been made. Due to a philosophical standstill over the last roo years, few scientists, artists or designers have looked to philosophy to find answers or even questions. The ones who did oftentimes found themselves in a Heideggerian maze of circular arguments. The problem

Vimeo, https://vimeo.com/72203926 (20016-02-OI). philosophy faced was that of not finding enough terra firma to stand on in order to basically say anything about reality itself. There has been, since Kant, and some unfortunate misinterpretations of Nietzsche, a tending towards an ontological detente where philosophy narrowed its foci of attention. The latter rendered a total value relative argumentation and the former a epistemological recursion. To paraphrase, it could go something like: How can I know that there are (or are not) real things? What gives me (or denies me) access to those real things? What are the possibilities of this access? What is the possibility of possibility? The Kantian rift had become a chasm deep enough to fill almost all of continental philosophy. This correlationism ${ }^{8}$ is not providing answers, or questions, that move or benefit other sciences, art forms or practices. Some philosophers understandably had enough of this and thought about the current issues facing humanity, e.g. technological singularity; machine-human mergers or global warming.'

\section{Background}

The shortcomings of the academic paper mill might be to blame here. These thoughts have predictably not evolved through the academic circuit as intended, but instead been circulating on forums on the internets where people within academia who have been frustrated with the existing forms of academic output and its incapability to accommodate new, unfinished, thoughts or work in progress.

The discourse has sort of ventured all the way into a place where one has been forced to ask oneself: Why save a species if one does not believe in a species. Particularly this needs to have an operational level as well. That something can be done even though we do not agree on holistic definitions or hierarchies or what privileges whom.

Of all the things humans have created, releasing the hyper object of climate change will

8 Levi Bryant, Nick Srnicek and Graham Harman, ed.The speculative turn (Melbourne, [Victoria] Australia: re.press, 201 I).

9 Timothy Morton, Hyperobjects: Philosophy and Ecology after the End of the World (Minneapolis: University of Minnesota Press, 2013). 
probably be our last legacy. A battle for humanity's remaining legacy will exist between the pyramids of Giza and the traces of the 1986 Chernobyl disaster from which newly born lichen of the Norwegian highlands in the autumn of its life span will still contain traces of cesium.

Culture as such could maybe be counted from the cave paintings and onwards. When looking at the oldest paintings from about 30 ○o years ago and extrapolated equally far into the future, maybe the only trace of humanity would be its vain attempts of terraforming and contribution to climate change. If we were to stop releasing carbon now, $25 \%$ of it will still be in affect 30000 years out.

There is however within the fields of speculative realism and object oriented ontology a movement towards dealing with this problem. A realization has been reached by continental philosophers; beyond internal debates of monism/ dualism etc; that intellectual headway need making. And a strategy for how said headway can be made has been laid out.

\section{0}

In classic style of continental philosophy however there seems to be lacking a niveau of implementation to this theoretical strategy. Lets call it a tactical or operative level. This is where this paper is suggesting a number of very specific examples of how such implementation can be done. In terms of how the implementation is intended it is a kind of operationalization of speculative realist thought and object oriented ontological classes. So what then would be the outcome? It could be actual things that occupy the world in a more non-deceptive way. Cellphones that contain visual or aesthetic traces from the nickel mines that make them possible. It could be sneakers whose transparency reflect not its technical material qualities but instead the burdens of the underlying working conditions that are its prerequisites. A moral transparency rather then a material one so to speak.

However one would also have to go further in order to fully allow for these ideas to be able to be instituted in objects. They should not only be result on ontological levels of say consumer products but also on an epistemological level. This thus brings us to the didactic tools which are used to create knowledge. These have evolved tremendously in recent years and become much more participatory, interactive and containing certain feedback loops and distribution of power (Wikipedia comes to mind). But they, the tools of learning, are in practice quite opaque in this sense. They require a lot from an informed user and do not, as of yet, in any aestethic or visual way communicate their bias. Lets take for example a geographical information system. It has a lot of embedded value based or political choices; however these are not immediately visual to the user.

\section{OOOOI}

As an object of examination a few implementations on an operative level will show the attempts to try and enable a polysemy of sorts in term of how the design and interpretation of geography/ geology and land can be designed.

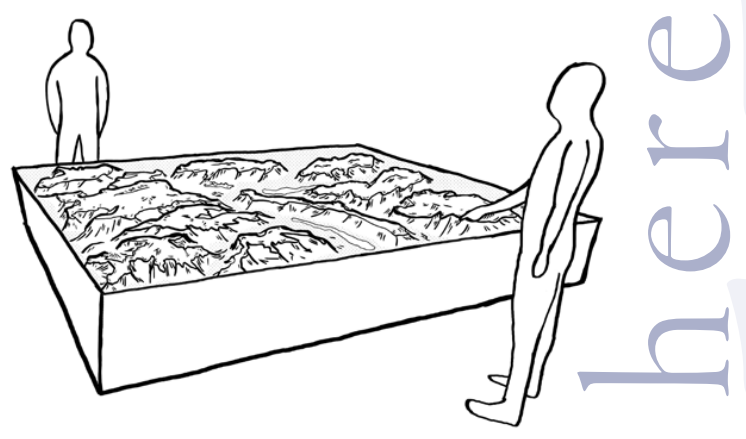

The design objects we firstly use as examples is a $3 \mathrm{~d}$ map interface that contains two viewing perspectives, each from different floor levels and with different interactions but both using the same object (map) as feedback. This dual view would afford on the one hand a utilitarian perspective on what this land can be used for, in a tourist way rather than a land use interpretation 
way; on the other hand it shows how this land (and its utilities) are being threatened from the second floor.

The effect sought here would be that since the focus of attention remains the same, a map, but the perspectives are different, utility/climate(threat posed to utility), a more broad and differentiated didactic can be achieved. One can

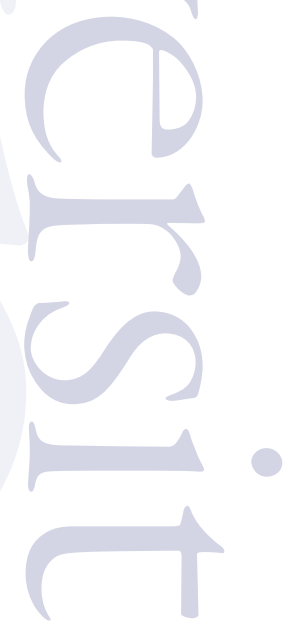

on the one hand inform on what kind of activities that are available and at the same time, from the second level see how those same activities are

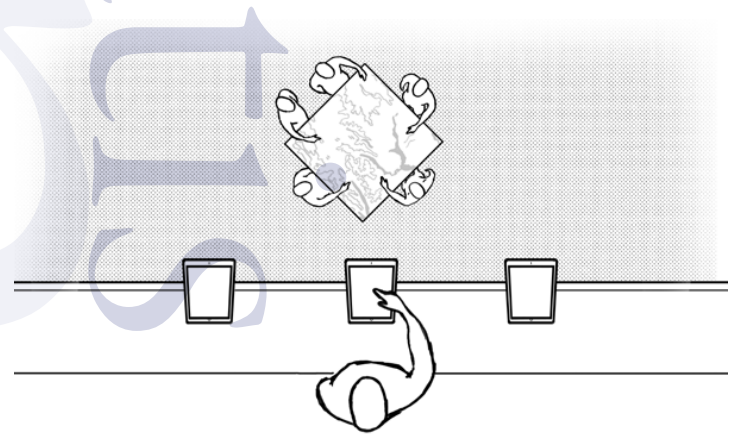

being threatened from a changing climate. For example one can in the first level get to examine where there are summer houses for rent and then on the second level see how those summer house are under threat from rising sea levels. These two levels then work in tandem, they only have meaning in tandem and are dramaturgical contingent on each other. One might be of the per- suasion that the latter perspective is somehow "truer" and the first one more real but these are both needed to complete, an albeit incomplete picture. One doesn't know what is being threatened without the utility and one doesn't know what is the threat without the zoomed out climatological view.

In a third installation the Land Interpreta-

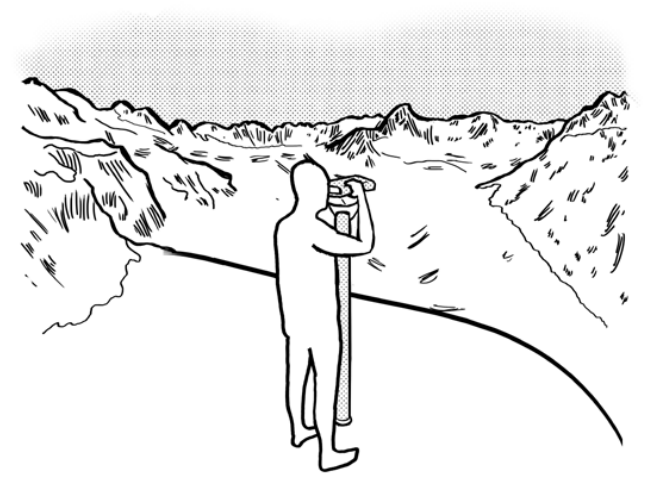

tion becomes very vivid and palpable: with the use of augmented reality binoculars one can create layers of information put on top of existing landscape in real time. As a result the geological time perspective can be viewed in a sped up manner. For example the creation of a fjord as a result of the interaction of a glacier and a mounted can be visualized in ${ }_{3} \mathrm{D}$ and shown as an animation on top of existing vistas. But also the extrapolation in climatology can be brought to this visual medium to show glaciers receding, tree line climbing and water levels rising. All in the very real and tangible way all of the science say is necessary to get people to not only think on the geological scale but also feel on the geological scale.

These implementations can more accurately represent, in a compelling interaction and participatory way these new hyper objects. The dual (or plural) layers of objects can be reveal through user interactions from different points of view. Imagine for example a deictic interaction that takes in to account the point of view from which the spectator is pointing to reveal the content 
information interactively from specifically that point of view. These kinds of interactive and participatory way of content dissemination has totally new possibilities to cater to the more complex issues of our time.

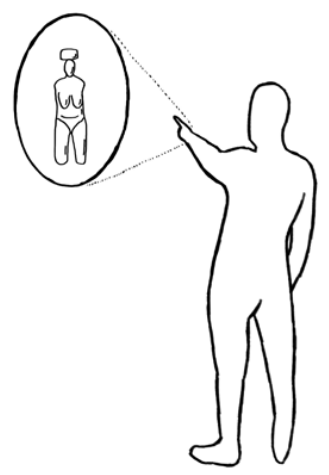

\section{Povzetek}

Pri oblikovanju in pripravi interpretativnega načrta za interaktivne razstave je pomembno razmišljati o tem, katere interaktivne metafore uporabiti. Če namreč interaktivnost ni pravilno uporabljena, lahko ovira razumevanje interpretacije namesto da ga podpira. Članek je pokazal nekaj načinov, s katerimi se lahko interakcijo uskladi z interpretacijo teme, poleg tega pa se je dotaknil tudi novih oblik razumevanja in razlage, ki so se pojavile v zadnjih letih in kako jih je mogoče prevesti v interakcijo. $V$ zadnjih letih sta špekulativni realizem in objektno usmerjena ontologija ustvarila take paradigme v filozofiji, da so skušale opusti idealistični razkol ter omogočiti, da se ukvarjajo s perečimi vprašanji v današnjem času. Ta dokument opisuje dodajanje drugega O-ja v diskurzu, in sicer tistega operativnega. $Z$ uporabo primerov implementacije se dokazuje te nove ugotovitve in možnosti za obiskovalce razstav na splošno in njihovo interpretacijo dežele še posebej. Rezultat cilja predvsem k temu, da se omogoči premike žarišč, hkrati pa ohranja predmet pozornosti za muzejske obiskovalce.

\section{Summary}

When designing and doing interpretive planning for interactive exhibitions it is important to think of what interactive metaphors to employ. If not used correctly the interactivity can impede understanding of the interpretation instead of supporting it. This paper has shown some ways in which the interaction can harmonize with the interpretation and the topic at hand. But it has also tackled the new forms of understanding and interpretation that have emerged in recent years and how they can be translated in to interaction. In recent years speculative realism and object oriented ontology have created a paradigm shift of sorts in philosophy in order to leave behind the idealist rift and enable it to deal with the pressing issues of our modern times. This paper outlines the addition of another $\mathrm{O}$ in the discourse: the operative one. Using examples of implementations that together can make palpable these new findings and perspectives to visitors of exhibitions in general and their interpretation of Land in particular. The resulting designs aim to enable shifts of foci whilst retaining the object of attention for the museum visitor.

\section{References}

Lakoff George and Mark Johnson, Metaphors We Live By (Chicago:University of Chicago Press, 1980).

Bryant Levi, Nick Srnicek and Graham Harman, ed.The speculative turn (Melbourne, [Victoria] Australia: re.press, 2011).

Morton, Timothy, Hyperobjects: Philosophy and Ecology after the End of the World (Minnesota: University of Minnesota Press, 2013).

Nils Wiberg, Use Qualities: An Organic Luxury We Can Afford. A Primer and Implementation of how Organic Interfaces can Improve the Use Quality Affordance (Umeå: Umeå University, 2009).

Gagarin, "Eldheimar" http://gagarin.is/work/ eldheimar (2015-02-OI).

Gagarin, "Sea Monster", http://gagarin.is/ work/sea_monster_table (2015-02-OI).

Vimeo(a), https://vimeo.com/153748339 (2015O2-OI).

Vimeo(b), https://vimeo.com/72203926 (2015O2-OI).

\title{
(T)
}

1

$\checkmark$

$d$

$-$

O

\section{(}

(1)

\section{A}




\title{
Onomastical analysis of inscriptions from Koper and its vicinty
}

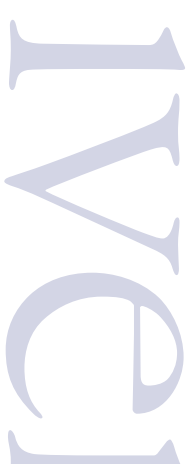

\author{
Vladimir Kusik
}

The article gives an onomastical analysis of twenty-four inscritpions found in or in the vicinity of Koper, all of which are already published in the relevant corpora of Latin texts. Origin of the people mentioned in the inscriptions include indigenous population romanized to certain extent, orientals, westerners and immigrants from other parts of Italy. All inscriptions are dated to the period of the Principate.

Keywords: Aegida, Koper, onomastics, romanization,epigraphy
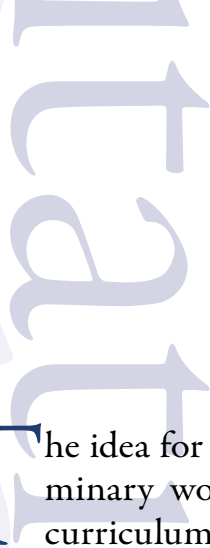

$\mathrm{T}$

he idea for this article originated as a seminary work which was a part of the curriculum during the authors stay at the University of Primorska within the student exchange programme. As the scope of the work grew, Dr. Gregor Pobežin suggested and provided professional guidance to further analyze the names of the inhabitants of Aegida (todays Koper) mentioned on the inscriptions found in Koper and its vicinity.

All the monuments are already published ${ }^{2}$ and although it has been written about the po-

An article about the names found in Volčji Grad served as a starting point for this work, see Gregor Pobežin, "Nagrobnik s cerkve sv. Janeza Krstnika na Volčjem Gradu (CIL V 712) ", in Volčji grad, ed. Mitja Guštin (Komen: Občina Komen, 2012), 59-67.

2 Attilio Degrassi, Inscriptiones Italiae, Vol. X., Regio X, Fasc. IIIHistria septentrionalis (Roma: La libreria dello Stato, 1936).

pulation of Aegida in antiquity, ${ }^{3}$ an onomastical analysis of each monument can further contribute to the knowledge of this subject. Throught it, not only the origin and the frequency of the name in the Empire is given, but also the social, legal and in some rare cases geographical information about the inhabitants of Aegida. Each momunent analyzed in the article is presented with the nature of its finding, the information of its whereabouts and the place of keeping. The inscriptions are translated, each part of the name of the person mentioned is analyzed and all available information that can be discerned is presented. The monuments are dated on the basis

Attilio Degrassi, Abitati Preistorici E Romani Nell'agro Di Capodistria E Il Sito Dell'antica Egida, (Parenzo: G. Coana \& Figli, 1933); Alka Starac, "Pitanje istočne granice Cisalpinske Galije i odnos općina Tergeste i Egida”, Histria Archaeologica 24-25 (1993-1994): $5-57$.

DOI: HTTPS://DOI.ORG/I0.26493/2350-5443.3(2)69-98 
of epigraphical features if possible and crossreferrencing with the entries in the relevant databases.

\section{Short history of Aegida and its epigraphical monuments}

The city of Koper in the Slovenian part of Istria is situated on the coast and a small island south of the Rižane river. Today, the island is the place where the historical center of Koper stands. In antiquity, it was location where the Roman town of Aegida was built. ${ }^{4}$

First mention of Aegida in the historical sources is found in Elder Plinys Naturalis Historia. ${ }^{5}$ The name Aegida is a Greek word for a goat, as is Capris, a later Latin name of the settlement which was used from the 7 th century AD. It is possible that both the Greek and Latin names of the town are the direct translation of a native word for goat. Other names included in the sources, maps and itiniraries are: Iustinopolis, Caprae, Capris, Insula Caprea or Capritana insula, so it is not surprising that the modern Slovenian name for Koper can be derived from its Latin root. ${ }^{6}$

The settlement on the Koper island was built probably in the beginning of $\mathrm{I}^{\text {st }}$ century $\mathrm{BC}$ and during the next hundred years, Aegida acquired characteristics of an urbanized Roman town. Accoridng to Pliny, at the latest from the time of Augustus Aegida was oppidum civium Romanorum, which can be considered that it held the rank of municipium. ${ }^{7}$ With the constitution of a municipium, Aegida was enrolled in the voting disctrict of the tribe Pupinia, same as nearby Tergeste. In I8 - I2 BC the area from Rižane (Formio) up to Raša (Arsia) river was incoporated into Italy. After the initial growth and

4 Radovan Cunja, "Koper, Kapucinski vrt", Arheološki pregled (1986) 1987:118-120; Matej Župančičc, "Sermin ob Rižani, pretres virov in arheoloskih podatkov", Arheološki vestnik 36 (1985): 315-325; Matej Župančič, "Inter utrumque tuta" in Koper zwishen Rom und Venedig, ed. Matej Župančič (Koper: Regionalmuseum Koper, 1991) 6-II.

$\mathrm{HN}_{3 .} \mathrm{I} 29$

6 Rav. Ann. 4. 31, 5.14; Jaroslav Šašel, "Koper”, Arheološki vestnik 25 , (1976): 446-460.

7 Mate Suić, Anticki Grad Na Istocnom Jadranu (Zagreb: Sveučilišna naklada Liber, 1976), 34 . development into an urban settlement, it seems that from the time of Pliny to late antiquity, Aegida lost its importance. It is not mentioned in the itineraries, maps or historical sources. It is possible that this absence from is related to its reduced traffic importance and not with its loss of self-governing status. The fact that Aegida was not granted the rank of colony is further proof that the town experienced a period of slowed growth in every sense. $^{8}$

Roman inscriptions found in Koper are quite numerous, considering the size and importance of the town. However, the nature of their finding poses a significant problem in interpeting them and using the information for reconstructing the history of Aegida. They were not found in the archaeologically relevant context and due to renaissance and humanistic tendecies of collecting Roman monuments in private collections, the information about their true origin is practically unknown. Authors have pointed out that there is no proof that any of the monuments from Koper or its vicinity were found on the island itself, where ancient Aegida stood.'

The history of the monuments, comprised mostly by Mommsen and Kandler who tracked and transcribed them, later to be published by Degrassi in Inscriptiones Italiae for Regio $X$, reveals that majority of them were found built in public buildings of Koper, e. g. Episcopal palace, city walls, cathedral, other churches, curia or laying in the main city square (Loggia). Some were found in the gardens of monasteries or transferred from nearby villages to the estates of the noblemen, while others were lost in the process, so only drawings exist. After Mommsen and Kandler wrote down the inscriptions, most of them were taken to the atrium of gymnasium and after I9II in the Museum of Koper, where they today stand inserted in the wall.

\footnotetext{
Alka Starac, "Pitanje istočne granice Cisalpinske Galije i odnos općina Tergeste i Egida", Histria Archaeologica 24-25 (1993-1994), 24-29.

Degrassi, Abitati Preistorici E Romani, 798; Šašel, “Koper”, 446.
} 


\section{Onomastical analysis of the inscriptions}

\section{Votive inscription dedicated to Isis}

This monument (Inscr. It. X. 3. I; CIL V 484) is a votive ara, made in Aurisina limestone (height: 0,96 m, width: $0,33 \mathrm{~m}$, thickness: $0,34 \mathrm{~m}$ ). The inscription is found within a rectangular inscription field, which is framed by a triple moulded belt on the front and the right side. The part of the upper frame was cut off. The ara was found in the episcopal palace and is now kept in the Museo Lapidario Maffeiano in Verona. The inscription reads:

\section{Isidi \\ sacrum \\ exmonit(u) \\ eius d(ono) d(edit) \\ L(ucius) Valerius \\ Memor \\ VI vir Augustalis \\ l(ocus) d(atus) p(ublice) \\ "Dedicated to Isis upon her ad monition, as a gift by Lucius Valerius Memor, member of a board of six priests of Augustus, place given by the comminunity}

This is a monument dedicated to the Egyptian goddess Isis by Lucius Valerius Memor, who also served as a priest of Augustus.

Tria nomina formula in which the name of the deceased is written is a sign that he had Roman citizenship.

Praenomen Lucius is one of the most common Roman names.

Nomen gentile Valerius is also very common and found all over the Empire. ${ }^{I I}$ The name comes

According to C. Tititus Probus in his De praenomibus 3.I., Varo thought that there were about thirty praenomina, but already during the Late Republican and Early Imperial times, only seventeen were used. These were: A(ulus); Ap(pius); C(aius); $\mathrm{Cn}$ (aeus); D(ecimus); L(ucius); M(arcus); Man(ius); N(umerius); P(ublius); Q(uintus); Ser-vius); Sex(tius); Sp(urius); Tib(erius); T(itus); V(ibius). Matijašić also adds K(aeso) to this list (Robert Matijašić, Uvod u latinsku epigrafiju (Pula: Filozofski fakultet u Puli, 2002), 59).

II Andras Mócsy, Nomenclator provinciarum Europae Latinarum et Galliae Cisalpinae: cum indice inverso (Budapest: Népművelési Propaganda Iroda, 1983), 300; Barnabas Lórincz, Onomasticon provinci- from Latin and was very popular in northern Italy and the East, especially during the late antiquity. It rose to popularity during the Tetrarchy and it is considered to be an imperial gentilitium, related to emperor Diocletian.

Cognomen Memor is less frequent and considered to be of Latin origin. ${ }^{13}$ It is found on total of twenty two inscriptions across the western provinces and Italy. The highest number of inscriptions which mention this name are from Italy, with the provinces Gallia Belgica and Pannonia also having some recordings of this cognomen. The rest of the inscriptions are spread across the other western provinces: Hispania, Gallia Narbonennsis, Dalmatia, Gallia Lugdunensis, Britannia and Moesia Inferior. ${ }^{14}$

Lucius Valerius Memor also recorded that he was a member of an imperial cult and held an office as one of the seviri Augustales. These priests were often freedmen who sought to improve their social status through religious functions. Their duty was to take care of the imperial cult of Augustus, but also of later emperors. They also had an obligation to fund public works, pay summa honoraria or organize games. ${ }^{15}$ This individual was likely a significant benefactor who was honoured after his death by being given a special funerary spot.

Due to his service as a priest of imperial cult and his Roman name, the deceased was almost certainly a freedman whose origin was probably somewhere in the West, where the Romanization has already taken place.

arum Europae Latinarum, vol. IV: QVADRATIA-ZVRES (Wien: Forschunsgesellschaft Wiener Stadtarchäologie, 2002); 143-146.

I2 Bennet Salway, "What's in a Name? A Survey of Roman Onomastic Practice from c. 700 B.C. to A.D. 700 ." Journal of Roman Studies 84 (1994), 124-145.

13 Alföldy, Die Personennamen in der Römischen Provinz Dalmatia, 340.

I4 Iiro Kajanto, The Latin Cognomina: Societas Scientiarum Fennica, Commentationes Humanarum Litterarum, XXXVI 2 (Helsinki, 1965), 255; Mócsy, Nomenclator provinciarum Europae Latinarum et Galliae Cisalpinae, 185; Lörincz, Onomasticon provinciarum Europae Latinarum, vol. IV, $75-76$.

I5 Lawrence J. F. Keppie, Understanding Roman Inscriptions (Baltimore: Johns Hopkins University Press, 1991), 57-58; Lily Ross Taylor, "Augustales, Seviri Augustales, and Seviri: A Chronological Study." Transactions and Proceedings of the American Philological Association (1914), 232. 
Date of this monument is difficult to assert on the basis of epigraphical features. It can be conjectured that the monument was erected in the 2nd century AD as the term seviri Augustalis became the most frequently used. ${ }^{16}$

\section{Votive inscription dedicated to Silvanus}

This monument is a votive inscription dedicated to Silvanus (Inscr. It. X. 3. 2; CIL V 485). It is engraved in a small stone slab, which supposedly stood inserted in the city walls. Mommsen, on the other hand, saw it on a public square (Loggia). Now it cannot be found anymore. The inscription reads:

\section{Silvano

This monument is a votive inscription dedicated to Silvanus, a popular deity of the woods.

The abbreviation at the end of the inscription $(V S L M)$ indicates that it is a monument erected after a successful completion of some kind of business venture, trip or a vow taken earlier. ${ }^{17}$ Altars of this kind are very common across the whole Empire.

The name of the dedicator, Quintus Appuleius Epagathus, is written as tria nomina, which means that the individual had Roman citizenship.

Praenomen Quintus is one of the most common Roman names.

His nomen gentile, Appuleius, originates from gens Appulea, an old Roman plebeian family). ${ }^{18}$ It was very popular in Italy. ${ }^{19}$

16 Ross Taylor, "Augustales, Seviri Augustales, and Seviri: A Chronological Study", 240.

17 Keppie, Understanding Roman Inscriptions, 93.

I8 William Smith, William Wayte, ed., A Dictionary Of Greek and Roman Antiquities (London: John Murray, 1890), 248.

19 Alföldy, Die Personennamen in der Römischen Provinz Dalmatia, 60.
His cognomen, Epagathus, is rather rare and of Greek origin. ${ }^{20}$

It appears on eighteen inscriptions, mostly from Italy and the western provinces like Hispania, ${ }^{21}$ Dalmatia, ${ }^{22}$ Gallia Narbonensis and Moesia Inferior. $^{23}$

Quintus Appuleius Epagathus was most likely a slave, whose name is of oriental, Greek origin. After some time he acquired freedom and citizenship, likely by way of manumission. In this way his praenomen and nomen gentile were inherited from his former master, while he retained his single slave name, Epagathus, as a cognomen. While his origin might have been from the East, a Greek name is not sufficient to make this claim, since slaves were often given Greek names regardless of their origin, especially after the Late Republic and Early Empire periods. ${ }^{24}$ However, since the master bears a true Roman name of Italic origin, it can be pressumed certain Quintus Appuleius was a natural-born citizen, who was maybe a colonist from Italy and owned land in Aegida.

The monument is dated to $\mathrm{I}^{\text {st }}$ and 2 nd cen tury AD.

\section{Funerary monument which mentions an individual of the Pupinia tribe}

This monument (Inscr. It. X. 3. 6; CIL V 487) has a cuboid shape and is made in Aurisina limestone (height: 0,29 m, width: $0,86 \mathrm{~m}$, thickness: 0,12 m). Letters are finely inscribed and deep-cut. It first stood in the wall of Episcopal palace. Mommsen and Kandler saw it built into the floor on the entrance of the local school or nursery while others saw it in the atrium of the gymnasium. Now it is kept in the Museum of Koper. The first line of inscription is lost, but Tomasini and Gravisi transcribed it. The inscription reads:

\footnotetext{
20 Alföldy, Die Personennamen in der Römischen Provinz Dalmatia, 360

2 I Epacathus(!) - CIL II 5527

$22\{$ A\}epacathus (!) - CIL III 3175 b

23 Mócsy, Nomenclator provinciarum Europae Latinarum et Galliae Cisalpinae, 114; Lőrincz, Onomasticon provinciarum Europae Latinarum, vol. II, 118 .

24 Matijašić, Uvod u latinsku epigrafiju, 62.
} 
---]Pup(inia) Forens[is]

[annor] um XXIII

[lec]tus ordine iura[torum sentetia]

"Pupinia of the Forensis, years 23, chosen by the decision of the order of jurors"

This inscription mentions only one person whose name is not fully preserved. Praenomen and nomen gentile are completely missing, but the tribal affiliation, cognomen and age are preserved.

It is certain that Pup(inia) refers to the tribe in which the person was enrolled, as it is one of thirty-five known Roman tribes. ${ }^{25}$ As mentioned in the introduction, citizens of Tergeste were enrolled in the same tribe. Likely, when Aegida was constituted as a municpium, its inhabitants were also assigned to the tribe Pupinia . ${ }^{26}$

Cognomen Forensis is very rare and there is only one other inscription mentioning this surname in the western provinces ${ }^{27}$. Its origin is Latin and the word itself derives from the word for forum so it can be considered a true Roman cognomen. ${ }^{28}$

The last row of the inscription mentions a political function or an appointment. The formula lectus ordine iuratorum sentetia means that this person was elected for some magistracy. Two other inscriptions from Koper (Inscr. It. X. 3. 7.) and Aquileia (CIL V 949) also uses the same formula. There are different views on what this appointment might be related to. One is that this magistracy was a form of a legal advisor in the communities. There is also an argument that the formula itself signifies a different magistracy, that of an advisor to censor who would be elected by the decurions. Lastly, one theory suggests that it might signify a person elected into municpial ordo decurionum during the census. ${ }^{29}$ In any case, it is likely that be-

Keppie, Understanding Roman Inscriptions, I40; Matijasici, Uvod u latinsku epigrafiju, 66.

26 Starac, "Pitanje istočne granice Cisalpinske Galije i odnos općina Tergeste i Egida", 28-29.

27 Foresis-CIL III 1968; Mócsy, Nomenclator provinciarum Europae Latinarum et Galliae Cisalpinae, 129; Lórincz, Onomasticon provinciarum Europae Latinarum, vol. II, 148.

28 Kajanto, The Latin Cognomina, 208; Alföldy, Die Personennamen in der Römischen Provinz Dalmatia, 340 .

29 Degrassi, Abitati Preistorici, 802-803; Alka Starac, "Pitanje istočne granice Cisalpinske Galije i odnos općina Tergeste i Egida”, 26. cause this individual was appointed to some magistratcy, he was a Roman citizen.

Be that as it may, this formula appears only in two other inscriptions in northern Italy and Istria and it is possible that it was used only in a rather short time of period and small geographical area. ${ }^{30}$ The inscription is considered to have been made in the early $\mathrm{s}^{\mathrm{st}}$ century $\mathrm{AD}$.

\section{Funerary monument \\ of Lucius Publicius Syntropus}

This big stone monument was used as a support for the door frame of the doors on the southern entrance of the Koper cathedral (Inscr. It. X. 3. 6; CIL V 488). The monument, together with the doors is situated in the street close to the public square. The monument went missing after 1788 . The inscription reads:

\section{L(ucius) Publicius \\ Syntropus \\ archigallus \\ $v$ (ivus) f(ecit) sibi et \\ [...] \\ $h(o c) m$ (onumentum) $b($ eredem) $n($ on) s(equ- \\ itur) \\ "Lucius Publicius Syntropus, archigallus. made it for himself while still alive. This mo- nument does not follow the heir}

This is a monument of funerary character, erected by Lucius Publicius Syntropus for himself and one other person whose name is not preserved because the fifth row of the inscription is missing.

Tria nomina formula, in which the name is written, is a sign of Roman citizenship.

Praenomen Lucius is one of the most common Roman names.

Nomen gentile, Publicius, is attested very often in the northern Italy, especially in the area around Tergeste, northern Istria and Cisalpine Gaul.

30 Maria S. Rossignano, "I Praefecti iure dicundo nell'Italia settentrionale" in Epigrafia. Actes du colloque international d'épigraphie latine en mémoire de Attilio Degrassi pour le centenaire de sa naissance. Actes de colloque de Rome (27-28 mai 1988) (Rome: École Française de Rome, 1991), 520. 
It was associated with municipal freedmen of oriental or African origin after the Constitutio Antoninana was enacted. ${ }^{3 \mathrm{I}}$ The name originally comes from Latin. ${ }^{32}$

Cognomen Syntropus is considered to be of oriental origin and popular among freedmen. ${ }^{33}$

Lucius Publicius Syntropus also held a function of an archigallus, a high official of the cult of Magna Mater. Galli were priests of the said goddess who originated in Asia Minor during the Hellenistic period. There are conflicting views among authors as to when the institution of archigalli first appeared. Some claim it was during the reign of Claudius, while other put it in the 2 nd century $\mathrm{AD}$, after the reforms of Antoninus Pius. ${ }^{34}$ In the eastern provinces they held some civil magistracies, while in the West their function was reserved for religion and rituals in which they often participated with other priests. Archigalli were mostly present in the cities with the status of colonies, but also in some smaller settlements. ${ }^{35}$ They are mentioned by Pliny (HN. 35. 7.), but most of the information comes from epigraphic sources which number twenty-five inscriptions. They reveal that archigalli were often freedmen of oriental origin. ${ }^{36}$

From the analysis of the inscription, the name and the function mentioned, it can be concluded that Lucius Publicius Syntropus was a freedman. He was likely of oriental or African origin and held a function of archigallus, the priest of the cult of Magna Mater. It is unknown where he performed his function, but Tergeste, where three in-

31 Alföldy, Die Personennamen in der Römischen Provinz Dalmatia, 112; Palma Karkovic Takalic, "Period of Introduction and Role of Archigalli in Context of the Inscription of L. Publicius Syntropus from Koper "Archaeologia Adriatica 6 (2012): 89 and 94 .

32 Alföldy, Die Personennamen in der Römischen Provinz Dalmatia, 337.

33 Alföldy, Die Personennamen in der Römischen Provinz Dalmatia, 304.

34 For the earlier datation see Jacopo Carcopino, Aspect mystiques de la Rome païenne (Paris: L'Artisan du Livre, 1942); for the later datation see J. Beaujeu, La religion romaine à l'époque de l'empire, La politique religieuse des Antonins (96-192) (Paris: Les Belles-Lettres, 1955); P. Lambrechts, R. Bogaert, Asclépios, archigalle pessinontien de Cybèle. Hommages à Marcel Renard, II., Coll. Latomus io2, (1969).

35 Karković Takalić, "Period of Introduction and Role of Archigalli",9698.

36 Karković Takalić, "Period of Introduction and Role of Archigalli", 94. scriptions mentioning Magna Mater were found, ${ }^{3}$ and Aquileia, the great trade port and Regio $X$ capital, are viable candidates.

The monument was dated in the time frame from second half of $\mathrm{I}^{\text {st }}$ century to first half of 2 nd century AD. The date is based on the use of $\mathrm{v}(\mathrm{i}$ vus) $f($ ecit) sibi formula which is often found in wider Trieste area during the second half of $\mathrm{I}^{\text {st }}$ century $\mathrm{AD}$. The lack of $\mathrm{D}$ (is) $\mathrm{M}$ (anibus) abbreviation, which appeared in the middle of the $\mathrm{I}^{\text {st }}$ century $\mathrm{AD}$, and became common from 2 nd century $\mathrm{AD}$ onwards, indicates a bit earlier date, towards the middle of the $\mathrm{I}^{\text {st }}$ century AD. ${ }^{3}$

\section{Public inscription of Sextius Brinniarius Certus}

The monument (Inscr. It. X. 3. 6; CIL V 489) is engraved in the Aurisina limestone slab, without a frame (height: $0,5 \mathrm{I} \mathrm{m}$, width: I,02 $\mathrm{m}$, thickness: $0,14 \mathrm{~m}$ ). It is deformed by four holes drilled in recent time. The letters are finely inscribed and deep-cut. The inscription protruded from a window shaft in the Episcopal palace. Kandler and Mommsen collected it and first put it on the public square. Afterwards, it came to the atrium of the gymnasium; since I9I the slab has been kept in the Museum of Koper. The inscription reads:

Sex(tius) Brinniarius
Certus
voto compospecun[ia]
suaportic(um) fecit lon (gam) p(edes) C
"Sextius Brinniarius Certus, having his wish
fulfilled made this portico too feet long at
his own expense"

(

(

This monument is of public character with an inscription that mentions a benefactor, Sextius Brinniarius Certus, who was wealthy enough to erect a portico with his own funds.

Tria nomina formula in which the name is written, suggests that he had Roman citizenship.

His praenomen, Sextius, is one of the 18 most common Roman names.

\footnotetext{
$37 \quad \mathrm{CILV}_{518}, \mathrm{CILV}_{519}, \mathrm{CILV}_{520}$

38 Karković Takalić, "Period of Introduction and Role of Archigalli", I00.
} 
Nomen gentile, Brinniarius, is of unknown origin and this inscription is the only instance where it is mentioned. It is possible that this is a pseudogentilitium, which originated from a fathers name as a product of acceptance of Roman nomenclature. The suffix -ius can also be a proof of this assumption. This custom was very popular in the Celtic areas. ${ }^{39}$

Cognomen Certus is considered a common Latin cognomen. ${ }^{4}$ It is found on thirty-six inscriptions in total across the western provinces and Italy. Provinces which contain the majority of these inscriptions are Dalmatia ${ }^{41}$ and Gallia Narbonensis. Others are mostly found in northern Italy and a less significant number in other provinces. ${ }^{42}$ This cognomen was very popular in Italy and the West. ${ }^{43}$ It is an example of giving nicknames based on the quality a person can possess. This practice was very common in Roman nomenclature and in this case it is an adjective which can be translated as "reliable".

His cognomen, which is relatively often found in western provinces and is of simple Latin origin, might indicate that Sextius Brinniarius Certus originated from somewhere in the West.

The monument is dated in the $\mathrm{I}^{\text {st }}$ century BC and early $\mathrm{I}^{\text {st }}$ century AD.

Funerary monument to Publius Aelius Victor A small altar (arula) (Inscr. It. X. 3. 7; CIL V 492) made in limestone from a local quarry near Koper (height: $0,62 \mathrm{~m}$, width: $0,45 \mathrm{~m}$, thickness: 0,30 $\mathrm{m})$. Letters are not carefully engraved and the back side is rough. It stood near the church of St. Nicholas in Koper. Later it was in possession of Petronio family; Kandler and Mommsen saw and processed

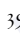

39

Fulvia Mainardis, E ora sono tutti Romani. L'evoluzione delle formule onomastiche nelle iscrizioni della Transpadanaromana (Roma, La Sapienza, 1997), 94.

40 Alföldy, Die Personennamen in der Römischen Provinz Dalmatia, 340.

Form Cirtus(!) - CIL III 13292

42 Mócsy, Nomenclator provinciarum Europae Latinarum et Galliae Cisalpinae, 75; Lőrincz, Onomasticon provinciarum Europae Latinarum, vol. II, , si; Ljubica Perinić, "O zavjetnom natpisu Minervi "Opuscula Archaeologica 23-24 (2000), 5 .

43 Alföldy, Die Personennamen in der Römischen Provinz Dalmatia, 170.

44 Kajanto, The Latin Cognomina, 34. it in their palace. It was then transferred to atrium of the gymnasium and since I9I it has been kept in the Museum of Koper. The inscription reads:

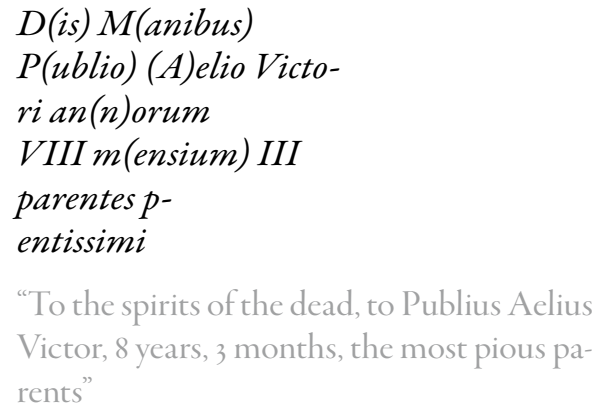

This is a funerary monument erected by the parents for their son who died young.

Tria nomina formula in which his name is written, suggests that the deceased had Roman citizenship, which he certainly obtained by birth.

His praenomen, Publius, is one of the $\mathrm{I} 8$ most common Roman names.

Nomen gentile, Aelius, is undoubtedly of Latin origin. ${ }^{45}$ It is very useful for dating, since it can be associated with emperor Hadrian, who was a member of gens Aelia. During the second century $\mathrm{AD}$ it became widespread across the Empire as Hadrian gave citizenship and established colonies in different provinces. This practice continued with Antoninus Pius who was adopted as a successor and retained the family name. ${ }^{46}$

Cognomen Victor is a very popular Roman surname of Latin origin. ${ }^{47}$ It was also very popular surname in all provinces, especially those in the West and on the frontier. Gallia Belgica, Pannonia and Italy are the regions where over one hundred fifty inscriptions with this surname come from. ${ }^{48}$ It is likely that the name was given as a "wish name" ${ }^{\prime 99}$ by parents in hope for a child to develop cer-

Alföldy, Die Personennamen in der Römischen Provinz Dalmatia, 335 .

46 Smith, A Dictionary Of Greek And Roman Antiquities, 27-28; Keppie, Understanding Roman Inscriptions, 28.

47 Alföldy, Die Personennamen in der Römischen Provinz Dalmatia, 326 and 34 I.

48 Mócsy, Nomenclator provinciarum Europae Latinarum et Galliae Cisalpinae, 311; Lörincz, Onomasticon provinciarum Europae Latinarum, vol. IV, 167-168

49 
tain qualities during life, which was a very common Roman practice. ${ }^{5}$

The name of Publius Aelius Victor suggests that he was a Roman citizen. He obtained Roman citizenship by birth. Nomen gentile Aelius was granted to his parents during or sometime after the rule of emperor Hadrian. Together with it and the use of the abbreviation DM, the inscription can be dated to the 2 nd century AD or later.

\section{Funerary monument to Publius Aelius Victor}

The exact origin of this monument is unknown, but it is thought to come from Koper (Inscr. It. X. 3. 8; $C I L \mathrm{~V}$ 493). The inscription reads:

\section{$D$ (is) M(anibus) \\ $P($ ublio) (A)elio Victori \\ annor(um) VIm(ensium) VIIId(ierum)IIII \\ P(ublius) (A)elius Quart(us) et \\ Sal L(uci)f(ilia) Nicostrat(a) \\ parentes pientissi(mi) \\ "To the spirits of the dead, to Publius Aelius \\ Victor, 6 years, 8 months, 4 days, Publius Ae- \\ lius Quartus, and Sal Nicostrata, daughter \\ of Lucius, the most pious parents"}

This funerary monument mentions three people in total: the deceased boy Publius Aelius Victor and his parents, Publius Aelius Quartus and Sal Nicostrata.

Publius Aelius Victor, the person for whom the monument is erected, was a Roman citizen, likely by birth, because the tria nomina formula is used. He could have been a relative of the Publius Aelius Victor mentioned in the previous inscription.

Hispraenomen, Publius, is one of thei 8 most common Roman names.

Nomen gentile Aelius, like in previous example, is related to Roman family name of which emperor Hadrian was the most famous member, gens Aelia. It indicates that his parents or further ancestors received citizenship during or after the rule of Hadrian.

50 Kajanto, The Latin Cognomina, 57 and 72
Victor is a very frequent cognomen found often across the Empire. ${ }^{51}$

The inscription also mentions the father of the deceased boy, whose name is Publius Aelius Quartus.

Considering his nomen gentile, Publius Aelius Quartus lived or received his citizenship during or after the rule of emperor Hadrian. It is also possible that his ancestors received the citizenship and he obtained it by birth.

Cognomen Quartus is often found among Romans and it certainly comes from Latin. ${ }^{52}$ Its origin is probably from a common Roman practice of giving nicknames to children in big families, e.g. Primus, Secundus, Tertius or Tertia etc. for females. ${ }^{53}$ However, this cognomen is found in significant numbers across the western Roman provinces, especially in the places where the Celtic population lived. The regions with highest number of inscriptions which mention this name are Noricum, northern Italy and Gallia Narbonensis. ${ }^{54}$ This might indicate a former peregrine status and maybe a Celtic origin of $\mathrm{Pu}-$ blius Aelius Quartus, but this is hard to prove.

The only things certain are that before the rule of Hadrian, he or his ancestors were not citizens, therefore they must've been peregrines or slaves. The most likely posibility is that Publius Aelius Quartus was a descendant of or a person himself who received the citizenship. Due to popularity of his cognomen in the Celtic areas, it is possible that he was named Quartus and kept this name after the conferral of citizenship or as a descendant he received the name which was already familiar among both Romans and Celts. The most likely posibility is then that he or the ancestors of Publius Aelius Quartus received citizenship as peregrines and then immigrated to Aegida during the 2nd century AD.

\footnotetext{
5I Alföldy, Die Personennamen in der Römischen Provinz Dalmatia, 326 and $34 \mathrm{I}$.

52 Alföldy, Die Personennamen in der Römischen Provinz Dalmatia, 341.

53 Matijašić, Uvod u latinsku epigrafiju, 61-62.

54 Alföldy, Die Personennamen in der Römischen Provinz Dalmatia, 278; Mócsy, Nomenclator provinciarum Europae Latinarum et Galliae Cisalpinae, 238; Lörincz, Onomasticon provinciarum Europae Latinarum, vol. IV, 167-168.
} 
Last person mentioned in this inscription is the mother of the deceased and the wife of $\mathrm{Pu}$ blius Aelius Quartus. She is Sal Nicostrata, daughter of Lucius. Although her nomen gentile (perhaps it was Salvia, as suggested in the database entry) $)^{55}$ can only be guessed, her cognomen is clearly of oriental, Greek origin. ${ }^{56}$

Since nomen gentile, cognomen and filiation are part of her name, she was certainly a Roman citizen. However, her cognomen reveals that she was probably a freed slave or a daughter of a freed slave as marriage could not have been legal if she was not a citizen.

Like in the previous inscription, nomen gentile Aelius, which was granted to the parents of the deceased or their ancestors during or sometime after the rule of emperor Hadrian, helps to date this monument. Combined with the use of the abbreviation $\mathrm{DM}$, the datation can be from 2 nd century $\mathrm{AD}$ onwards.

\section{Funerary monument of Titus Pistor, Flaminia and Maesia}

This monument is a cippus (Inscr. It. X. 3. I3), made in Aurisina limestone (height: $0,50 \mathrm{~m}$, width $0,24 \mathrm{~m}$, thickness: $0,20 \mathrm{~m}$ ). The upper, lower and right side is diminished. Lines of the letters are small and worn out. The place of finding is not known. The monument stood in the atrium of praetorial palace, then in the atrium of curia and gymnasium. Finally, in I9II, it was stored in the Museum of Koper. The inscription reads:

$$
\begin{aligned}
& \text { T. (vel P.) Ag[---] } \\
& \text { Pisto[r] v(ivus) f(ecit) [s(ibi) } \\
& \text { et] Flamini[iae --- uxori?) } \\
& \text { e]t Maes[iae --- et---] } \\
& \text { ni[---] } \\
& \text { hoc mon(umentum) [heredem non seque- } \\
& \text { tur] }
\end{aligned}
$$

\footnotetext{
55 EDRoo7638; EDCS-04200580 reconstructs the second parents name as Sal(vius) Nicostrat(us) which would make both parents males and this is almost certainly a wrong assumption.

56 Alföldy, Die Personennamen in der Römischen Provinz Dalmatia, 361.
}

\section{Titus Pistor, made it for himself while still alive, and to (wife) Flaminia, and to Maesia, this monument does not follow the heir"}

This severely damaged funerary monument mentions three persons in total. The relationship between them cannot be known with certainty.

The male person is mentioned first, Titus Pistor. While his nomen gentile is not fully preserved, its presence indicates that he was a Roman citizen.

Praenomen Titus is a very frequent Roman name.

In contrast, cognomen Pistor is mentioned only on this monument in the western provinces and Italy. It comes from Latin and likely derives from a word for an artisan. ${ }^{57}$ Giving nicknames based on occupation or profession was very common in Roman nomenclature and can be a sign of a former slave status ..$^{8}$

The second person mentioned in the inscription a female whose name is Flaminia. It is probably a nomen gentile originating from gens Flaminia, a Roman plebeian family. ${ }^{59}$

Cognomen, which would tell more about Italic or perhaps slave origin of Flaminia is not preserved, so nothing more can be told except that in the reconstruction of the inscription it is presumed that she is the wife of Titus Pistor.

Last person mentioned in the inscription is a female named Maesia. This name was very common in Italy. Its origin is Latin and it was very popular. $^{60}$

Due to the lack of use of DM abbreviation the monument can be dated in first half of the $\mathrm{I}^{\text {st }}$ century AD.

\footnotetext{
From Latin pistor, -oris, m. miller, bread-maker, baker

Kajanto, The Latin Cognomina, 322.

Smith, A Dictionary Of Greek And Roman Antiquities, I6I.

This is true for the form Maesius, since feminine form is rare, with only 7 inscriptions mentioning it; Alföldy, Die Personennamen in der Römischen Provinz Dalmatia, 337; Mócsy, Nomenclator provinciarum Europae Latinarum et Galliae Cisalpinae, 173; Barnabas Lörincz, Onomasticon provinciarum Europae Latinarum, vol. III: LABAREVS-PYTHEA (Wien: Forschunsgesellschaft Wiener Stadtarchäologie, 2000), 45
} 


\section{Funerary monument of Baburia Plotia}

This monument (Inscr. It. X. 3. I 4) was a stone box which was inscribed on the lateral side. An image was decorated on both sides where single handles stood. It supposedly stood on the gates which were called Piazzale di Porta Ognissanti (The Square of All Saints). The inscription reads:

\section{$D$ (is) $M$ (anibus)}

Baburiae Plotiae

Taronii Plotianus et Iuliane

matripientissimae

\section{"To the spirits of the dead, to Baburia Plotia, \\ Taronians Plotianus and Iuliane to the most pious mother"}

This funerary monument mentions three people from the same family.

The deceased, Baburia Plotia has a usual naming formula for women, which consists of a nomen gentile and a cognomen. This indicates that Baburia Plotia was a Roman citizen.

Her nomen gentile, Baburia is known only from Italy, so it can be considered to be of Latin origin. ${ }^{61}$ Same can be concluded for cognomen Plotia, which derives from the masculine form Plotius, which is also considered to be of Latin origin and very popular among Romans. ${ }^{62}$

Second person mentioned in the inscription is the apparent son of Baburia Plotia, Plotianus.

His name also seems to be of Latin origin, the more common form being Plotius, which was very popular in Italy, Hispania and Dalmatia, ${ }^{63}$ while Plotianus is mentioned only three times in the western provinces and Italy.

Third person mentioned is Iuliane, who is supposed to be the daughter of the deceased. Her name is also Roman and can be considered to be of

61 Mócsy, Nomenclator provinciarum Europae Latinarum et Galliae Cisalpinae, 42; Barnabas Lörincz, Ferenc Redö, Onomasticon provinciarum Europae latinarum, vol. I: Aba-Bysanus (Budapest: Archaeolingua Alapítvány, 1994), 268.

62 Alföldy, Die Personennamen in der Römischen Provinz Dalmatia, 337.

63 Lỏrincz, Onomasticon provinciarum Europae Latinarum, vol. III, 226.

64 Lỏrincz, Onomasticon provinciarum Europae Latinarum, vol. IV, 147.
Latin origin, deriving from gens Iulia. It is possible that the name Iuliane was misspelled by the engraver, since it doesn't fit in any Latin case.

The most interesting part of the inscription is the nomen gentile Taronius in the plural nominative case, which relates to Plotianus and Iuliane. The name itself seems to be quite rare ${ }^{65}$ and is limited to Italy. It is interesting to point out that five inscriptions, i.e. majority of them come from Amiternum or its vicinity, ${ }^{66}$ so there is a possibility that the name might be of ancient Sabine origin.

From te analysis of the names mentioned in the inscriptions, it is likely that it reffers to the family of Roman citizens, who all bear Roman names, Its is possible therefore that they were of Italic origin and immigrated to Aegida, maybe from central Italy.

The monument is dated to period from the beginning of the $2^{\text {nd }}$ century onwards.

\section{Funerary monument to Gaius Calpurnius Alexsa}

This monument (Inscr. It. X. 3. I $4 ;$ CIL V 495) is a plate without a frame, made in Grisignian (today Grožnjan in Croatia) limestone, broken in two pieces (height: $0,44 \mathrm{~m}$, width: $0,57 \mathrm{~m}$ ). Letters are finely inscribed and deep-cut. Kandler and Mommsen wrote the inscription down while it stood on the public square (Loggia), from where it was placed in the atrium of the gymnaisum. Since I9II, it has been inserted into the wall of the Koper museum. The inscription reads:

C(aius) Calpurnius

C(ai) Frugi l(ibertus)

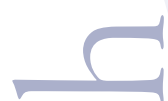

Alexsa

Sabinnaeus

filius patri

de suo

peculio fecit

Lőrincz, Onomasticon provinciarum Europae Latinarum, vol. IV, 226.

66 CIL I 3292, CIL IX 4302, AE 1992, 0484, AE 1992, 0486, AE i992, 0487 . 
Gaius Calpurnius Alexsa, freedman of Ga-

ius Frugi, son Sabinnaeus erected (this monument) to his father at his own expense"

This is a funerary monument which mentions a liberated slave Gaius Calpurnius Alexsa, his former master Gaius Calpurnius Frugi and his son Sabinnaeus.

After manumission of Gaius Calpurnius Alexsa, praenomen and nomen gentile of his former master became a part of his new Roman name, as it was common Roman practice. ${ }^{67}$

Nomen gentile Calpurnius was a very common Roman name, especially among the senatorial class. This nomen gentile was very popular in Liburnia and western Istria, ${ }^{68}$ but also in Italy and Hispania, where over one hundred and thirty inscriptions with this name were found. Its origin is from gens Calpurnia, which rose to prominence after the Punic Wars. Many members of this gens became consuls. ${ }^{69}$

His single slave name, Alexsa, became cognomen, which was a common practice for that social class. ${ }^{7}$ Alexsa is likely of oriental, Greek origin and is attested in only one other inscription in the western provinces. ${ }^{71}$ Entry in the database offers a possibility that form Alexsa is shortened from Alexsander. ${ }^{72}$ However, since there was enough room on the plate to inscribe the suggested full name but it was not done, probably the name Alexsa is the correct reconstruction.

Inscription in this monument also mentions the former master of the deceased. His name is Gaius Calpurnius Frugi.

His praenomen, Gaius is one of the 18 most common Roman names.

67 Salway, "What's in a Name?", I27; Matijašić, Uvod u latinsku epigrafiju, 62 .

68 Alföldy, Die Personennamen in der Römischen Provinz Dalmatia, 70.

69 Smith, A Dictionary Of Greek And Roman Antiquities, 582.

70 Matijašić, Uvod u latinsku epigrafiju, 67.

71 Lőrincz, Redő, Onomasticon provinciarum Europae Latinarum, vol. $\mathrm{I}, 74$.

72 EDCS-04200582 Epigraphik - Datenbank Clauss - Slaby. http:// www.manfredclauss.de (16.7.2015).
Nomen gentile Calpurnius, as above, was a name of very prominent family that several consuls.

Cognomen Frugi is quite rare, with only one other inscription mentioning this surname in Italy. ${ }^{73}$ The origin of the name comes from the practice of giving nicknames which denote certain quality, in this case honesty of virtuousness. ${ }^{74}$ The lack of mention of this surname in the inscriptions is contrasted by several important individuals recorded in the history that bore this surname. The most famous one is likely M. Licinius Crassus Frugi, consul in 27 AD. This particular individual, the former owner of the deceased, was related to C. Calpurnius Crassus Frugi Licianus, who lived during the rule of Nerva.

The last person mentioned in the inscription is the son of the deceased, Sabinnaeus. This monument is the only instance where this name is written in this form. ${ }^{76}$ Form Sabinus is much more common in all parts of the Empire, especially southern Italy and its origin is Latin. ${ }^{77}$ It is related to the ethnic name of the Sabines, but in this case it is probably not a sign of person's ethnicity, rather a manifestation of a practice of giving nicknames originating from the names of nations. $^{78}$

His father being a liberated slave, tria nomi$n a$ is expected to be used for Sabinnaeus. Reason for the lack of it is maybe the fact that there was no room on this plate or funds to buy a larger stone plate to inscribe everything intended.

The monument can be dated to the $\mathrm{I}^{\text {st }}$ century $\mathrm{AD}$.

3 Lỏrincz, Onomasticon provinciarum Europae Latinarum, vol III, 154; a prominent individual with this surname was M. Licinius Crassus Frugi, consul in $27 \mathrm{AD}$.

74 From the Latin frūgi adj. indecl. proper, worthy, honest, virtuous, frugal; Kajanto, The Latin Cognomina, 253 .

75 Degrassi, Inscriptiones Italiae, Vol. X., Regio X, Fasc. III, Io.

76 Mócsy, Nomenclator provinciarum Europae Latinarum et Galliae Cisalpinae, 248; Lörincz, Onomasticon provinciarum Europae Latinarum, vol. IV, 167-168.

77 Alföldy, Die Personennamen in der Römischen Provinz Dalmatia, 117 and 34I; Lörincz, Onomasticon provinciarum Europae Latinarum, vol. IV, 40 .

78 Kajanto, The Latin Cognomina, I85 


\section{Funerary monument of Quintus Cervius} Fidelis

This monument (Inscr. It. X. 3. 16; CIL V 496) is a stone plate without a frame, made in Aurisina limestone (height: $0,44 \mathrm{~m}$, width: $0,45 \mathrm{~m}$, thickness: $0,20 \mathrm{~m}$ ). It stood the house of Aurelli de Belli, near his garden. Kandler and Mommsen saw it in the public squre (Loggia), from where it came to the atrium of the gymnasium. From I9II it has been kept in the Museum of Koper. The inscription reads:

\section{Q(uintus) Cervius Q(uinti) l(ibertus) Fidelis v(ivus) f(ecit) sib(i) \\ "Quintus Cervius Fidelis, freedman of Qu- intus, made it for himself while still alive}

This monument mentions two persons: a liberated slave and his former owner.

Quintus Cervius Fidelis is mentioned to be a freedman, which means that he obtained Roman citizenship by manumission.

Praenomen and nomen gentile of his master, who is mentioned only as Quintus, became a part of his new Roman. His masters name might have been Quintus Cervius, while his cognomen is unknown.

His praenomen, Caius is one of 18 most common Roman names.

Nomen gentile Cervius likely comes from Latin..$^{79}$ It is found on fifteen inscriptions across the West, of which eight are from Italy. ${ }^{80}$

It the provinces, it signifies the population of Italic origin, as it is suggested by Alföldy in the case of Dalmatia. ${ }^{8 \mathrm{r}}$ On the other hand, at least the root of this name is related to indigenous population, especially in Istria. ${ }^{{ }_{2}}$

\footnotetext{
79 Alföldy, Die Personennamen in der Römischen Provinz Dalmatia, 336.

80 Mócsy, Nomenclator provinciarum Europae Latinarum et Galliae Cisalpinae, 76; Lőrincz, Onomasticon provinciarum Europae Latinarum, vol. II, 5 I.

8I Alföldy, Die Personennamen in der Römischen Provinz Dalmatia, 75.

82 Hans Krahe, Lexikon Altillyrischer Personennemen (Heidelberg: Carl Winter's Universitätsbuchhandlung, 1929), 28; Starac, "Pitanje istočne granice Cisalpinske Galije i odnos općina Tergeste i Egida”, 29.
}

Cognomen Fidelis is likely of Italic and certainly of Latin origin. ${ }^{83}$ This cognomen derives from the practice of naming people with nicknames which present moral and social qualities ${ }^{84}$ and was very popular among freedman. ${ }^{85}$ It is found in a relatively significant number of inscriptions, most of which are from Italy. ${ }^{86}$

From the observations and data mentioned above, it can be summarized that Quintus Cervius Fidelis was a manumitted slave. Since he was named after his owner and the cognomen is of Latin origin, nothing more can be known about Quintus Cervius Fidelis.

On the other hand, the owner and later patron of Quintus Cervius Fidelis, who bears a true Roman name and the root of the nomen gentile which is considered by authors to be of indigenous origin, is probably a descendant of indigenous Istrian population which was apparently already Romanized to some extent in the ist centruy AD.

The date when this monument was made can be asserted on the basis of one epigraphic feature. It is lack the of DM abbreviation, which was in common use by the middle of the ind century AD in this geographical area. The date can then be set to the first half of the ist century AD.

\section{Funerary monument of Caelotis Naevola}

This monument exists only as a drawing (Inscr. It. X. 3. I8; CIL V 498). It was supposedly found in Koper, but an anonymous traveller reports having seen it in the vicinity of the village St. John of Dajla, in the wall of count Grisonis's house. Count Grisoni, a nobleman from Koper, saw it fit to take it from that village and transfer it elsewhere. It was not found afterwards. The inscription reads:

\footnotetext{
83 Alföldy, Die Personennamen in der Römischen Provinz Dalmatia, 340.

84 From Latin fidelis, e, adj. trusty, trustworthy, faithful, sincere, true.

85 Kajanto, The Latin Cognomina, 203 and 254.

86 Mócsy, Nomenclator provinciarum Europae Latinarum et Galliae Cisalpinae, 126; Lörincz, Onomasticon provinciarum Europae Latinarum, vol. II, I40-141.
} 
$D(i s) M$ (anibus)

Celotis

Naevola

Mater

To the spirits of the dead, Celotis Naevola,

mother

This funerary monument mentions only one female person, the deceased Celotis Naevola. Her name is written in common onomastic formula for women, which indicates that she was a Roman citizen. Both her nomen gentile and cognomen are very rare.

Nomen gentile Celotis is attested only in this inscription.

The form Gelotis is attested in the surviving drawing of the inscription, which is also quite rare but a broad outline of the name can be discerned. It is found only in Italy and three inscriptions mention it, all in genitive case and concerning mostly former slaves. ${ }^{88}$ However, the name is also mentioned on numerous brick stamps found in Rome. They are related to Tiberius Servilius Gelos who worked for figlina Caepioniana in the beginning of the 2nd century $\mathrm{AD}^{89}$

Although it is hard to find a connection between all these inscriptions and their forms with the one from Koper, in the widest sense it can be concluded that this name and forms of this name are found among former slaves.

Cognomen Naevola is also found in only one other inscription. ${ }^{9 \circ}$ It is likely that her cognomen comes from the Latin word for mole or wart ${ }^{9 \mathrm{~T}}$ as giving nicknames for physical attributes was very common in Roman times. ${ }^{22}$

With both nomen gentile and cognomen being very rare, it is possible that this individual was

87 Mócsy, Nomenclator provinciarum Europae Latinarum et Galliae Cisalpinae, 58; Lörincz, Onomasticon provinciarum Europae Latinarum, vol. II, 18 .

88 CIL V 6808, AE 2001,576 and CIL XI 6712.

89 John P. Bodel, Roman Brick Stamps in the Kelsey Museum (Ann Arbor: University of Michigan Press, 1983), 25 .

In the masculine form Naevolus - CIL V 6447.

Lat. naevus, -i, m. mole, wart.

Kajanto, The Latin Cognomina, 245; Matijašić, Uvod u latinsku epigrafiju, 6r. of peregrine or slave status who later acquired citizenship.

The datation of this monument can be asserted on the basis of the use of DM abbreviation, which can date it in the ist AD.

\section{Funerary monument to Lucius Herennius and Lucius Priscus}

This monument is also only preserved in form of a drawing which depicts a stella with many cracks and its right side cut-off (Inscr. It. X. 3. 19; CIL $\mathrm{V}$ 499). It was supposedly found in the wall of the Episcopal garden. It is now considered lost. The inscription reads:

$$
\begin{aligned}
& \text { L(ucius) Here[nnius--] } \\
& \text { Pup(inia) i[---] } \\
& \text { v(ivus) f(ecit) s(ibi) } \\
& \text { et L(ucio) Pu[---] } \\
& \text { Prisc[co---] } \\
& \text { "Lucius Herennius, of the Pupinia tribe, } \\
& \text { made it for himself while still alive and for } \\
& \text { Lucius Pu[---] Priscus" }
\end{aligned}
$$

This monument mentions two male persons but the damage and subsequent loss of the stone plate makes the reconstruction of the names difficult.

First person mentioned is Lucius Herennius.

His praenomen, Lucius, is one of 18 most common Roman names.

Nomen gentile Herennius is very frequent in the western provinces and Italy. ${ }^{93}$ The family name comes from gens Herennia. It was a plebeian family of Samnite origin, whose members became very influential and held important political and military offices. They even entered imperial families as the wife of emperor Decius was Herennia Etruscilla. ${ }^{94}$ The name is considered to be of Latin origin..$^{5}$

\footnotetext{
93 Mócsy, Nomenclator provinciarum Europae Latinarum et Galliae Cisalpinae, 143; Lörincz, Onomasticon provinciarum Europae Latinarum, vol. II, $178-179$

94 Smith, ADictionary Of Greek And Roman Antiquities, 406-407.

95 Alföldy, Die Personennamen in der Römischen Provinz Dalmatia, 335 .
} 
The damage of the monument makes the rest of his name difficult to reconstruct. The part where the abbreviation Pup(inia) ends, a hasta which resembles letter " $I$ " is recorded on the drawing. It was ommited in the first publication of the monument and also on the proposed transliteration. Even if this hasta is not ignored as a mistake made during the drawing of the monument, the Pup(inia) part left in the inscription can be reconstructed as an affiliation to tribus Pupinia, which was one of thirty-five Roman tribes. $^{96}$

In any case, it doesn't change the fact that Lucius Herennius was likely a Roman citizen, perhaps of Italic origin.

Second person mentioned on this inscription is Lucius Priscus, also the deceased for whom the same monument was erected.

His praenomen Lucius, like in the previous case, is one of the most common ones used by Romans.

Due to damage of the monument, his nomen gentile is not entirely preserved, only the $P u$ part is visible.

His cognomen, Priscus, is certainly of Italic and Latin origin. ${ }^{97}$ In the most ancient times the name was considered Etruscan, but in the later periods became a common Roman surname. The popularity of the name is due to connection to the legendary figure of the Roman king, Tarquinius Priscus. ${ }^{98}$ It is found in large numbers across various western provinces. Most of the inscriptions with this surname come from Italy, where one hundred fifty of them are recorded. ${ }^{99}$

The datation of this monument can be set on the basis of two epigraphic features. Lack of DM abbreviation, which was in common use by the 2 nd century AD and the use VF abbreviation, which was used from middle and the end of Ist

96 Keppie, Understanding Roman Inscriptions, I40; Matijašić, Uvod u latinsku epigrafiju, 66.

97 Alföldy, Die Personennamen in der Römischen Provinz Dalmatia, 273 and 341 .

98 Kajanto, The Latin Cognomina, 7 I

99 Mócsy, Nomenclator provinciarum Europae Latinarum et Galliae Cisalpinae, 232; Lőrincz, Onomasticon provinciarum Europae Latinarum, vol. III, I62-163. century AD until the second half of 2 nd century AD the datation of the monument can be then set from the first half up to the middle of the ist century AD.

\section{Funerary monument of Gaius Lorentius Tesifon}

This monument is stone box made in Aurisina limestone (Inscr. It. X. 3. 20; CIL V 500). It is divided into three parts with numerous cracks and damages. The letters are rough and the inscription is written continuously (height: 0,65 m, width: 2,03 $\mathrm{m}$, thickness: $0, \mathrm{I} 4 \mathrm{~m}$ ). The monument stood near the Square of All Saints (Piazzale di Porta Ognissanti), from which it was later pulled down and lay near the well. Kandler and Mommsen saw it in the public square (Loggia), from where it came to atrium of the gymnasium. From I9I it has been kept in the Museum of Koper. The inscription reads:

$G$ Lorentius

Tesifon vibus

posuit sibi

"Gaius Lorentius Tesifon, placed it for him self while still alive"

The monument is of funerary character and mentions only one person, Gaius Lorentius Tesifon.

Tria nomina fromula suggests that he was a Roman citizen.

His praenomen, Lucius, is one of 18 most common Roman names.

Lorentius is a rare nomen gentile and there is only one other instance where it is recorded in this form. ${ }^{100}$ Much more frequent is Laurentius, which is certainly of Latin and Italic origin.

Cognomen Tesifon is also unique in the western provinces. It is undoubtedly of oriental origin. It is possible that this name can be related to the capital of Parthian and Sasanian Empire, Ctesiphon, which would indicate the origin more precisely. Cognomen which has a root in a geograp-

I00 Feminine form Lorentia in CIL V 1276. 
hical term was often used in Roman nomenclature, especially among former slaves. ${ }^{101}$

From these observations it can be concluded that Gaius Lorentius Tesifon was a Roman citizen who obtained citizenship probably by way of manumission. His cognomen was likely his single slave name, which is of oriental origin.

Here it is possible to make an assumption on the manner in which this individual may have end ded up in the area around Aegida during the 3 century AD. His arrival perhaps can be related to the conquest of Parthia and the sack of its capital, Ctesiphon, by emperor Septimius Severus in 197 AD. It is reported that the large number (around ten thousand, according to Cassius Dio) of slaves were captured and distributed across the Empire after this expedition ${ }^{\text {102 }}$. Although this corellation cannot be proved with utmost certainty, it is not impossible that a slave was manumitted after years of service and as a cognomen took the name of his hometown, which was destroyed and from which he was taken as a prisoner.

The datation of this monument can be asserted only on the basis of one epigraphic feature, which is the use of the formula vibus posuit. This formula was common in the Late Principate. ${ }^{103}$ The date can be therefore set to 3 rd century AD.

\section{Funerary monument of Lucida Dignitas}

This monument is a stella made of limestone (Istrian, but it is not determined which exactly), with an inscription written in finely engraved letters and in continua (Inscr. It. X. 3. 2I). The inscription field is framed by a triple moulded belt. The pediment of the stella is decorated with a rose and leaves. The stella was found in the gardens of Capuchin mon$\mathrm{ks}$, while excavating the well. It stood in the curia, after it came to the atrium of the gymnasium. From I9II, it is inserted in the wall of the Museum of Koper. The inscription reads:

\footnotetext{
IOI Kajanto, The Latin Cognomina, 45 .

102 D.C.LXXVI.9.4.

I03 Miroslav Glavičić, "Tri rimskodobna natpisa iz Senja", Senjski zbornik $23(1996), 26$
}

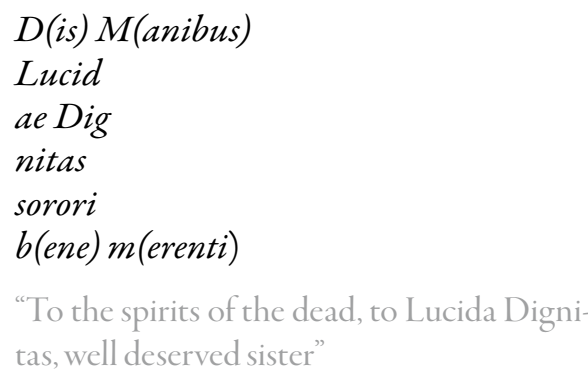

This is a funerary monument erected for $\mathrm{Lu}$ cida Dignitas. Judging by the two names which were a common onomastic practice for women, she was a Roman citizen.

Both her nomen gentile and cognomen are very rare. Lucida is only attested as a cognomen in twenty inscriptions in the western provinces and Italy. Even in other publications, Lucida from this inscription is recorded as cognomen. ${ }^{104}$

The real cognomen, Dignitas is also quite rare. There is only one other instance where the name is recorded in this form. ${ }^{105}$ Its origin is from the practice of giving names related to moral qualities of the person, in this instance the meaning being "worthy". ${ }^{106}$

While being very rare, both names are almost certainly of Latin origin. It is likely that Lucida Dignitas was a Roman citizen, maybe of Italic origin.

The use od DM abbreviation can date this monument in the ist century $\mathrm{AD}$ onwards.

\section{Funerary monument to Tullia Septimina}

A side of a stone box, made in Aurisina limestone (height: $0,55 \mathrm{~m}$, lenght: $0,55 \mathrm{~m}$, width: $0,36 \mathrm{~m}$ ). The inscription (Inscr. It. X. 3. 23; CIL V 504) is in the front and the box is decorated on both sides with two handles. It was used to store oil in the Koper drugstore. Later it changed places from curia to the atrium of the gymnasium, and in I9II it was placed in the Koper Museum. The inscription reads:

\footnotetext{
I04 Lörincz, Onomasticon provinciarum Europae Latinarum, vol. III, 35.

Ios Mócsy, Nomenclator provinciarum Europae Latinarum et Galliae Cisalpinae, 103; Lörincz, Onomasticon provinciarum Europae Latinarum, vol. II, 100

I06 From Latin dignitas, -atis, f. worth, merit, desert, character; Kajanto, The Latin Cognomina, 95 .
} 
Tulliae Septiminae

animae inocentissimae

quae vixit annis VI mens(ibus) VIIII

diebus VII Tullia Privata

mater in $(f)$ elicissima

"To Tullia Septimina, of the most innocent

soul, who lived to 6 years, 9 months, 7

days, Tullia Privata, the most unfortunate mother"

This funerary monument mentions two female persons, the deceased daughter and her mother who erected the monument.

The daughter, who died quite young, judging by the two names, was a Roman citizen by birth.

Nomen gentile Tullia belongs to one of the most ancient Roman gens, whose patrician branch was already extinct in the early Republic. The name (except for a few notable individuals, of whom Marcus Tullius Cicero is the most famous one) was common among freedmen. ${ }^{107}$

Cognomen Septimina has an origin from a common Roman practice of giving nicknames related to number of children in big families, which later became an usual cognomen.

Cognomen Privata is a frequent Roman surname of Latin origin. ${ }^{109}$ The highest number of inscriptions with this name come from Italy. ${ }^{110}$ The word itself derives from the practice of giving names originating from a certain social class.

Considering all this, both persons were Roman citizens and their Latin names might indicate that they were of Italic origin. While the mother might have been a freedman, the deceased daughter probably received citizenship by birth.

This monument can be dated on the basis of several epighrapical and onomastical features. First is the use of the form annis, which along

107 Smith, ADictionary Of Greek And Roman Antiquities, 1183.

I08 Matijašić, Uvod u latinsku epigrafiju, 6I-62.

I09 Alföldy, Die Personennamen in der Römischen Provinz Dalmatia, 34 I.

i o Mócsy, Nomenclator provinciarum Europae Latinarum et Galliae Cisalpinae, 232; Lörincz, Onomasticon provinciarum Europae Latinarum, vol. III, 165 .

I I Kajanto, The Latin Cognomina, 315 . the form annos, is common from 2 nd century AD. Secondly, the precise lifetime of the deceased being recorded on the monument, including years, months and days, became common in the 3 rd century A.D. ${ }^{\mathrm{II}}$ Datation of this monument can then be set in the 3 rd century AD.

\section{Bronze plate with inscribed names of liberated slaves}

This inscription (Inscr. It. X. 3. 30; CIL V 50I) is on a fragment of a bronze plate (height: $0,15 \mathrm{~m}$, width: $0,12 \mathrm{~m}$, thickness: $0,006-0,009 \mathrm{~m})$. It was found near Koper, in the place called Arjol, between St. Michael and the Lazaretto, on the estate of Ingaldes, a noble familiy of Koper. It is unknown how at one point the plate turned up in Vienna, but now it is kept in the Archaeological Museum of Istria, in Pula. The inscription reads:

---] Magaplina Mati (vel Matt) [---an(no rum)---, M]agaplina Tertiae lib(erta) [an(orum)--]

Magaplina Tertiae [lib]erta an(norum) [---] [Ma] gaplina Raecif(ilia) an(nnorum) LX [-Maxi]ma f(ilia) an(norum) X[--- Magaplin]us Maximaefiliae f(ilius) an (norum) [---] Magaplinus [Ma] rcellae

lib(ertus) an(norum) [---] Magaplinus [M]

arcel

lae lib(ertus) [an(norum) ---], Magaplina [Mar]cellae lib(erta) [an(norum)---

"Magaplina Mati, years

Magaplina, freedwoman of Tertia, years

Magaplina, freedwoman of Tertia, years

Magaplina, daughter of Raecus, years 60, daughter Maxima

years io, Magaplinus, son of daughter of

Maxima, years, Magaplinus, freedman of

Marcella, years, Magaplinus, freedman of

I 2 Keppie, Understanding Roman Inscriptions, 107 
Marcella, years, Magaplina, freedwoman of

Marcella, years"

This bronze plate records the names of liberated slaves, their age and names of former masters. The inscription records the family of Magaplines and their former owners. This plate is likely a legal document related to granting the Roman citizenship to people mentioned in the inscription. ${ }^{113}$

The first and most often inscribed name on this plate is Magaplinus in feminine and masculine gender. Since the plate records the names of liberated slaves, it is obvious that Magaplinus and Magaplina served as a single name before their manumission. Magaplinus is attested only in Italy as a nomen. ${ }^{114}$ The origin of the name is neither Roman nor the word comes from Latin. It's related to the name Aplis, which with its few derivatives ${ }^{115}$ was preserved in the form of Magaplinus. Different authors point out distinctly Illyrian origin due to lingustic features or Venetic due to geographical prevalence which is mainly Istria. However, all agree that it is a name of indigenous origin. ${ }^{116}$ This is further confirmed by the onomastic formula, which consists of nomen gentile (moved in the place which is usually reserved for cognomen in Roman nomenclature and filiation. This onomastical order is very characteristical for Histrian and Liburnian names.

Consideringa all this, people who bore the name Magaplinus or Magaplina mentioned on this plate, were likely the members of indigenous population living somewhere in Istria. ${ }^{118}$

Second name that can be related to indigenous population mentioned on the inscription is Raecus. Since in this inscription it appears as the

I 3 Starac, "Pitanje istočne granice Cisalpinske Galije i odnos općina Tergeste i Egida ", 3 I.

I 4 Mócsy, Nomenclator provinciarum Europae Latinarum et Galliae Cisalpinae, 173; Lörincz, Onomasticon provinciarum Europae Latinarum, vol. III, 45

I Is Other forms include: Aplo, Apludus, Aplurus, Aplus, Aplius.

I16 Krahe, Lexikon Altillyrischer Personennemen, 157; Starac, "Pitanje istočne granice Cisalpinske Galije i odnos općina Tergeste i Egida”, 30; Mate Križman, Rimska imena u Istri: osobna imena na istarskim natpisima iz rimskog doba (Zagreb: Latina Et Graeca, 1991), 200-201.

I 7 Starac, "Pitanje istočne granice Cisalpinske Galije i odnos općina Tergeste i Egida", 31 .

i 8 John J. Wilkes, The Illyrians (Cambridge: Blackwell Publishing, I992), 7 I -75 names of the parents of freedman, it is also of indigenous origin and indicates a slave past. The name is considered to be of Illyrian, but can be also considered Venetian, especially in the northern Italy. ${ }^{119}$

The names of the masters who liberated these slaves are also mentioned. They are Maxima, Marcella and Tertia. These are Roman names of Latin origin and it is not surprising that owners of these slaves are Romans, likely of Italic origin.

For the datation of this monument, only one epigraphical feature can be used. In the offered transliteration, abbreviation an is restituited as an(nnorum). If this reconstruction is accepted, then the plate can be dated to the I century AD.

\section{Funerary monument of Caius Titius}

This monument (Inscr. It. X. 3. 31; CIL V 486) is a stone plate made in limestone, with a frame made of triple moulded belt (height: $0,98 \mathrm{~m}$, width: $0,65 \mathrm{~m}$ ). It was found in 1843 , in a valley near the village of Pomjan (Italian: Paugnano), near Koper. Soon after the finding, it arrived in the Museum of Trieste, where it has been kept inserted in the wall. The inscription reads:

\section{$C$ (aius) Titius $C$ (ai)f(ilius) \\ Volt(ilia) Vienna \\ veteranus \\ leg(ionis) XV Apol(linaris) \\ "Gaius Titius, son of Gaius, Voltilia, from Vi- enne, veteran of isth legion of Apollonians"}

This is a monument of legionary veteran, who also inscribed the name of his hometown and legion in which he served.

His praenomen, Gaius is one of $\mathrm{I} 8$ most common Roman names.

His nomen gentile, Titius, is related to old but not very prominent plebeian family, gens $T i$ $t_{i a}{ }^{120}$ and is certainly of Latin origin. ${ }^{\text {. }}$

I1 Krahe, Lexikon Altillyrischer Personennemen, 97; Alföldy, Die Personennamen in der Römischen Provinz Dalmatia, 349; Križman, Rimska imena u Istri, 104.

120 Smith, A Dictionary Of Greek And Roman Antiquities, 1159 .

I21 Alföldy, Die Personennamen in der Römischen Provinz Dalmatia, 338 
This monument might seem peculiar at first because it lacks the cognomen. It was actually a common practice in the area around Aquileia and Emona for veterans to omit cognomen but to regulary include the tribe in which they were enrolled. ${ }^{\text {I22 }}$

Gaius Titius also inscribed his filiation, which reveals that his fathers name was also Gaius. His voting tribe is recorded to be Voltilia, the tribe of his hometown, Colonia Iulia Vienna Allobrogum, todays Vienne in southeastern France, south of Lyon.

From this it is easy to assert that this individual was native of Gaul, who served as a legionnaire in the isth legion of Apollonians.

This legion was raised by Octavian sometime around 40 or $4 \mathrm{I} \mathrm{BC}$. After Actium, where the legion fought, it received the title in the honor of Apollo ${ }^{123}$ and was stationed in Illyricum, the precise location being a point of debate. It is possible that it had a camp in Carnuntum near todays Vienna in Austria. The date for its occupation of Carnuntum range from Is $\mathrm{AD}$ to $50 \mathrm{AD} .^{124}$ It was previously thought that this legion had a camp in Ljubljana (Emona) ${ }^{125}$ before transfering to Carnuntum, but this hypotesis is now mostly rejected. ${ }^{126}$ In $55 \mathrm{AD}$, during the rule of Nero, the legion was transferred to the East to fight Parthians and participated in the First Jewish Revolt, but returned to Pannonia (Carnuntum) in

\footnotetext{
122 Marjeta Šašel-Kos "The isth Legion at Emona-some Thoughts", Zeitschrifffür Papyrologie und Epigraphik I09 (1995), 238.

123 E. Ritterling, "Legio" in RE XII (Stuttgart: J. B. Metzler, 1924-1925), 1747; Keppie, Understanding Roman Inscriptions, I82.

I24 Everett L. Wheeler, "Legio XV Apollinaris: From Carnuntum to Satala and beyond "in Les Légions de Rome sous le Haut-Empire, ed. Y. Le Bohec (Lyon/Paris: De Boccard, 2000), 272-273; Jerome H. Farnum, The Positioning of the Roman Imperial Legions (Oxford: Archaeopress, 2005), 23.

I25 This view became widely accepted in literature despite serious doubts being cast on it very early. Works which supported this idea include: B. Saria, "Emona als Standlager der Legio XV. Apollinaris" in Laureae Aquincenses i Diss. Pann. 2. I. (1938) 245-255; G. Alföldy, Noricum, 1974, 57; A. Mocsy, Pannonia and Upper Moesia, 74-76; J. Fitz, The Archaeology of Roman Pannonia, 1980, 143.

I26 Šašel and Weiler, "Zur augusteisch-tiberischen Inschrift von Emona", Carnuntum Jahrbuch 8 (1963-1964), 40-42; Šašl-Kos "The 15th Legion at Emona", 243.
}

71 AD. ${ }^{127}$ Save a small contribution in the conquest of Dacia (only as a vexilation), the legion stayed in Carnuntum until it was dispatched to the East sometime during the rule of Trajan never to return to Pannonia.

The fact that Gaius Titius served in a legion, and not in an auxiliary unit, indicates that he was a Roman citizen and not a peregrine who joined the army from Gaul and received citizenship upon retirement. As a veteran, Gaius Titius settled somewhere in northern Italy and Istria, similiar to other veterans of this legion, who often retired in the hintherland of Aquileia. ${ }^{\text {I2 }}$

The datation of this monument can be conjectured on the basis of the movement of the legion. During the ist century BC and AD, the legion spent the majority of its time in Illyricum and later Pannonia Superior $(55-71$ AD was spent in the East), mostly in Carnuntum. Therefore, the monument can be dated to early ist century AD.

\section{Funerary monument of Publius Acisinus}

\section{Venius and his wife Galla}

This monument (Inscr. It. X. 3.32; CIL V 49I) is a stone plate with a frame made of triple moulded belt. It was found in an unknown place near the village of Pomjan (Italian: Paugnano). With it, jars, perfume bottle and a lamp with the FORTIS stamp were found. Unfortunately, Kandler himself lost the plate in 1844 . The inscription reads:

\section{$P$ (ublius) Acisinius C(ai)f(ilius) \\ Venius \\ Galla uxor}

"Publius Acisinius Venius, son of Gaius, wife Galla"

I27 Andras Mócsy, Pannonia and Upper Moesia: A History of the Middle Danube Provinces of the Roman Empire (London/Boston: Routledge and K. Paul, 1974), 48; Wheeler, "Legio XV Apollinaris: From Carnuntum to Satala and beyond ", 260.

128 Mócsy, Pannonia and Upper Moesia, 99; Wheeler, "Legio XV Apollinaris", 260; Farnum, The Positioning of the Roman Imperial Legions, 23.

I29 Jaroslav Šašel "Zur Frühgeschichte der XV. Legion und zur Nordostgrenze der Cisalpina zur Zeit Caesars" Archäeologisch-epigraphische Studien I (1985), 547. 
This is a funerary monument which mentions two persons, husband and wife.

Tria nomina formula suggests that Publius Acisinius Venius was a Roman citizen. His filiation reveals tha he was son of Gaius.

Praenomen Publius is one of the most used Roman names.

Nomen gentile Acisinus is quite rare, this inscription being the only one containing it in Italy and the western provinces. ${ }^{130}$ Authors have suggested that it might be of Etruscan or more likely, of Illyrian origin. ${ }^{\text {. }}$

Cognomen Venius is practically unknown and is recored only as a nomen on two inscriptions. ${ }^{\text {I3 }}$

It is very hard to discern the origin of this person or its name, especially because he has a very unusual combination of non-Latin nomen gentile and cognomen, together with the filiation in genitive case, but with a common Roman name. If his nomen gentile is not of Italic origin, then it is possible that Publius was a former peregrine who obtained the citizenship later in life, despite his father having a proper Roman praenomen.

The inscription also mentions the name of the wife. There are conflicting vievs if the name inscribed is Galla or Calla. It is probably a cognomen and because of that, it is possible that the wife was a freedwoman or a peregrine whose name was not fully recorded.

This monument has only one epigraphical feature which can date it and that is the lack of DM abbreviation, which can then set the date to ist century AD.

\section{Funerary monument of Publius Sardius Prudens}

This is a stella (Inscr. It. X. 3. 33; CIL V 503) made of local limestone (height: $\mathrm{I}, 37 \mathrm{~m}$, width: 0,44

130

Mócsy, Nomenclator provinciarum Europae Latinarum et Galliae Cisalpinae, 3; Lörincz, Redö, Onomasticon provinciarum Europae Latinarum, vol. I: Aba-Bysanus, I5.

I3 I Krahe, Lexikon Altillyrischer Personennemen, i6; Križman, Rimska imena u Istri, 103.

I32 Mócsy, Nomenclator provinciarum Europae Latinarum et Galliae Cisalpinae, 305; Lőrincz, Redő, Onomasticon provinciarum Europae Latinarum, vol. I: Aba-Bysanus, 154. $\mathrm{m}$, thickness: $0,13 \mathrm{~m}$ ). The pediment is decorated with a rose inside, with single dolphins represented on the sides. It was found in the village of Monte, in the the wall of the church of St. Mary. It still stands there. The inscription reads:

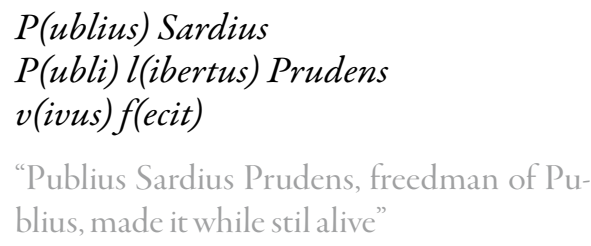

The monument records the name of citizen Publius Sardius Prudens, who obtained the citizenship by manumission and his former master, Publius.

Pranenomen Publius is one of the most often used Roman names.

Nomen gentile Sardius is quite rare, with only two inscriptions from Italy, including this one, mentioning it. ${ }^{\mathrm{I} 33}$ It is likely that upon his manumission, the former slave inherited it from his new patron. His master was probably a member of indigenous population living in Istria and northern Italy, as the root of the name is considered to be of such origin. ${ }^{\mathrm{I} 4}$

Cognomen Prudens in this form is attested on eighteen inscriptions in the western provinces and Italy $^{\mathrm{I} 35}$. However, different forms of this name, e. $\mathrm{g}$. Prudentia and Prudentius, are relativley common. Its origin is Latin and can be considered a true Roman cognomen which was given to denote a special quality a person possessed, in this case a mental qualitiy ${ }^{136}$, a common practice in Roman nomenclature. ${ }^{\mathrm{I} 37}$ It is likely that this indvidiual served his

\footnotetext{
I33 Mócsy, Nomenclator provinciarum Europae Latinarum et Galliae Cisalpinae, 253; Lörincz, Onomasticon provinciarum Europae Latinarum, vol. IV, 49 .

I34 Wilhelm Schulze, Zur Geschichte lateinischer Eigennamen (Berlin-Zürich-Dublin: Weidmann, 1966), I 13; Starac, "Pitanje istočne granice Cisalpinske Galije i odnos općina Tergeste i Egida”, 29.

I35 Mócsy, Nomenclator provinciarum Europae Latinarum et Galliae Cisalpinae, 235; Lörincz, Onomasticon provinciarum Europae Latinarum, vol. III, 169 .

I36 From the Latin prudens, -entis, adj. knowing, skilled, experienced, versed.

I37 Alföldy, Die Personennamen in der Römischen Provinz Dalmatia, 250; Kajanto, The Latin Cognomina, 34 I
} 
master well and this was in a way reflected in the cognomen which was given to him.

The monument is dated in the early $\mathrm{I}^{\text {st }}$ century AD.

\section{Monument of Sextius Pedanius Seneca}

This monument (Inscr. It. X. 3. 34) is a plinth made in sandstone (height: $0,13 \mathrm{~m}$, width: $0,25 \mathrm{~m}$, thickness: $0,12 \mathrm{~m}$ ). The right side is damaged, and the inscription is engraved with rough letters. Stones of the same shape were found in few tombs in Istria. The monument was found in wall in the field near the village of Zupanci. It was kept in the curia of Paugnano, until it came to the Museum of Koper as a gift in 1924. The inscription reads:

\section{[S]ex(tius) Pedani[us-] f(ilius) Seneca \\ Sex(tius) Pedanius, son, Seneca"}

Due to the damage of the right side of the plate filiation is not full preserved.

Pranenomen Sextius one of the most often used Roman names.

Nomen gentile Pedanius is relatively frequent, with province of Hispania being the place where it is most often used, second to it being Italy. ${ }^{138}$ It might be of Latin origin, since there are few people with the name Pedanius recorded in history, some as early as Second Punic War. ${ }^{\text {I39 }}$

Cognomen Seneca is of Latin origin. It is a cognomen which originated as a nickname denoting persons great age which was a common practice in Roman onomastics. ${ }^{140}$ Some authors hold that it might be of Celtic origin. ${ }^{14}$ This view is sometimes questioned or it is thought that the origin cannot be discerned unless the name appears in a predominately Celtic (e. g. Gaul) or Roman (e.

I3 8 Mócsy, Nomenclator provinciarum Europae Latinarum et Galliae Cisalpinae, 217; Lörincz, Onomasticon provinciarum Europae Latinarum, vol. III, I31

139 Smith, A Dictionary Of Greek And Roman Antiquities, I63.

I 40 Kajanto, The Latin Cognomina, 307.

I4I Alföldy, Die Personennamen in der Römischen Provinz Dalmatia, 293 g. Africa) area. ${ }^{142}$ It is also important to note that the names was the most popular in Hispania and then Italy. ${ }^{\mathrm{I} 3}$ Together with the nomen gentile, it is possible that this individual was from a western province, likely Hispania, where the Romanization has already taken place and the names familiar among both Romans and indigenous population were used.

There is a slight possibility that this is not a funerary monument.

The monument can be dated to late $\mathrm{I}^{\text {st }}$ century BC.

\section{A votive monument dedicated to Nemesis}

A small ara (lat. arula) made of limestone (Inscr. It. X. 3. 35). Right side is damaged (height: 0,54 $\mathrm{m}$, width: $0,25 \mathrm{~m}$, thickness: $0,25 \mathrm{~m}$ ). It was found in the village of S. Pietro dell'Amata, in the valley of Dragonja river. It was somehow brought to the Museum of Trieste by Marco Marcuzzo Villanovensi in I898. It is neither known where the monument was found nor who was the man who sold it to the Museum. It is kept in the lapidarium of the Trieste Museum. The inscription reads:
Nem[e]-
si
Aug(stae)
$\operatorname{sac}($ rum)
Qui[---]
servus L(uci)
[---]nicius
Protocteti
$[v($ otum $)] s$ (olvit) l(ibens)
"Dedicated to Nemesis the revered one,
Qui[ntus] slave of Lucius [--- nicius Proto-
ctetus, willingly and deservedly fulfilled his vow"
This is a votive monument dedicated to the goddess Nemesis, by a slave Quintus to his for-

\footnotetext{
I42 Kajanto, The Latin Cognomina, I7; Radoslav Katicic, "Zur Frage der keltischen und pannonischen Namengebiete im romischen Dalmatien", Godišnjak Centraza Balkanoloska ispitivanja IIl/I (1965), 59.

I 43 Lörincz, Onomasticon provinciarum Europae Latinarum, vol. IV, 65.
} mer master. 
Name of the dedicator is recorded only as $Q u$ intus, which was likely his single slave name. It is one of the 18 most often used Roman names.

The full name of the master for whom the monument was erected is not fully preserved with

only his praenomen and cognomen being recorded fully.

Praenomen Lucius is one of the most common Roman names.

His nomen gentile is only partially preserved and can only be guessed.

Cognomen Protoctetus is very rare and there are only three inscriptions where it is attested, two others being from Gallia Narbonensis. ${ }^{\text {I44 }}$ Entries in the databases reveal that this name is somewhat familiar in Italy and related to freedman. ${ }^{\text {I45 }}$ Its origin is uncertain, but might be Latin. However, it is suffice that he is recorded as a master of the the slave Quintus and because of that, likely a Roman citizen

The monument is dated to the ist half of the ist century AD.

\section{Funerary monuments to Lucius Sellius and Plautia Tertulla}

This monument (CIL V 502, Inscr. It. X. 3.22) survives only as drawing. It was seen by Orsato and Carli, but now it happens to be lost. The inscription reads:

L(ucio) Pa[...] Sellio

Plautiae Tertullae

[...] senif(ilio)

merentiposuit

"To Lucius Pa Sellius, to Plautia Tertulla, son, deserved made it

This funerary monument mentions three people in total, but only two have a preserved name in the inscription.

I44 Mócsy, Nomenclator provinciarum Europae Latinarum et Galliae Cisalpinae, 243; Lőrincz, Onomasticon provinciarum Europae Latinarum, vol. IV, 168.

I45 CIL III 157; CIL VI 1057; CIL VI 8578; CIL VI 9915; CIL VI 18181; CIL VI 20473; CIL VI 27443; CIL IX 3246; CIL XIV; AE 1920, o.105.
First is Lucius Sellius. His praenomen very common, but his nomen gentile is not fully preserved and can only be guessed. Despite that, the fact that his name was written in tria nomina formula means that he was a Roman citizen.

Cognomen Sellius is relatively often attested in Italy and might be of Latin origin. It is popular among former slaves, but more often as nomen gentile a than as cognomen. ${ }^{146}$

Plautia Tertulla, bearing a common name formula for woman was also a Roman citizen.

Name Plautia is a common Roman name and of Latin origin. Same can be said for Tertulla, which is a nickname derived from Tertia, which in turn derives from the pracitce of giving names in bigger families. ${ }^{147}$

Both Lucius Sellius and Plautia Tertulla being citizens with Roman names, it can be concluded that they might have immigrated to Aegida sometime during the first half of ist century AD.

\section{Stone slab with inscribed names}

This monument (Inscr. Inscr. It. X. 3. 17) is stone slab without a frame made in Aurisina limestone (height: $0,30 \mathrm{~m}$; Width: $0,31 \mathrm{~m}$; thickness: $0,13 \mathrm{~m}$ ). The slab is damaged and the letters are inscribed loosely and are worn. It was found in the atrium of the Museum of Koper where it is now kept. The inscription reads:

$$
\begin{aligned}
& \text { [---Co]rnelius } \\
& \text { [---]us } \\
& {[---] s} \\
& {[---] u[---]} \\
& \text { "[Co]rnelius" }
\end{aligned}
$$

The only word that can be dicserned is the name Cornelius. It is a true Roman name of Latin origin. This name was very popular and belongs to one of the oldest Roman names. Due to its popularity, it probably belonged to a Romanized member of Aegida, who was likely a citi-

I46 Mócsy, Nomenclator provinciarum Europae Latinarum et Galliae Cisalpinae, 259; Lörincz, Onomasticon provinciarum Europae Latinarum, vol. IV, 63

147 Matijašić, Uvod u latinsku epigrafiju,61-62. 
zen, maybe even an immigrant from other parts of Italy.

The monument is dated to Ist half of Ist century AD.

\section{Classification of inscriptions and monuments}

The inscriptions in this work can be classified into four categories based on its type: funerary, dedicatory, building inscription and document. Although the inscriptions are analyzed minutely in the text, short overview of types is presented.

Concerning the monuments, the majority of them were made in local Aurisina or some other Istrian limestone, like Grožnjan or local Koper stone. Only one monument, the bronze plate, was made from metal.

\section{Funerary inscriptions}

Funerary monuments make up the majority of inscriptions found in the Koper area and presented in this work. This fact is not suprising, since the vast majortiy all Roman inscriptions are of funerary character, especially outside of Rome and even more so in the provinces. The inscriptions found in Koper and its vicinity, don't stand out in any way and usually contain the information about the deceased, his family and sometimes the person who erected the monument.

One inscription (No. 2I) is a damaged monument which only mentions two people. Due to damage the inscription is only partially preserved and it is not known certainly whether it is of the funerary or maybe of some other character.

The funerary monuments themselves were made in few simple shapes: stele (inscribed plate), ara (rectangular altar, often for votive purposes), cippus (rectangular or any other geometrically shaped tombstone) and parts of the sacrophagus (coffin for the corpse of the deceased).

\section{Dedicatory inscriptions}

The nature of dedicatory inscriptions are often related to the happy fullfilment of the vow taken before some journey, bussiness or other venture, whi- ch ended favorably for the the person who then erected the monument to thank the gods and fulfill his part of the vow. This is further confirmed by the use of VSLM abbreviation. This type of monument is found all over the Empire and due to its popularity, it is not surprising for them to be found in the urban center like Aegida, although they are still significantly less represented than the funerary inscriptions.

Three inscriptions presented in this work are of votive character, all of which mention deities.

Monument dedicated to Silvanus Augustus (No. 2) was erected by Quintus Appuleius Epagathus, a freedman.

Another monument was erected by Quintus, slave of Lucius Protoctetus, who fullfilled the vow to goddess Nemesis (No. 22).

Only one monument (No. 2) found in Koper is dedicated to an oriental deity, in this case an Egyptian godess Isis. It was erected by Lucius Valerius Memor, who also served as sevir Augustalis, a priest of the imperial cult and by the information in the inscription, a distiguished member of the society in the 2 nd century AD.

\section{Building inscriptions}

This type of inscription often mentions an emperor or a magistrate who funded the construction work of some public building. This was a very common way of commemorating a donation for a public cause, so that the benefactor was known and not forgotten by the community to which he served.

One building inscription (No. 5) mentions a certain Sextius Brinniarius Certus. It also reveals that is a portico was built at the expense of the above mentioned citizen.

\section{Documents}

Documents (Latin acta) were a type of inscriptions which had legal importance and included treaties, laws but also calendars and military diplomas.

Bronze plate found in Arjol near Koper (No. 17) is a rare and important type of inscription for this area. It is probably a legal document which is 
Table s. Origin of names on the inscriptions from Koper

\begin{tabular}{|c|c|c|c|c|}
\hline Roman & Celtic & Greek and oriental & Indigenous & Uncertain \\
\hline Lucius Valerius Memor & S. Brinniarius Certus & Sal(via?) Nicostrata & Q. Cervius Fidelis & Calla or Galla \\
\hline Quintus & S. Pedanius Seneca? & C. Calpurnius Alexsa & Magaplinus & \\
\hline $\operatorname{Pup}($ inia) Forens[is] & & C. Lorentius Tesifon & Raecus & \\
\hline C. Titius & & $\begin{array}{l}\text { Q.Appuleius Epagat- } \\
\text { hus }\end{array}$ & P. Acisinus Venius & \\
\hline P. Aelio Victori & & L. Publicius Syntropus & P. Sardius Prudens & \\
\hline P. Aelius Quartus & & & & \\
\hline Pistor & & & & \\
\hline Flaminia & & & & \\
\hline Maesia & & & & \\
\hline C. Calpurnius Frugi & & & & \\
\hline Sabinnaeus & & & & \\
\hline Celotis Naevola? & & & & \\
\hline L. Herennius & 0 & & & \\
\hline L. Priscus & & & & \\
\hline C. Lorentius & & & & \\
\hline Lucida Dignitas & & & & \\
\hline Tullia Privata & & & & \\
\hline Tullia Septimina & & & & \\
\hline Marcella & & & & \\
\hline Maxima & & & & \\
\hline Tertia & & & & \\
\hline S. Pedanius Seneca? & & & & \\
\hline L. Protoctetus? & & & & \\
\hline Cornelius & & & & \\
\hline Baburia Plotia & & & & \\
\hline Tertulla & & & & \\
\hline Lucius Sellius & & & & \\
\hline
\end{tabular}

related to the granting of the citizenship to the indigenous family of Magaplines. ${ }^{148}$

\section{Classification of names mentioned in the inscriptions}

The names on the inscriptions found in Aegida were already a topic of research with published re-

I48 Starac, "Pitanje istočne granice Cisalpinske Galije i odnos općina Tergeste i Egida”, 3 I sults which indicate that the vast majority of names were Roman, ${ }^{149}$ so the following table gives only a broad overview of names which were analyzed in the article. It is important to point out that this table gives only a simple classification of names, while assumptions about social, legal and

I49 Starac, "Pitanje istočne granice Cisalpinske Galije i odnos općina Tergeste i Egida", 28-29. 
Table 2. Natural born citizens from Aegida

\begin{tabular}{|c|c|c|}
\hline Name & Monument & Datation \\
\hline Pup(inia) Forens[is] & Inscr. It.X.3.6; CIL V 487 & Ist century AD \\
\hline Sextius Brinniarius Certus & Inscr. It.X. 9. 6; CIL V 489 & Ist century BC- early ist century AD \\
\hline Publius Aelius Victor & Inscr. It.X.3.7; CIL V 492 & 2nd century AD \\
\hline Publius Aelius Victor & Inscr. It. X.3. 8; CIL V 493 & 2nd century AD \\
\hline Lucius Herennius & Inscr. It. X. 3. 19; CIL V 499 & Ist century AD \\
\hline Lucius Priscus & Inscr. It.X.3.19; CIL V 499 & Ist century AD \\
\hline Lucida Dignitas & Inscr. It.X.3.23; CIL V 504 & 3 rd century AD \\
\hline Tullia Privata & Inscr. It. X.3.23; CIL V 504 & 3 rd century AD \\
\hline Tullia Septimina & Inscr. It. X. $3.23 ; \mathrm{CIL} \mathrm{V}_{504}$ & 3 rd century AD \\
\hline Caius Titius & Inscr. It. X.3.31; CIL V 486 & early ist century AD \\
\hline Sextius Pedanius Seneca & Inscr. It.X. 3.34 & late ist century BC \\
\hline Cornelius & Inscr. Inscr. It. X. 3. 17 & Ist half of ist century AD \\
\hline Plautia Tertulla & Inscr. It. X.3.22, CIL V 502 & first half of ist century AD \\
\hline
\end{tabular}

geographical origin of the population is discussed further in the text.

\section{Socio-legal status of population on the basis of inscriptions}

Aboundance of information about social and legal status of the population of Aegida is available from the inscriptions analyzed in this work.

The population is divided into four socio-legal classes: natural born citizens, freedman and their descendants, former peregrines and slaves. It is important to point out that the majority of people mentioned in the inscriptions are citizens. This is confirmed mostly by the use of tria nomina naming system or by the information from the inscription itself, which reveals if the person was a former slave and gained the citizenship by the way of manumission. The high number of citizens reflects the legal status of the community and the level of Romanization the area achieved in the Principate, in some cases even in its early phases. ${ }^{150}$

I50 Starac, "Pitanje istočne granice Cisalpinske Galije i odnos općina Tergeste i Egida”, 29.

\section{Natural born citizens}

This category inculdes people who were born with citizenship but were not descendants of freedman. They are made up mostly of Romanized indigenous population who adopted Roman nomenclature, immigrants from other parts of Italy, people who were granted citizenship by municipal right or owners of the freed slaves only mentioned in the formula used to denote freedman. This socio-legal category of population is the most numerous on the inscriptions found in Koper and its vicinity.

People born with citizenship are recorded with their full name, tria nomina formula (which is not always preserved in the inscription due to damage) or other indications, such as tribal affiliation with a Roman cognomen.

The other category of inscriptions includes people who are just mentioned as owners of former slaves or whose name can be guessed on the basis of the freedmans praenomen and gentilicum: Quintus Appuleius (No. 2), Lucius Publicius (No. 4), Gaius Calpurnius Frugi (No. Io), Quintus Cervius (No. II), Gaius Lorentius (No. I4), Maxima, Marcella and Tertia (No. I7), Publius Sardius (No. 20) and Lucius Protoctetus 
Table 3. Names of freedman

\begin{tabular}{|c|c|c|}
\hline Name & Monument & Datation \\
\hline Lucius Valerius Memor & Inscr. It.X. 3. I; CIL V 484 & 2nd century AD \\
\hline Quintus Appuleius Epagathus & Inscr. It. X.3.2; CIL V 485 & Ist - 2nd century AD \\
\hline Lucius Publicius Syntropus & Inscr. It. X. 3. 6; CIL V 488 & mid ist century AD \\
\hline Sal(via?) Nicostrata & Inscr. It. X.3.8; CIL V 493 & 2nd century AD \\
\hline Titus Pistor, Flaminia, Maesia & Inscr. It.X. $3 \cdot 13$ & first half of the ist century AD \\
\hline Caius Calpurnius Alexsa & Inscr.It.X.3. I4; CIL V 495 & Ist century AD \\
\hline Sabinnaeus & Inscr.It.X.3. I4; CIL V 495 & Ist century AD \\
\hline Quintus Cervius Fidelis & Inscr. It. X. 3. 16; CIL V 496 & Ist century AD \\
\hline Caius Lorentius Tesifon & Inscr. It.X. $3.20 ;$ CIL V 500 & 3 rd century AD \\
\hline Magaplines & Inscr. It. X.3.30; CIL V 50I & Ist century AD \\
\hline Galla? & Inscr. It. X.3.32; CIL V 491 & Ist century AD \\
\hline Publius Sardius Prudens & Inscr. It.X.3.33; CIL V 503 & early ist century AD \\
\hline Celotis Naevola? & Inscr. It.X. 3. I8; CIL V 498 & ist AD \\
\hline
\end{tabular}

(No. 22). Although their names are not always recorded fully in tria nomina form, they must've been Roman citizens, otherwise they couldn't have owned slaves. It can be assumed that they owned land or ran bussinesses which were worked by slaves in the Aegida area.

\section{Freedman and their descendants}

This social group is the second most numeros class of citizens mentioned on the inscriptions. Freedman were the most mobile social class and their presence tell both about need for slave labor and the increasing number of citizens, which can be related to the rising of all aspects of urban structure of Aegida. Since they form a special social class, they are categorized separately from the natural born citizens, although their legal status and that of their descendats, is almost the same.

Almost half of inscriptions found in Koper and its vicinity mention a freedman.

\section{Former peregrines}

Only one inscription (No. 19) found in Koper can be ascribed to the former peregrine with some certainty. His name is Publius Acisinius
Venius, which is likely of Illyrian and therefore of indigenous origin. Along with the filiation of the father in the genitive case, which is very typical for peregrines, ${ }^{151}$ it can be conjectured that this individual was maybe a former peregrine.

Also, Publius Aelius Quartus (No. 7) might have been a descendant and therefore a freeborn citizen or a peregrine who was conferred citizenship by Hadrian.

\section{Slaves}

In the category of non-citizen population, only one inscription (No. 22) mentions a slave named Quintus, whose master is Lucius Protoctetus. It is interesting that the only inscription mentioning a slave is a votive dedication to Nemesis and that the mentioned slave has a true Roman name, unlike other slaves, whose names are mostly of oriental or Greek origin. It is possible that this particular individual was a Roman who lost his freedom due to debt or some other circumstance. Because of the lack of information, this assumption cannot be confirmed.

I5 I Julijana Visočnik, "Names on Celeian inscriptions in numbers and tables - a comparison between town and ager", Opuscula Archaeologica $34(2010), 232-233$. 
Other possible slave mentioned on the inscription from Aegida, might have been Galla, wife of Publius Acisinus Venius (No. 19), since she bears a single-part name. However, since her husband was a citizen, marriage could not have been legal if they both were not citizens, so it is also possible that Galla was a freedwoman, as already classified that way above.

\section{Geographical origin of population based on the origin of the name}

It is very hard to connect person to the geographical origin only on the basis of its name, especially if the that origin is not mentioned in the inscription with the usual formula which accompanies the foreigners (natione, domo or tribu which is certainly is assigned to some other community), their profession (e. g. soldiers) or a votive dedication which is certainly of foreign origin. ${ }^{152}$ In conjecture with the works of other authors, very broad outline of the geographic origin of population of Aegida can be discerned.

\section{Indigenous population}

Inscriptions which mention indigenous population are the most numerous in this classification and are already published as such by other authors. ${ }^{153}$ On the basis of their names (Cervius, Acisinus, Sardius, Magaplines, Raecus) which they received as freedman by their former masters, it can be conjecutred that the former owners also bore indigenous names, typical for Istria and in some cases Liburnia.

Because the onomastical studies in the Illyrian and Liburnian nomenclature were the topic of interest to a number of archeologists and linguists, it is relatively easy to pinpoint the origin of the population on the basis of their names in those areas. Outside of it, the area of possibility and uncertainty is entered, so only the broadest outline can be given.

152 Visočnik, "Names on Celeian inscriptions in numbers and tables", 277.

I53 Krahe, Lexikon Altillyrischer Personennemen, 28; Jürgen Untermann, Die Venetischen Personennamen, 17; Starac, "Pitanje istočne granice Cisalpinske Galije i odnos općina Tergeste i Egida”, 29.

\section{Italics}

Inscriptions which mention population of possibly Italic origin are hard to determine and are likely connected to the owners of former slaves. If the gentilicium is not of indigenous of Imperial origin, it is likely Itallic and related to colonists who owned land or were immigrants, in this case from other parts of Italy ${ }^{154}$ who bore true Roman names: member of the Pupinia tribe and cognome Forensis (No. 3), Gaius Calpurnius Frugi (No. Io) Maxima, Marcella and Tertia(No. 17) and maybe Lucida Dignitas (No. 15), Baburia Plotia and the Taronians (No. 8). The owners whose name was given to the freedman is not included in Table 4.

\section{Orientals}

Although most slaves have a name of oriental or Greek origin, studies have found that this alone cannot be a sign of their geographical provenance. ${ }^{155}$ Slaves from the western parts of the Empire also were given Greek names and it seems that this practice was common for the whole social class. On the inscriptions from Koper (No. 4 and I4), it can be assumed that two people were maybe from the East or Africa.

Lucius Publicius Syntropus (No. 4) was likely of oriental origin, although he bears a gentilicum very often found in the Istria and the Cisalpine Gaul. This assumption is made on the basis of the cognomen he bore, which is of Greek origin, his status as a freedman and the function of archigallus, which is a priestly service of Magna Mater. Due to its oriental provenance and populatiry in the East, it is possible that Lucius Publicius Syntropus came from the East as a slave, was manumitted and then served as a priest in the oriental cult.

Second inscription mentions Caius Lorentius Tesifon (No. I4), who might have been brought as a prisoner during the campaign of Septimius Severus against the Parthians in 197 AD. Although this seems as sa far-fetched assumtpion, the name and the datation of the monument open this possibility.

\footnotetext{
I54 Visočnik, "Names on Celeian inscriptions in numbers and tables", 232.

I55 Matijašić, Uvod u latinsku epigrafiju, 62.
}

$\sqrt{2}$

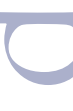

O

\author{
$f$
}

\section{(} (a) 
Table 4. Names divided on the basis of their possible geographical origin

\begin{tabular}{|c|c|c|c|}
\hline Indigenous & Italic & Oriental & Western \\
\hline Quintus Cervius & Pup(inia) Forens[is] & Lucius Publicius Syntropus & Sextius Brinniarius Certus \\
\hline Magaplines & Gaius Calpurnius Frugi & Caius Lorentius Tesifon & Sextius Pedanius Seneca? \\
\hline Publius Sardius Prudens & Lucida Dignitas? & & Caius Titius \\
\hline Raecus & Cornelius & & Lucius Valerius Memor \\
\hline Maxima, Marcella Tertia & $\begin{array}{l}\text { Baburia Plotia } \\
\text { Plotianus } \\
\text { Iuliane }\end{array}$ & & \\
\hline
\end{tabular}

\section{Westerners}

Similar as with the orientals, it is very hard to determine the geographical origin of the people who bear names mentioned only in the west. They might or might not have been from the far western areas of the Empire, since Celtic names which they usually have, were very popular in surrounding areas like Northern Italy and Noricum.

Lucius Valerius Memor (No. I), Sextius Brinniarius Certus (No.s) and maybe Sextius Pedanius Seneca (No. 2I) offer a possibility that the persons mentioned were maybe of Celtic or western origin.

Only one inscription (No. 18) found in Koper is undoubtly of western and Celtic provenance. It is the funerary monument of Caius Titius, a legionnaire from Vienna in Gaul, who explicitlyhstates this fact in the inscription. He served in Is legion of Appolonians and probably after his service, retired in vicinity of Koper like his other comrades.

\section{Conclusion}

Onomastical analysis of inscriptions found in Koper and its vicinity reveal that ancient Aegida was a romanized urban community, situated on the island where today historical center of Koper stands. While relativley numerous compared to size and apparent importance during the antiquity, due to renaissance and humanistic habit of collecting and transfering Roman monuments, the information gained from the analysis can prove problematic and unreliable. It has been pointed out that there is no solid proof that any of the monuments were found in the archaeological context or on the island itself. However, a very broad outline can be discerned if the fact that Aegida was a town with the municipial status at least from the time of Augustus and that the monuments are related to its population, and not to that of nearby Tergeste.

The types of inscriptions fall into four basic categories, sorted by their numbers: funerary, dedicatory, building inscriptions and documents.

The most important fact that stems from the onomastical analysis of inscriptions is the number of Roman names and the number of citizens, both natural-born and freedman. These two categories of onomastical and social aspects reveal that the population was already quite romanized already in the Early Principate. While not new, ${ }^{156}$ this conclusion cannot be overlooked in any work concerning ancient Aegida.

Roman names are the most numerous and make up the majority of all names inscribed in the inscriptions. Other categories of names include those of Greek or oriental origin, Celtic, indigenous and of unknown origin. It is important to point out that indigenous names were often borne by freedman, which is important because they inherited them from their masters. Landowners of bussinessman who were citizens, but were still named in their native fashi-

I56 Starac, "Pitanje istočne granice Cisalpinske Galije i odnos općina Tergeste i Egida”, 28. 
on, further contributes to the fact that the Romanization was quick and effective.

Concerning the socio-legal picture of the population of Aegida, citizens which are made of natural born and freedman are the most numerous social group, with peregrines and slaves being almost nonexistant on the inscriptions. However, this can be a misleading and cannot mean they were not represented in the population, especially if the number of freedman is taken into consideration.

The mobility of the social hierarchy is also witnessed by the magistracies mentioned in the inscriptions, which are considered to belong to the political subjects of Aegida, and not Tergeste.

While being very hard to pinpoint excatly, a short oveview of the geographical provenance of people mentioned in the inscriptions can be discerned. These include indigenous population and Italics who were probably landowners and immigrants. While being relaitvely numerous, freedman with oriental and Greek names, cannot immediately be held to come from the East. Only two indviduals were likely of oriental origin. The last group includes the population which probably came or were native to the areas in the West (Hispania and Gaul). Only one individual is certainly from Gaul, as it is stated in his monument. His inscription is also the only one mentiabing a profession, in this case a legionnaire of is legion of Appolonians.

Although Aegida seems to have lost its importance as it did not appear in the maps, itineraries and historical sources, inscriptions from the period of Principate reveal that it was an urban community with vibrant social structure who quickly adopted the Roman way of life, which is reflected in their names on the monuments they erected, both of which are important signs of Romanization.

\section{Povzetek}

Članek ponuja onomastično analizo štiriindvajsetih napisov, ki so bili izkopani v Kopru ali v njegovi bližini. Vsi napisi so že objavljeni v ustreznih korpusih latinskih besedil. Z onomastično analizo epigrafskih spomenikov in napisov članek zbira razpoložljive podatke o socialno-pravnem statusu in možnem geografskem poreklu prebivalstva v stari Egidi (današnjem Kopru). Ti spomeniki dokazujejo, da so območje v okolici Egide naseljevali rimski državljani, osvobojenci, sužnji in priseljenci. Izvor ljudi, navedenih v napisih, kaže na pripadnike avtohtonega prebivalstva, ki so bili do neke mere romanizirani, a tudi na prebivalce z vzhoda, zahoda in priseljence iz drugih delov Italije. Med temi so tudi razni posamezniki, ki so opravljali razne drževne funkcije. Predstavljene so tudi kratka zgodovina Egide in okoliščine odkritja spomenikov. Vsi napisi iz obdobja principata.

\section{Summary}

The article gives an onomastical analysis of twenty-four inscritpions found in or in the vicinity of Koper, all of which are already published in the relevant corpora of Latin texts. Thorugh the onomastical analysis of epigraphical monuments and inscriptions, article discernes available information about socio-legal status and the possible geographical origin of the population in ancient Aegida (todays Koper). These monuments reveal that freeborn citizens, freedman, slaves and peregrines inhabited the region around Aegida in antiquity. Origin of the people mentioned in the inscriptions include indigenous population romanized to certain extent, orientals, westerners and immigrants from other parts of Italy. There are also several individuals who are recorded to have preformed certain magistracies. Short history of Aegida and the nature of finding of monuments is also presented. All inscriptions are dated to the period of the Principate.

\section{Bibliography}

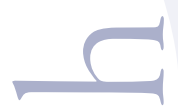

Alföldy, Geza. Die Personennamen in Der Römischen Provinz Dalmatia. Heidelberg: Winter, 1969.

Bodel, John P. Roman Brick Stamps in the Kelsey Museum. Ann Arbor: University of Michigan Press, 1983.

Cunja, Radovan. "Koper, Kapucinski vrt.” Arbeološki pregled (1986) 1987, I18-120.

Degrassi, Attilio. Abitati Preistorici E Romani Nell'agro Di Capodistria E Il Sito Dell'antica Egida. Parenzo: G. Coana e Figli, 1933. 
Degrassi, Attilio. Inscriptiones Italiae, Vol. X., Regio X, Fasc. III. Roma: Libreria Dello Stato, 1936.

Farnum, Jerome H. The Positioning of the Roman Imperial Legions. Oxford: Archaeopress, 2005.

Glavičić, Miroslav. "Tri rimskodobna natpisa iz Senja." Senjski zbornik 23 (1996), 19-34.

Hornblower, Simon. The Oxford Classical Dictionary. 3rd ed. Oxford: Oxford University Press,

1996.

Kajanto, Iiro. The Latin Cognomina. Societas Scientiarum Fennica, Commentationes $\mathrm{Hu}$ manarum Litterarum, XXXVI 2: Helsinki 1965.

Katičić, Radoslav. "Zur Frage der keltischen und pannonischen Namengebiete im romischen Dalmatien." Godišnjak Centra za Balkanološka ispitivanja III (1965), 53-76.

Karković Takalić, Palma. "Period of Introduction and Role of Archigalli in Context of the Inscription of L. Publicius Syntropus from Koper. "Archaeologia Adriatica 6 (20I2): 87-105.

Keppie, Lawrence J. F. Understanding Roman Inscriptions. Baltimore: Johns Hopkins University Press, 1991.

Krahe, Hans. Lexikon Altillyrischer Personennemen. Heidelberg: Carl Winter's Universitätsbuchhandlung, I929.

Križman, Mate, Rimska imena u Istri: osobna imena na istarskim natpisima iz rimskog doba. Zagreb: Latina Et Graeca, 1991.

Lörincz, Barnabas, Redö, Ferenc. Onomasticon provinciarum Europae latinarum: Aba-Bysanus, vol. I. Budapest: Archaeolingua Alapítvány, 1994.

Lörincz, Barnabas. Onomasticon provinciarum Europae Latinarum, vol. II: CABALICIUS-IXUS. Wien: Forschunsgesellschaft Wiener Stadtarchäologie, 1999.

Lörincz, Barnabas. Onomasticon provinciarum Europae Latinarum, vol. III: LABAREVS-PYTHEA. Wien: Forschunsgesellschaft Wiener Stadtarchäologie, 2000.
Lörincz, Barnabas, Onomasticon provinciarum Europae Latinarum, vol. IV: QVADRATIA-ZVRES, Wien: Forschunsgesellschaft Wiener Stadtarchäologie, 2002.

Mainardis, Fulvia, E ora sono tutti Romani. L'evoluzione delle formule onomastiche nelle iscrizioni della Transpadanaromana. Roma, 1997. Matijašić, Robert. Uvod u latinsku epigrafju. Pula: Filozofski fakultet u Puli, 2002.

Mócsy, Andras, Pannonia and Upper Moesia: A History of the Middle Danube Provinces of the Roman Empire. London; Boston: Routledge and K. Paul, 1974.

Mócsy, Andras, Feldmann, Reinhard. Nomenclator Provinciarum Europae latinarum et Galliae Cisalpinae: cum indice inverso. Budapest: Népművelési Propaganda Iroda, 1983.

Perinić, Ljubica. "O zavjetnom natpisu Minervi "Opuscula Archaeologica 23-24 (2000), 417424.

Ritterling, Emil. "Legio" in RE XII, II86 - I829. Stuttgart: J. B. Metzler, 1924-1925.

Rossignano, Maria Silvia. "I Praefecti iure dicundo nell'Italia settentrionale." in Epigrafia. Actes du colloque international d'epigraphie latine en mémoire de Attilio Degrassi pour le centenaire de

sa naissance. Actes de colloque de Rome (27-28 May 1988) (Rome: École Française de Rome, 199I), 515-537.

Salway, Bennet. "What's in a Name? A Survey of Roman Onomastic Practice from c. 700 B.C. to A.D. 700." Journal of Roman Studies 84 (1994): I24-I45.

Schulze, Wilhelm. Zur Geschichte lateinischer Eigennamen. Berlin; Zürich; Dublin: Weidmann 1966.

Smith William, Wayte William, ed., G. E Marindin. A Dictionary Of Greek And Roman Antiquities. London:John Murray I8go.

Suić, Mate. Anticki grad na istočnom Jadranu. Zagreb: Sveučilisna naklada Liber, 1976.

Starac, Alka. "Pitanje istočne granice Cisalpinske Galije i odnos općina Tergeste i Egida." Histria Archaeologica 24-25 (1993 - 1994): 5-57. 
Šašel, Jaroslav, Weiler, Ingomar. "Zur augusteisch-tiberischen Inschrift von Emona", Carnuntum Jabrbuch 8 (1963-1964), 40-42.

Šašel, Jaroslav. "Koper." Arheološki vestnik 25 (1976): 446-460.

Šašel, Jaroslav. "Zur Frühgeschichte der XV. Legion und zur Nordostgrenze der Cisalpina zur Zeit Caesars.” Archäeologisch-epigraphische Studien I (1985): 547-555.

Šašel-Kos, Marjeta. "The Isth Legion at Emonasome Thoughts." Zeitschrift für Papyrologie und Epigraphik Io9 (1995): 227-244.

Taylor, Lily Ross. "Augustales, Seviri Augustales, and Seviri: A Chronological Study." Transactions and Proceedings of the American Philological Association (1914), 231-253.

Untermann, Jürgen. Die Venetischen Personennamen. Wiesbaden: Harrassowitz, 196I.

Visočnik, Julijana. "Names on Celeian inscriptions in numbers and tables - a comparison between town and ager." Opuscula Archaeologica 34 (2010).

Wilkes, John J. The Illyrians. Cambridge: Blackwell, 1992.

Wheeler, Everett L. "Legio XV Apollinaris: From Carnuntum to Satala and beyond." in Y. Le Bohec, ed., Les Légions de Rome sous le Haut-Empire (Lyon/Paris: De Boccard, 2000), 259-30.

Župančič, Matej. "Inter utrumque tuta" in $\mathrm{Ko}$ per zwishen Rom und Venedig, ed. Matej Župančič (Koper: Regionalmuseum Koper, I991) 6-II.

Župančič, Matej. "Sermin ob Rižani, pretres virov in arheoloskih podatkov." Arheoloski vestnik 36 (1985): 315-325.

\section{List of sources}

\section{Cassius Dio}

Dio's Rome: An Historical Narrative Originally Composed in Greek during the Reigns of Septimus Severus, Geta and Caracalla, Macrinus, Elagabalus and Alexander Severus: And Now
Presented in English Form, trans. H. B. Foster, J.Zonaras. New York, 1905.

Pliny the Elder

Pliny's Natural History, trans. H. Rackham, W.H.S. Jones, D.E. Eichholz. Cambridge: Harvard University Press, London: William Heinemann 1949-1954.

Ravenna Cosmography

Ravennatis Anonymi Cosmographia et Guidonis Geographica, ed. Joseph Schnetz, Marianne Zumschlinge. Stuttgart: Teubner, 1990.
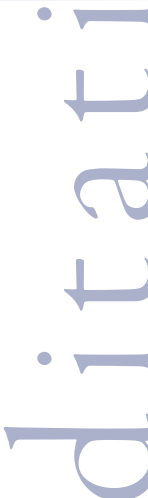

(
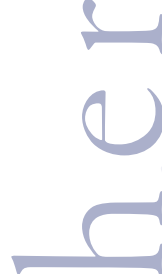


\section{NAVODILA ZA AVTORJE}

Revija objavlja primarno v slovenskem jeziku, toda tudi v večjih svetovnih jezikih (angleščina, nemščina, francoščina, ruščina). V objavo se sprejmejo tudi članki v cirilici. V primeru tujejezičnega članka morata biti izvleček in povzetek poleg angleščine obvezno v slovenskem jeziku. Za oboje poskrbi avtor.

Članek (praviloma v obsegu 7000 , vendar največ 10.000 besed) naj ima na začetku: I) naslov ter ime in priimek avtorja/-ice; 2) izvleček $\mathrm{v}$ slovenskem in abstract angleškem jeziku, do 250 besed; 3) ključne besede $\mathrm{v}$ slovenščini in angleščini (do 5); 4) kratko predstavitev avtorja/-ice (do roo besed v slovenščini in angleščini), navedena naj bo tudi organizacija zaposlitve. Članek naj po razpravnem besedilu vsebuje še: I) povzetek v slovenščini in angleščini ter 2) seznam virov in literature.

Prispevki naj bodo napisani v knjižni slovenščini (ali v knjižni različici katerega tujih jezikov, v kolikor gre za tujejezično delo) ob upoštevanju veljavnega pravopisa, $v$ nasprotnem primeru si uredništvo pridržuje pravico, da članka ne recenzira oziroma ga zavrne.

Če je prispevek že bil objavljen v kaki drugi reviji ali če čaka na objavo, je treba to izrecno navesti.

Prispevek naj ima dvojni medvrstični razmik, tip črk naj bo Times New Roman, velikost 12 pik (v opombah ıo). Besedilo naj bo levo poravnano, strani pa zaporedno oštevilčene. Odstavki naj bodo ločeni s prazno vrstico.

Uporabiti je mogoče do tri hierarhične nivoje podnaslovov, ki naj bodo oštevilčeni (uporabljajte izključno navaden slog, v prelomu bodo ravni ločene tipografsko): I. - I.I - -I.I.I

Za poudarke uporabite izključno ležeči tisk(v primeru jezikoslovnih besedil, kjer so primeri praviloma v ležečem tisku, lahko za poudarke izjemoma uporabite polkrepki tisk). Ležeče pišite tudi besede v tujih jezikih. Raba drugih tipografskih rezov (podčrtano, velike male črke, krepko kurzivno ...) ni dovoljena. Ne uporabljajte dvojnih presledkov, prav tako ne uporabljajte preslednice za poravnavo besedila. Edina oblika odstavka, ki je dovoljena, je odstavek z levo poravnavo brez rabe tabulatorjev prve ali katerekoli druge vrstice $v$ ostavku (ne uporabljajte sredinske, obojestranske ali desne poravnave odstavkov). Oglate oklepaje uporabljajte izključno za fonetične zapise oz. zapise izgovarjave. Tri pike so stične le, če označujejo prekinjeno bese... Pri nedokončani misli so tri pike nestične in nedeljive ... Prosimo, da izključite funkcijo deljenja besed.

Sprotne opombe naj bodo samooštevilčene (številke so levostično za besedo ali ločilom - če besedi, na katero se opomba nanaša, sledi ločilo) in uvrščene na tekočo stran besedila.

Citati v besedilu naj bodo označeni z dvojnimi (» «), citati znotraj citatov pa z enojnimi (") narekovaji. Izpuste iz citatov in prilagoditve označite s tropičjem znotraj poševnic /.../. Daljše citate (več kot 5 vrstic) izločite v samostojne odstavke, ki jih od ostalega besedila ločite z izpustom vrstice in umikom v desno. Vir citata označite v okroglem oklepaju na koncu citata. Če je avtor/-ica naveden/-a v sobesedilu, priimek lahko izpustite.
V besedilu označite najprimernejša mesta za likovno opremo (tabele, slike, skice, grafikone itd.) po zgledu: [Tabela i približno tukaj]. Posamezne enote opreme priložite vsako v posebni datoteki (v.eps, .ai, tif ali.jpg formatu, minimalna resolucija $300 \mathrm{dpi}$, tabele prilagajte $v$ posebni datotetki v formatu .doc, grafe pa v formatu.xls, kjer naj ob grafu stoji tabela, ki je podlaga za graf). Naslov tabele je nad tabelo, naslov grafa/slike pa pod grafom/sliko.

Prostor, ki ga oprema v prispevku zasede, se šteje v obseg besedila, bodisi kot 250 besed (pol strani) ali 500 besed (cela stran).

Ob oddaji preda avtor uredništvu članek v formatu doc in hkrati tudi.pdf.

Za citiranje literature in za pripravo seznama uporabljene literature se uporablja izkljućno stil Chicago, in sicer v obliki, kot je aktualna, tj.v svoji I6. izdaji (http://www.chicagomanualofstyle.org/home.html, I6. izdaja na razpolago na zahtevo tudi pri uredniku izdaje)

I: Enoavtorska monografija

a) Polna oblika reference pod črto: Michael Pollan, The Omnivore's Dilemma: A Natural History of Four Meals (New York: Penguin, 2006), 99-100.

b) Kratka oblika reference pod črto: Pollan, Omnivore’s Dilemma, 3 .

c) Navedba v virih in literaturi: Pollan, Michael. The Omnivore's

Dilemma: A Natural History of Four Meals. New York: Penguin, 2006. II: Većavtorska monografija

a) Polna oblika reference pod črto: Geoffrey C. Ward and Ken Burns, The War: An Intimate History, 1941-1945 (New York: Knopf, 2007), 52

b) Navedba v virih in literaturi: Ward, Geoffrey C., and Ken Burns. The War: An Intimate History, 1941-1945. New York: Knopf, 2007.

III: Knjiga z urednikom

a) Polna oblika reference pod črto: Joel Greenberg, ed., Of Prairie, Woods, and Water: Two Centuries of Chicago Nature Writing (Chicago: University of Chicago Press, 2008), 42.

b) Kratka oblika reference pod crrto: Greenberg, Prairie, Woods, and Water, 326-27.

c) Navedba v virih in literature: Greenberg, Joel, ed. Of Prairie,

Woods, and Water: Two Centuries of Chicago Nature Writing. Chicago:

University of Chicago Press, 2008.

IV: Poglavje v knjigi

a) Polna oblika reference pod črto: Glenn Gould, "Streisand as Schwarzkopf," in The Glenn Gould Reader, ur. Tim Page (New York: Vintage, 1984),310.

b) Kratka oblika reference pod črto: Gould, "Streisand as Schwarzkopf", 309 .

c) Navedba v virih in literaturi: Gould, Glenn. "Streisand as Schwarzkopf." In The Glenn Gould Reader, ur. Tim Page, 308-II. New York: Vintage, 1984.

Gould, "Streisand as Schwarzkopf," 309.
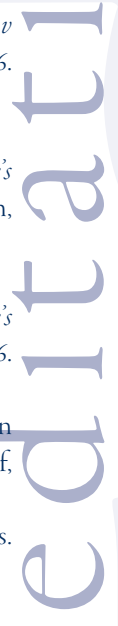
V: Clanek v reviji

a) Polna oblika reference pod črto: Walter Blair, "Americanized Comic Braggarts," Critical Inquiry 4, no. 2 (1977):331-32.

b) Kratka oblika reference pod črto: Blair, "Americanized Comic Braggarts," 335 .

c) Navedba v virih in literaturi: Blair, Walter. "Americanized Comic Braggarts." Critical Inquiry 4, no. 2 (1977): 331-49.

VI: Clanek v reviji (digitalna objava; DOI)

a) Polna oblika reference pod črto: William J. Novak, "The Myth of the 'Weak' American State," American Historical Review I13 (June 2008): 758 , doi:10.1086/ahr.113.3.752.

b) Kratka oblika reference pod črto: Novak, "Myth," 770 .

c) Navedba v virih in literaturi: Novak, William J. "The Myth of the 'Weak' American State." American Historical Review II3 (June 2008): 752--72. doi:10.1086/ahr.113.3.752., "Streisand as Schwarzkopf", 309.

VII: Članek v reviji (digitalna objava, URL)

a) Polna oblika reference pod črto: Wilfried Karmaus and John F. Riebow, "Storage of Serum in Plastic and Glass Containers May Alter the Serum Concentration of Polychlorinated Biphenyls," Environmental Health Perspectives II2 (May 2004): 645, http://www. jstor.org/stable/3435987 (datum dostopa do spletne strani).

b) Navedba v virih in literaturi: Karmaus, Wilfried, and John F. Riebow. "Storage of Serum in Plastic and Glass Containers May Alter the Serum Concentration of Polychlorinated Biphenyls." Environmental Health Perspectives 112 (May 2004): 643--47. http:// www.jstor.org/stable/3435987.

O morebitnih drugih posebnostih se posvetujte z uredništvom.

Naslov uredništva: dr. Gregor Pobežin, Fakulteta za humanistične študije Univerze na Primorskem, Titov trg 5,

SI-600o Koper, gregor.pobezin@fhs.upr.si 

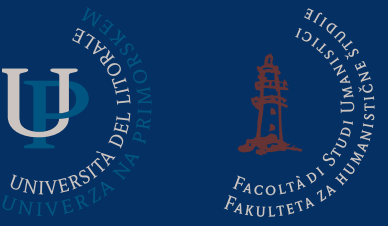

Založba Univerze na Primorskem www.hippocampus.si ISSN 2350-5443

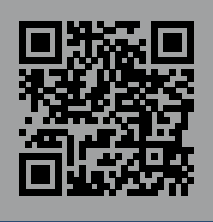

